\title{
Wooden Well at the First Farmers' Settlement Area in Uničov, Czech Republic
}

\author{
Studna s dřevěnou konstrukcí z osady prvních zemědělců v Uničově, \\ Česká republika
}

\author{
Ivana Vostrovská - Jan Petřík - Libor Petr - Petr Kočár - Romana Kočárová - \\ Zbyněk Hradílek - Josef Kašák - Zdeňka Sůvová - Katarína Adameková - Zdeněk Vaněček - \\ Jaroslav Peška - Bernhard Muigg - Michal Rybníček - Tomáš Kolář - Willy Tegel - \\ Marek Kalábek - Pavlína Kalábková
}

Redakci předloženo v prosinci 2019, upravená verze v dubnu 2020

\begin{abstract}
Some of the most extraordinary finds from the Early Neolithic period are wooden wells. These constructions permit unusual insights into Neolithic settlements, their subsistence and environment, as well as into the surrounding landscape. A recent excavation of a Neolithic settlement at Uničov in central Moravia, Czech Republic, yielded the discovery of a wooden well with a sediment infill from the beginning of the Neolithic period and allowed to study an array of topics by a multi-proxy approach using a set of complementary methods. Our study of the wooden lining demonstrates the carpeting skills of the first farmers, required also for building so-called 'longhouses'. By comparing dendrochronological and radiocarbon dating, we estimated the time span of the well's existence. The construction was used repeatedly over a longer time and was finally filled in intentionally. Studies of the well's infill shed light on its usage and decline, providing a great proxy for the study of living dynamics and handling of waste in a Neolithic village. The environmental record extracted from botanical residues indicates that the immediate surroundings of the settlement were covered by an open-canopy woodland with a dominance of oak and hazel, and a large proportion of open habitats, whereas the surrounding landscape was not noticeably affected by humans.
\end{abstract}

Wooden well, past environment, subsistence strategy, Linearbandkeramik, Uničov, eastern Central Europe

Jedním z nejpozoruhodnějších nálezů ze starého neolitu jsou studny s dřevěnou konstrukcí. Tyto objekty umožňují neobvyklý vhled do neolitických osad, na strategie obživy a prostředí, jakož i na okolní krajinu. Nedávný výzkum neolitického sídliště v Uničově na střední Moravě $v$ České republice přinesl objev dřevěné studny s výplní z počátku neolitu a umožnil studovat toto téma multi-proxy př́stupem za použití sady metod. Prezentovaná studie o dřevěné konstrukci demonstruje tesařské dovednosti prvních zemědělců, potřebné také pro stavbu tzv. dlouhých domů. Porovnáním dendrochronologických a radiokarbonových dat jsme odhadli časové rozpětí existence studny. Objekt byl používán opakovaně po delší dobu a nakonec byl záměrně zaplněn. Studie výplně studny osvětlily její využití a zánik, což je skvělým prostředkem pro studium dynamiky života a nakládání s odpady $v$ neolitické osadě. $Z$ environmentálního záznamu získaného $z$ botanických zbytků vyplývá, že bezprostřední okolí osady bylo pokryto lesem s otevřeným zápojem s dominancí dubu a lísky a velkým podílem otevřených stanovišt, zatímco okolní krajina nebyla lidmi znatelně ovlivněna.

Studna s dřevěnou konstrukcí, minulé prostředí, strategie obživy, kultura s lineární keramikou, Uničov, středovýchodní Evropa

\section{Introduction}

Hunter-gatherer communities in the Near East were able to consolidate and spread the farming lifestyles that led to the exponential population growth humans have maintained since Neolithic times, more than 10,000 years ago. Even though water has retained many of its wild and free characteristics, we should consider it a domesticated natural resource, since its natural properties have been constrained and manipulated to cater for human need (Mithen 2010, 5250). Neolithic water subsistence is characterized by active behaviour to secure and optimize the biotic and abiotic conditions by which food and other water-dependent products were made available. For this reason, the role of water management increased, entailing the planning, development, distribution and managed usage of water resources. Storage and land-use are the key socio-economic sectors in which new water techniques influence, trigger and protect new modes in sedentary life. It is specially the storage aspect that makes water a subject of domestication, not to mention the "neolithization of water' (Gebel 2004). Securing a sustainable water source was an important part of the construction of 


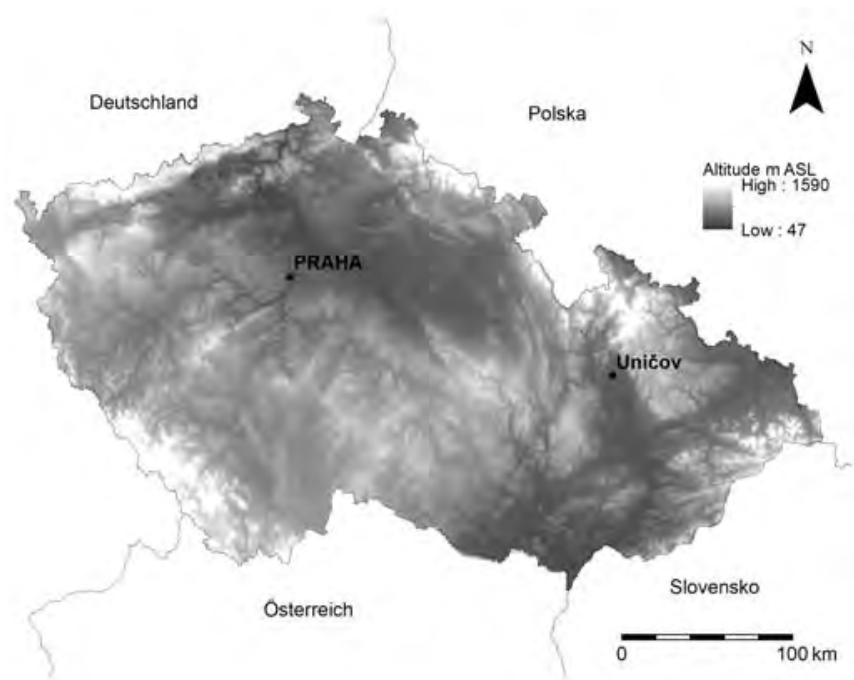

Fig. 1. Geographical site position. - Obr. 1. Geografická poloha lokality.

every new settlement. The active digging of permanent wells reaching the underground water table reflects an innovative approach to water provisioning in the first farmers' communities. Such wells provided them with their own water supply, so they did not have to rely solely on local rainfall. Water in a well is isolated and controlled, unlike water in a river, which is open to pollution by humans or animals. Finally, a well could have functioned as a status symbol, indicating the superiority of certain parts of the site over others. It is a testimony to the hydrological knowledge and technological capacities of the first farmers (Garfinkel - VeredBar-Yosef 2006).

Around the mid- $6^{\text {th }}$ millennium $\mathrm{BC}$, the transition to the Neolithic way of life took place in the Middle Danube region (Bánffy - Oross 2010), and over 100-200 years the new way of life spread to eastern Romania and through Central Europe to eastern Belgium. This brought the onset of what we now refer to as the Linear Pottery culture (Linearbandkeramik, LBK), which has been dated for the region of eastern Central Europe to the period of 5500-4950 BC (Kuča et al. 2012), especially ca 5400-4800 $\mathrm{BC}^{1}$ (Manning et al. 2014, 1077). The uniformity of architecture, artifacts, burials, subsistence and settlement plans that characterized these communities is extraordinary and represents a further extension of the Neolithic way of life. The sedentary way of life was related to plant cultivation and livestock breeding, and, as a result, people lived in larger groups and constructed permanent settlements (Price 2000; Barker 2011).

In Czechia, Neolithic wooden wells have so far been found only rarely. The first of the Neolithic wells with a preserved wooden lining dated to the LBK was found at the settlement by the town of Mohelnice in Moravia in 1970 (Tichý 1972). One more well was excavated by

\footnotetext{
1 The study area encompasses Central and Northwest Europe. Beginning and end dates estimated using the three different methods, accompanied by the mean and standard deviation using an improved normally distributed model.
}

the town of Most in northwest Bohemia in 1976 (RulfVelímský 1993) and another was discovered in 2007 in the Bohunice district of the city of Brno (Přichystal 2008). Neither of them yielded any evidence of any wooden lining. Over the past five years, three more wells were uncovered, all with a wooden lining: Uničov in Moravia in 2015 (Fig. 1; Kalábek 2016), Velim in central Bohemia in 2016 (Chlup 2017) and Ostrov in eastern Bohemia in 2018 (Sedláček et al. 2019). More than 100 wells from 53 Early Neolithic sites have been documented throughout Europe (Fig. 2). To date, the largest number of wells have been recorded in Saxony, SaxonyAnhalt and the Rhineland, where more than half the wells discovered have been investigated closely (Windl 1998; Zimmermann 2009; Tegel et al. 2012; Füzesi et al. 2015; Király - Tóth 2015; Kretschmer et al. 2016; Weiner 2016; Fülöp et al. 2018; Stäuble 2018, 78). Several European LBK wells have been described in great detail (Weiner 1994; Koschik 1998; Herbig et al. 2012/2013; Zerl - Herbig 2012; Tinapp - Schneider - Stäuble 2013; Stäuble - Veit 2016; Friederich 2017). On the other hand, out of the total number of six water wells in the Czech Republic, none has been evaluated and published in detail. However, there are some chronologically younger wells which have been analysed with a multiproxy approach that resulted in local landscape reconstruction. The wooden construction of the well and its infilling is the extraordinary evidence from the Roman period at Dražkovice in eastern Bohemia (Sedláček et al. 2008) and at Hurbanovo in southwest Slovakia (Hajnalová et al. 2018). From the Migration period, the excavation at Hostivice in the western district of the city of Prague in 2002 allowed the investigation of a settlement and a group of contemporary wells with wooden structures (Pleinerová 2005).

Water wells and their sedimentary infill are prehistoric archives of proxy data. They can provide informations about water treatment and timberwork and about the subsistence of the first farmers, which was very different from that of previous Mesolithic hunters and gatherers. It has been proved that they adhered to intensive garden cultivation and herding. A functional interdependence exists between crops and animal husbandry, as crop products and by-products were used as fodder. Available evidence of livestock breeding by the first farmers within the loess belt, again, suggests small-scale intensive management (Bogaard 2005). Their diet was based on crops such as einkorn wheat, emmer wheat and some other plants such as pea, lentil and opium poppy (Kreuz et al. 2005; Salavert 2011), and herded cattle and pigs (Hachem 2018). The results of macroremains analyses are important for understanding the post-glacial migration of plant species. Numerous present-day ruderal plant species are considered archaeophytes (Pyšek et al. 2012; Pokorná et al. 2018), which are believed to have migrated during the neolithization process, or later. But their origins and length of presence in our region are uncertain.

However, this environmental material does not only testify as to the subsistence strategy of the first farmers, but also as to the environment and vegetation. Among others, detailed reconstruction of the environment contributes to the unravelling of the genesis and 


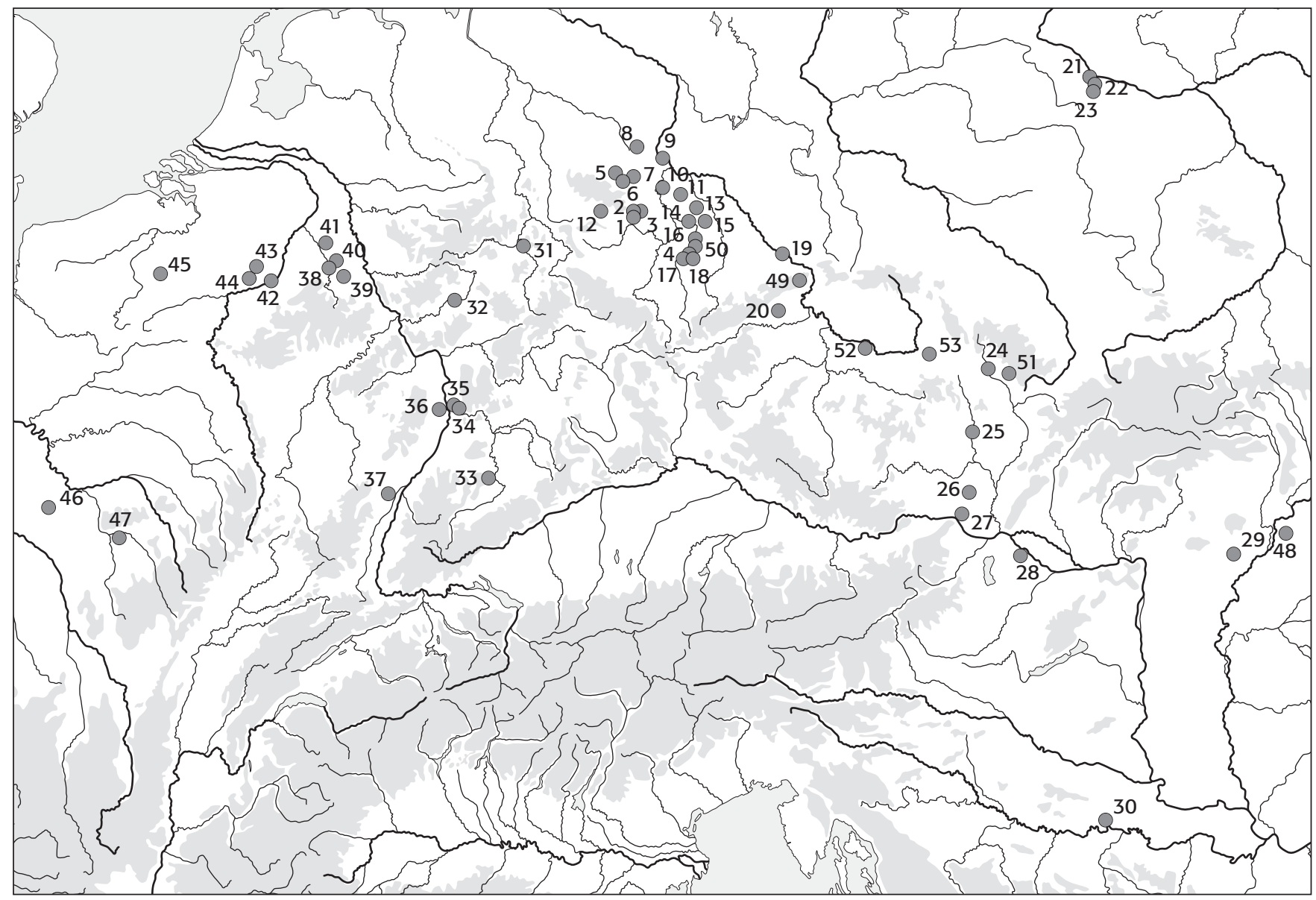

Fig. 2. Locations of Early Neolithic wells in Central Europe. - Obr. 2. Rozmístění časně neolitických studní ve střední Evropě: $\mathbf{1}$ - Niederröblingen; $\mathbf{2}-$ Riestedt; $\mathbf{3}$ - Emseloh; 4 - Rehmsdorf/Rumsdorf; 5 - Halberstadt-Sonntagsfeld; 6 - Quedlinburg; 7 - Gatersleben; 8 - Elbeu; 9 - Schönebeck (Elbe); 10 - Peißen/Bernburg; 11 - Weißandt-Gölzau; 12 - Nordhausen; 13 - Brodau; 14 - Altscherbitz; 15 - Leipzig-Plaußig; 16 - Eythra/Zwenkau; 17 - DroßdorfPeres; 18 -Meuselwitz-Zipsendorf; 19 -Dresden-Cotta; 20 - Most; 21 -Smólsk; 22 - Kruszyn; 23 - Ludwinowo; 24 - Mohelnice; 25 - Brno; 26 Schletz/Asparn (a. d. Zaya); 27 - Würnitz; 28 - Lébény; 29 - Füzesabony-Gubakút; 30 -Zadubravlje; 31 - Hesserode; 32 - Wetzlar-Dalheim; 33 - Gerlingen; $\mathbf{3 4}$ - Mannheim-Wallstadt/Straßenheim; 35 - Mannheim-Vogelstang; 36 - Fußgönheim; 37 - Ittenheim; 38 - Arnoldsweiler; 39 - Müddersheim; 40 Morschenich; 41 - Erkelenz-Kückhoven; 42 - Hollogne-Douze Bonniers; 43 - Oleye-Al Zèpe; 44 - Darion-Colia, Hes baye; 45 - Ormeignies; 46 - Échilleuses; $\mathbf{4 7}$ - Cheny; $\mathbf{4 8}$ - Sajószentpéter; $\mathbf{4 9}$ - Dresden-Nickern; $5 \mathbf{0}$ - Großstolpen; $\mathbf{5 1}$ - Uničov; $\mathbf{5 2}$ - Velim; $5 \mathbf{3}$ - Ostrov (nos. 1-49 according to / č. 1-49 podle Wollenweber 2016).

spread of steppes and the formation of secondary anthropogenic forest-free areas during the Early and Middle Holocene in eastern Central Europe. They have been reconstructed for several off-site pollen sites (Chytrý 2012). The Moravian lowland landscape was covered by a mosaic of open-canopy woodlands and open habitats (Petr et al. 2013; Kuneš et al. 2015; Jamrichová et al. 2017; Dudová et al. 2018). Local environmental gradients, such as the type of bedrock, moisture level or hillslope aspect are key factors shaping the habitat variability of the area, which ranges from alluvial woodlands (Petr - Novák 2014) to steppe patches (Pokorný et al. 2015). Charcoals, plant macroremains and animal bones are used as on-site evidence of a settlement environment. Environmental samples have been systematically recovered, subjected to flotation and analysed for only a few recently excavated LBK sites in eastern Central Europe (e.g. Novák - Krasnokutská 2009; Lenneis 2010; Hajnalová 2011; Vostrovská et al. 2019). Consequently, there is a difference between off-site and on-site data. The off-site palaeoecological proxy record indicates a mixed deciduous for- est. On-site data are very poor in species, landscape reconstructions are almost always identical and, by contrast, the evidence mostly indicates open stands with shrubs (Vostrouská et al. 2019).

An archaeological rescue excavation at the Uničov - U kravína site has exposed an LBK settlement with a wooden well, which is its most unique feature. We used a combination of methods to address topics of archaeology and palaeoecology. The primary aim is (1) to reconstruct the process by which the well was built. Secondly (2), we explore the well's usage and decline in an attempt to study how water was managed by prehistoric farmers. Thirdly (3), we examine the spectrum of plants consumed or otherwise utilized by the first farmers living at the site, for example as for construction purposes or as firewood. Finally, we aim (4) to explore what the local environment looked like and how the first farmers could have influenced their surroundings, to what extent the environment changed throughout the Neolithic and when the prehistoric cultural landscape emerged in the region of Moravia. 


\section{Material and methods}

\subsection{Site description}

The town of Uničov is situated in the northeastern tip of central Moravia, at the foothills of the Nízký Jeseník highland (Culek et al. 2005). Its environmental conditions make this region relatively secluded, which is reflected in its prehistoric development. The bedrock consists of gravel-sand fluvial deposits mostly overlaid by loess, which is covered with fertile soil. The site is situ- ated ca $230 \mathrm{~m}$ from the left bank of the now regulated river bed of the Lukavice stream. This is probably the closest surface water source in the Neolithic period. Another watercourse is the Oskava stream located about $1,100 \mathrm{~m}$ away. It is a tributary of the river Morava and comprises a broad alluvium at elevations of 233-234 m ASL (Fig. 3). The present-day average annual temperature and rainfall are $9^{\circ} \mathrm{C}$ and $550 \mathrm{~mm}$, respectively.

In November and December 2015, the Archaeological Centre Olomouc conducted an archaeological rescue excavation at the construction site of a factory hall and

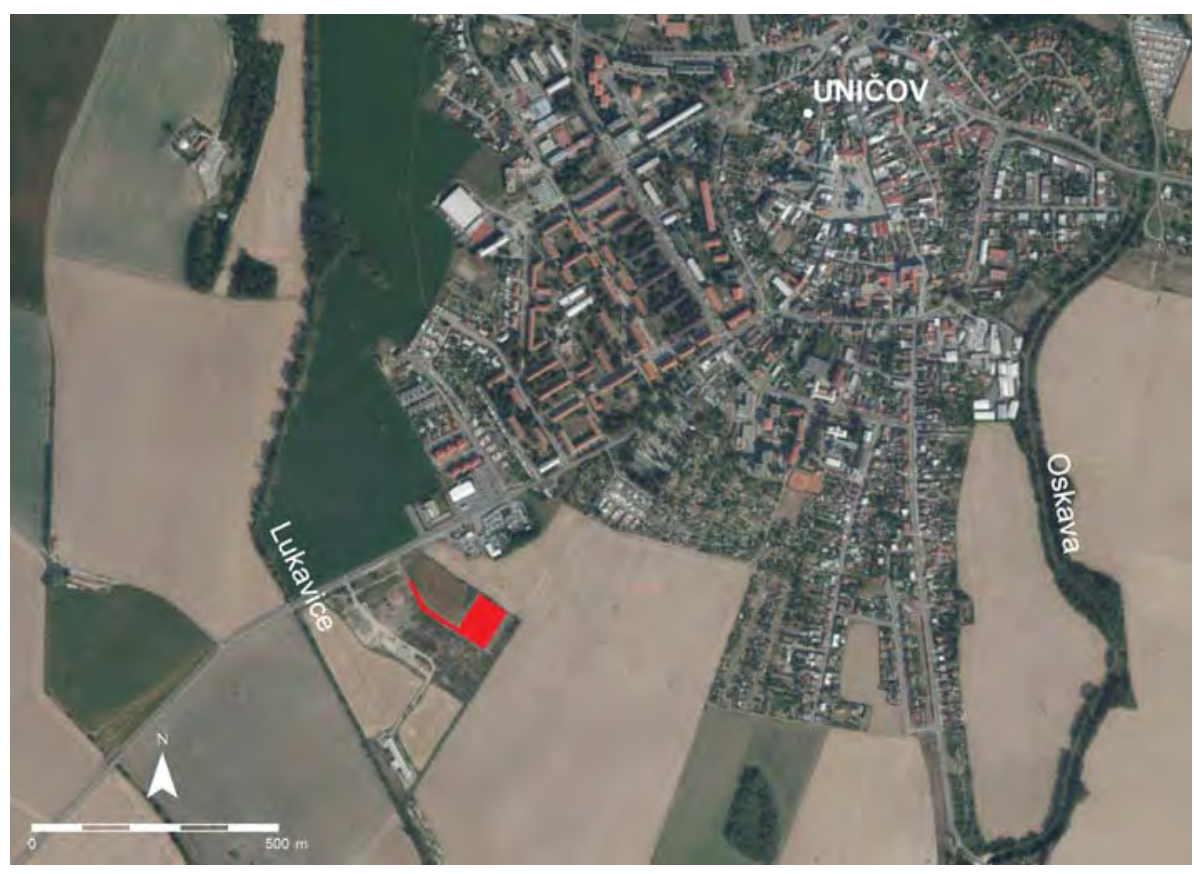

Fig. 3. Site location - marked in red (৫ČÚZK). - Obr. 3. Umístění lokality - vyznačeno červeně (@ČÚZK).

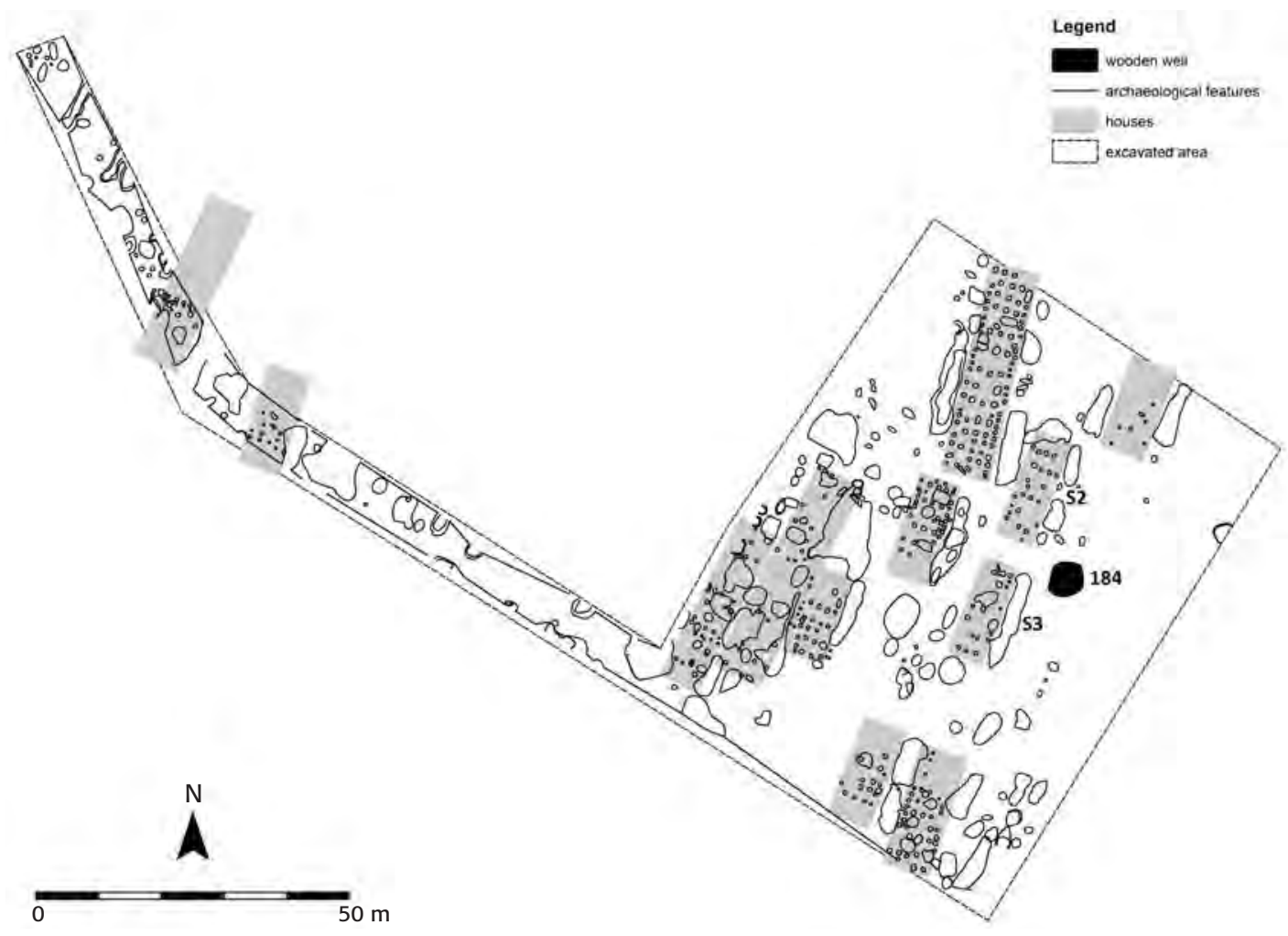

Fig. 4. Linearbandkeramik settlement at the Uničov site (author I. Vostrovská). - Obr. 4. Sidliště kultury s lineární keramikou v Uničově (autorka l. Vostrovská). 
an access road on the southwest border of the town of Uničov at a place called U kravína. On an area of 0.7 ha, 556 features of the LBK and two settlement pits of the Jordanów culture were explored (Kalábek 2016). The excavation unearthed one part of a settlement area of the LBK with 12 'longhouse' layouts with a five-row post-construction, building pits, irregular composite pits, storage pits and ovens. An exceptional find was a water well with a preserved timber lining (feature 184). The well was situated in the immediate neighbourhood of house S2 and house S3 (Fig. 4).

\subsection{Fieldwork}

After the removal of the topsoil layer, the well had the form of an oval pit sized $580 \times 550 \mathrm{~cm}$, oriented in the northeast-southwest direction (Fig. 5). The feature was divided into six sectors which were gradually excavated. The excavation was carried out crosswise in opposite parts in order to make the cross-section through this feature as long as possible (Fig. 6). The uppermost layer of the feature consisted of dark brown silty soil $80 \mathrm{~cm}$ in thickness (context 300). A total of 110 ceramic fragments were found in the infill of the funnel-shaped well pit (Fig. 7: 1-15). However, it soon became evident that the infill of the pit narrowed towards the centre and that its structure and colour varied. About one metre deeper, the moderately inclined funnel-shaped mouth of the pit turned abruptly into a nearly vertical wall falling down to a depth of $325 \mathrm{~cm}$. This funnel was filled with yellowbrown compacted clayey soil (context 302).

In the middle of this infill, at a depth of $120 \mathrm{~cm}$ below the surface, a dark black, clayey, irregular rhombic ground plan was detected, indicating the original timber lining of the well shaft. The length of its sides was 90$100 \mathrm{~cm}$ and the infill consisted of water-saturated brown-black silty clay with many organic remains (context 315). Only two whole ceramic vessels and 11 ceramic vessel fragments were found in the well shaft
(Fig. 7: 16-23). The outer side of the timber lining of the well shaft was daubed with an approximately $6-\mathrm{cm}$ layer of grey clay (context 316; Fig. 8) and a total of nine ceramic fragments were found in it (Fig. 7: 24-26). The upper groundwater level was reached at a depth of $170 \mathrm{~cm}$ below the surface after the removal of topsoil, where the preserved wooden lining began to appear. This construction was gradually dismantled and continued to the depth of $320 \mathrm{~cm}$. The whole infill of the well shaft was removed in 10- and $20-\mathrm{cm}$ layers down to the depth of $325 \mathrm{~cm}$. The sediment from the infill was put into plastic bags for detailed multi-proxy palaeoecological analyses. It was not possible to take out more sediment because the large amount of groundwater in the well could not be pumped off.

At a depth of $260 \mathrm{~cm}$, two parallel cores were sampled from the wet well infill using an open tube $8 \mathrm{~cm}$ in diameter and $100 \mathrm{~cm}$ long (manufactured by Eilkamp) to obtain a precise stratigraphy of the well infill. The first core reached the gravel bedrock at a depth of $345 \mathrm{~cm}$ and thin-section samples $3 \mathrm{~cm}$ thick were sampled for micromorphological, palynological and geochemical analyses. The second core only reached a depth of $310 \mathrm{~cm}$. It was sampled every $5 \mathrm{~cm}$ and the material was put into zip lock bags and stored in a fridge for future use.

\subsection{Dendrochronology and radiocarbon dating}

We took samples from all wooden elements of the well that were suitable for dendrochronological analysis, with an increment borer or chainsaw. In total, 16 samples were measured using the VIAS TimeTable measuring system devised by SCIEM (OSCIEM). Tree-ring width (TRW) series were measured with an accuracy of $0.01 \mathrm{~mm}$ and synchronized using the software PAST4 (CSCIEM). The mean TRW series were dated according to the oak TRW chronology from Saxony (Tegel et al. 2012). The degree of similarity between the TRW series

Fig. 5. Oval well pit with a moderately inclined funnel-shaped mouth abruptly turning into a nearly vertical wall of the well shaft (photo by M. Kalábek). - Obr. 5. Oválná jáma studny s mírně se svažujícím trychtýřovitým ústím, které se náhle mění v téměř svislou stěnu šachty studny (foto M. Kalábek).

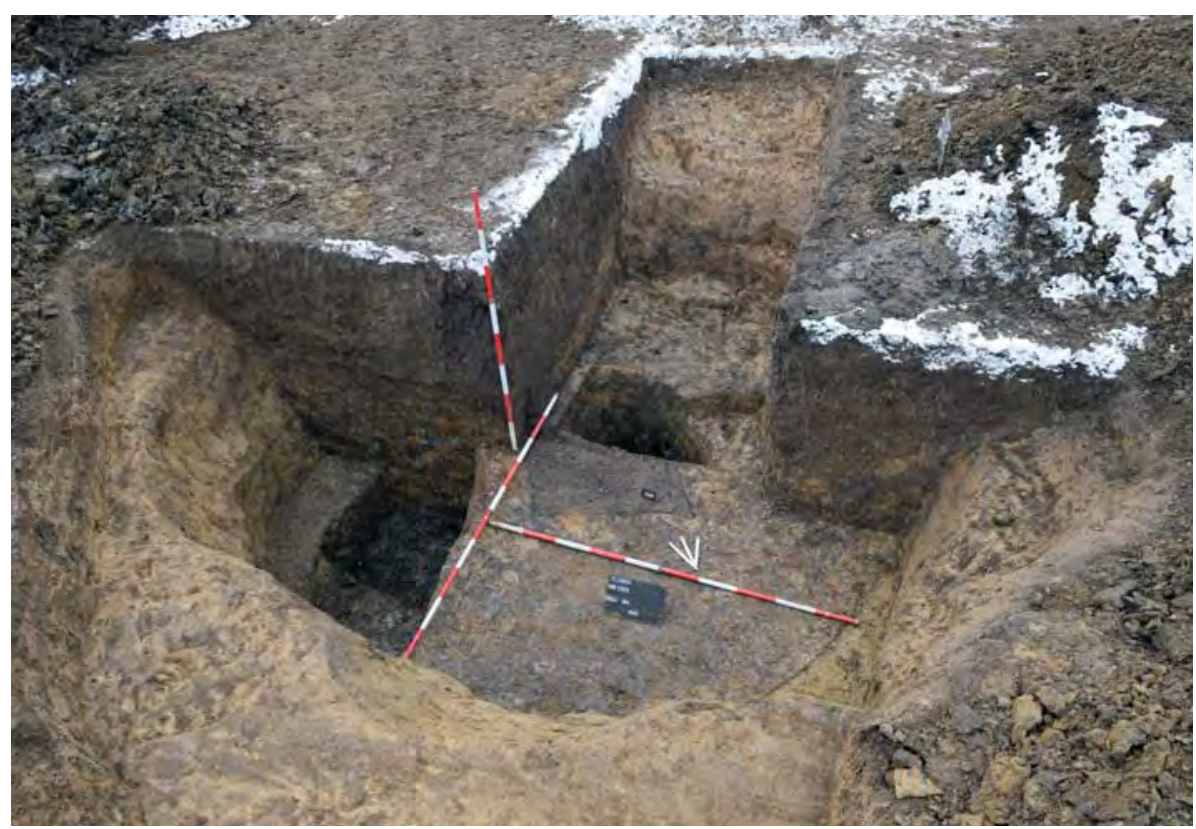




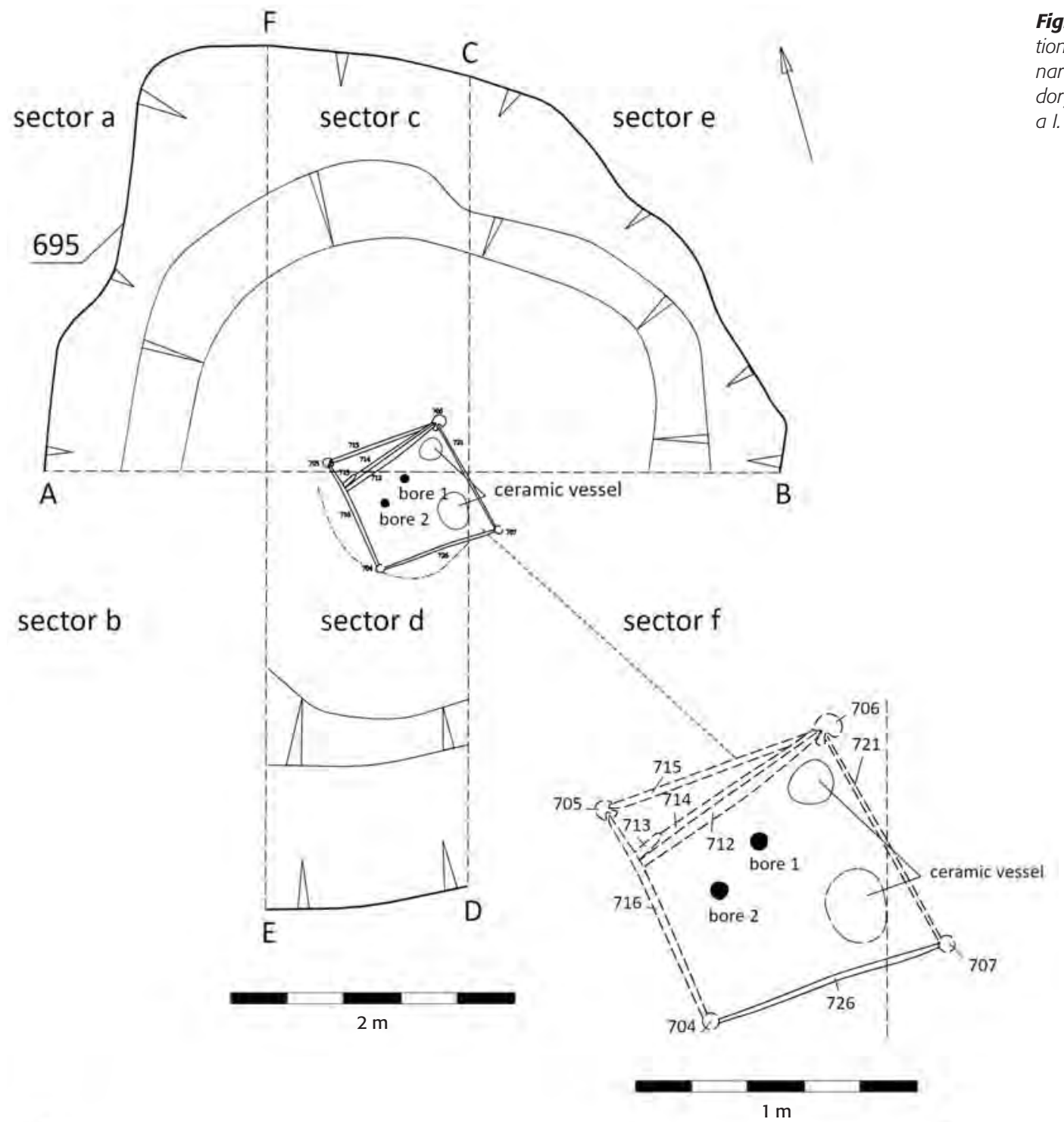

Fig. 6. Ground plan and vertical section of the well infill (authors P. Grenar and I. Vostrovská). - Obr. 6. Püdorys a profil studny (autoři P. Grenar a l. Vostrovská).

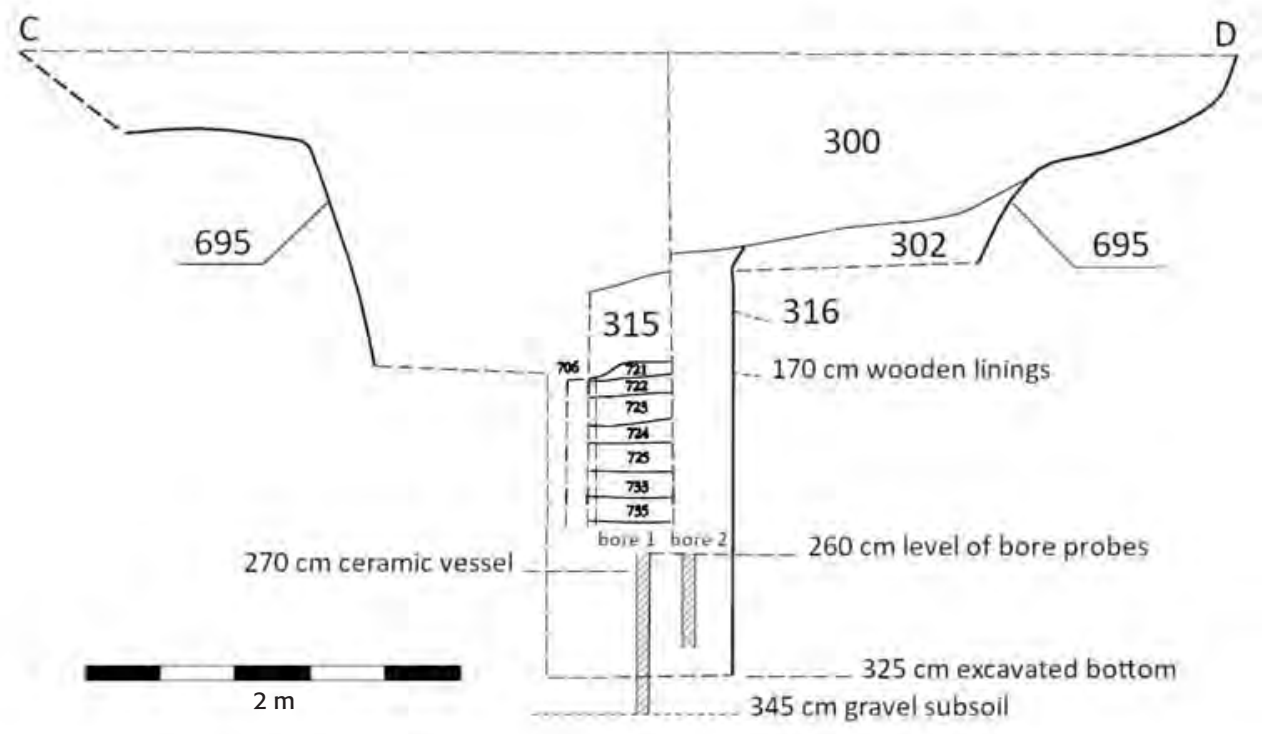

was assessed by t-tests (Gleichläufigkeit: Eckstein Bauch 1969; TBP: Baillie - Pilcher 1973; THO: Hollstein 1980). Woody plants were mainly determined by macroscopic observation. The anatomical determination of woody plants was based on the following literature: Schweingruber $(1990 ; 1990 b)$, Grosser (2007) and Schoch et al. (2004). 


\section{context 300}
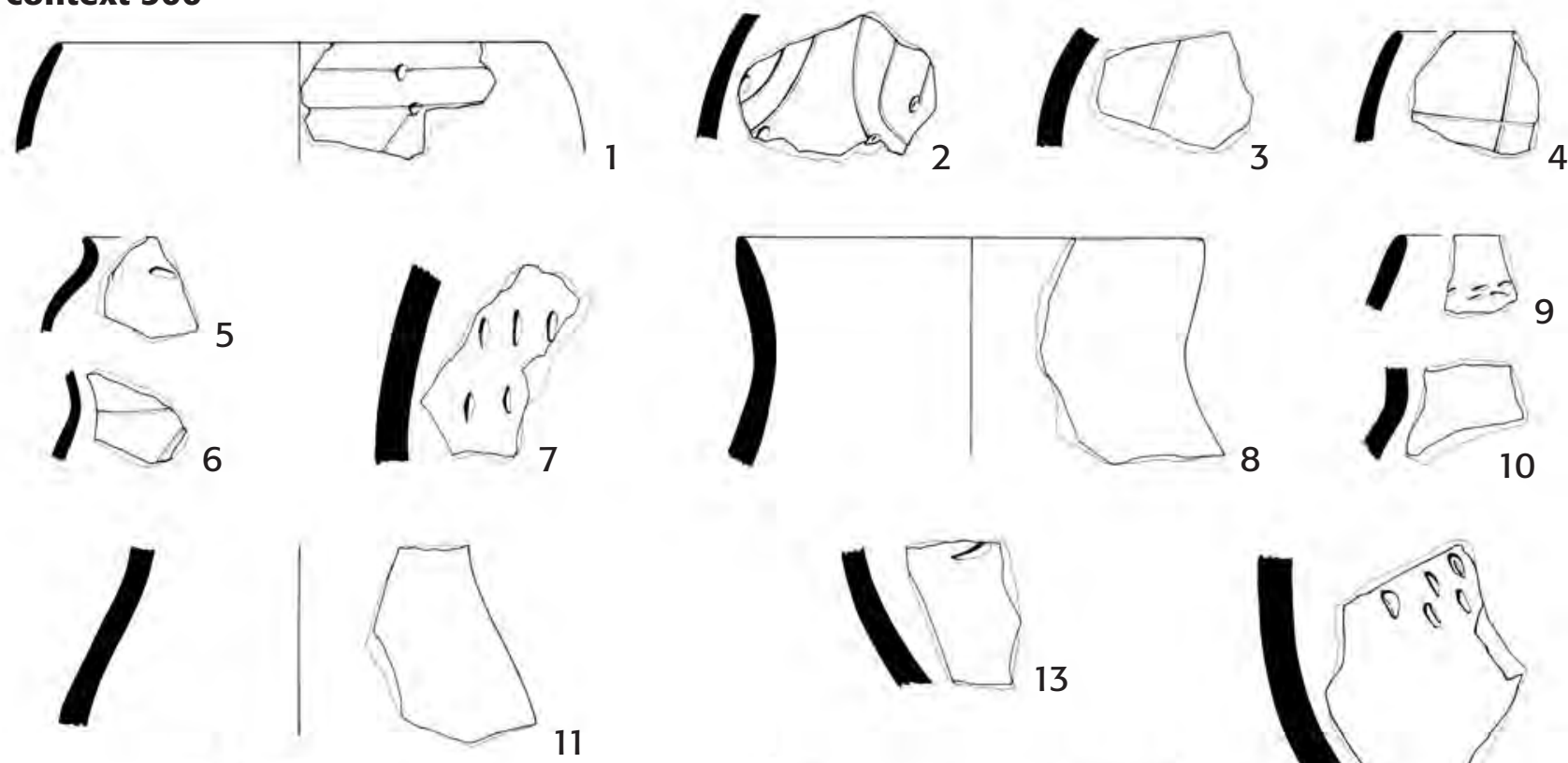

\section{1}
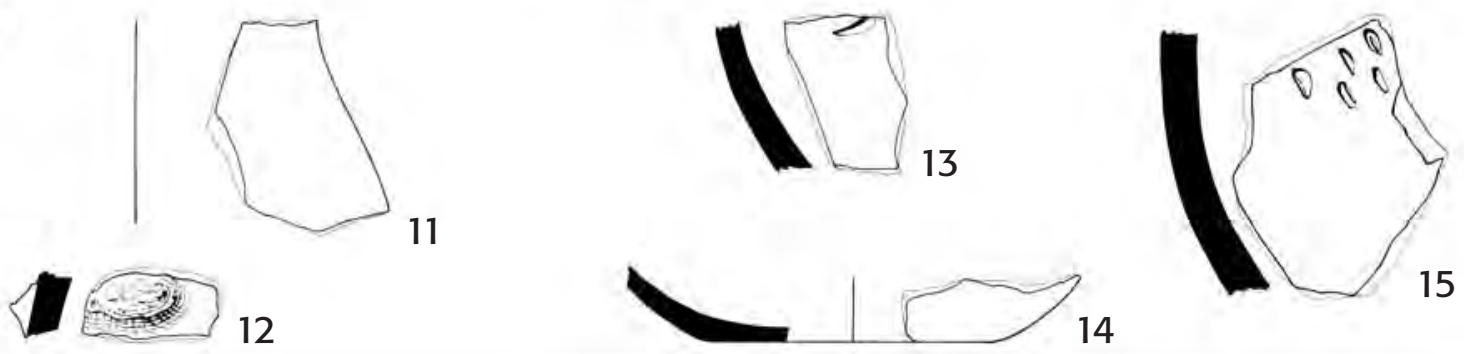

\section{context 315}

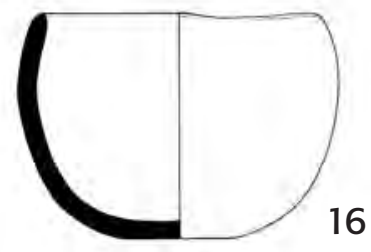

16

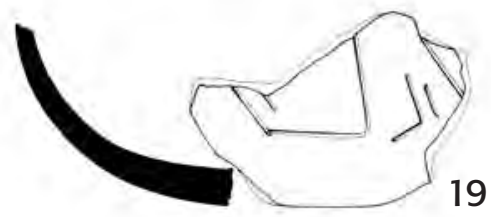

19

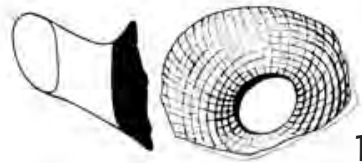

17
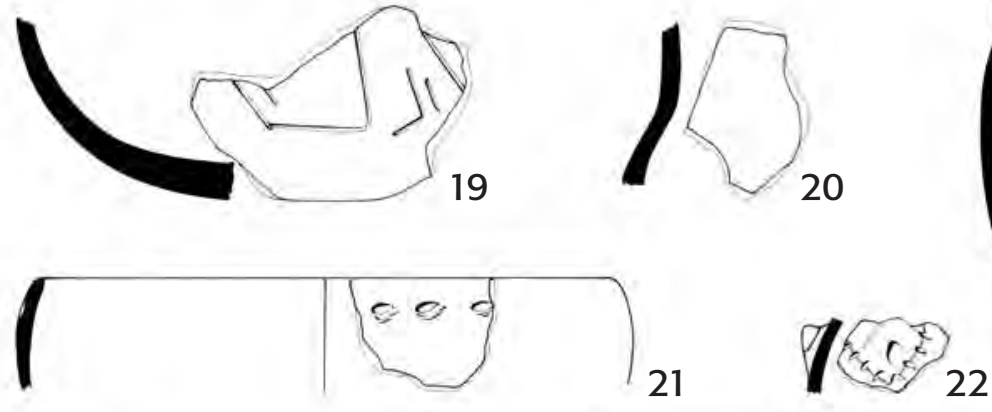

22
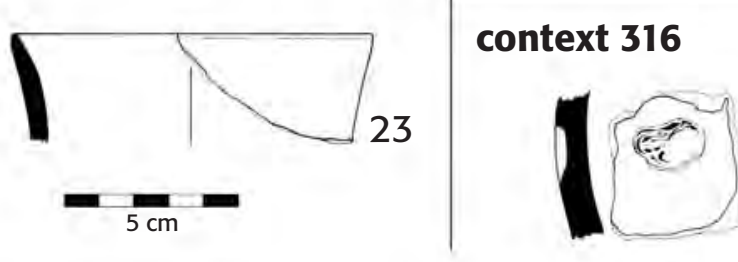

24

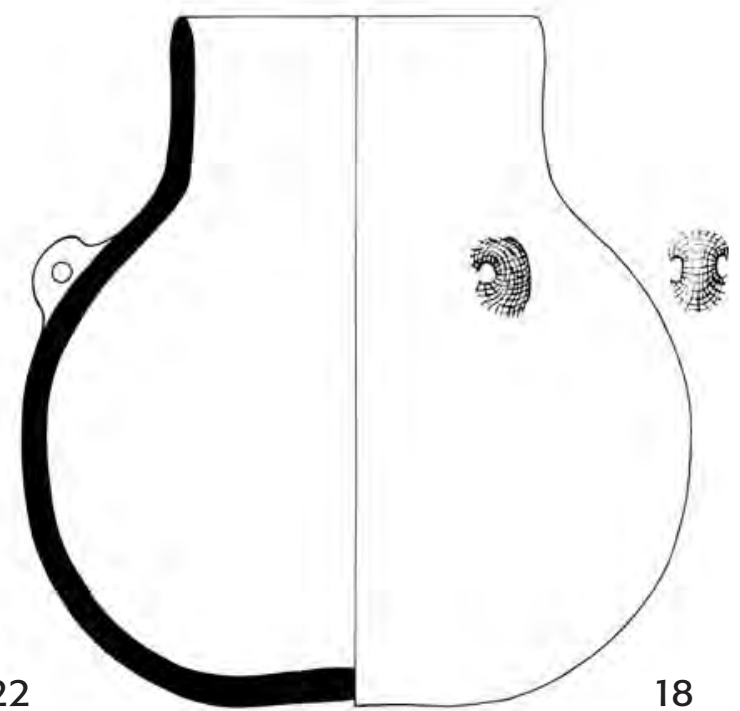

18

Fig. 7. Finds of $L B K$ pottery. - Obr. 7. Nálezy lineární keramiky: finds from the well infill of the funnel-shaped well pit / nálezy z výplně trychtýřovité studniční jámy: 1 - 17/2015-300-1; 2 - 17/2015-300-2; 3 - 17/2015-300-8; 4 - 17/2015-300-9; 5 - 17/2015-300-10; 6 - 17/2015-300-11; 7 - 17/2015-300-12; 8 - 17/2015-300-13; 9 - 17/2015-300-14; 10 - 17/2015-300-15; 11 - 17/2015-300-16; 12 - 17/2015-300-17; 13 - 17/2015-300-20; 14 - 17/2015-300-21; 15 - 17/2015-300-25. Finds from the well shaft / nálezy z šachty studny: 16 - 17/2015-315-1; 17 - 17/2015-315-4; 18 - 17/2015-315-6; 19 - 17/2015-315-9; 20 - 17/2015-315-10; 21 - 17/2015-315-15; 22 - 17/2015-315-17; 23 - 17/2015-315-33. Finds from the daub layer of grey clay / nálezy z vrstvy omazu šedým jilem: 24 - 17/2015-316-4; 25 - 17/2015-316-1; 26 - 17/2015-316-7 (drawing by / kresba A. Pešková, layout by / rozvržení l. Vostrovská). 


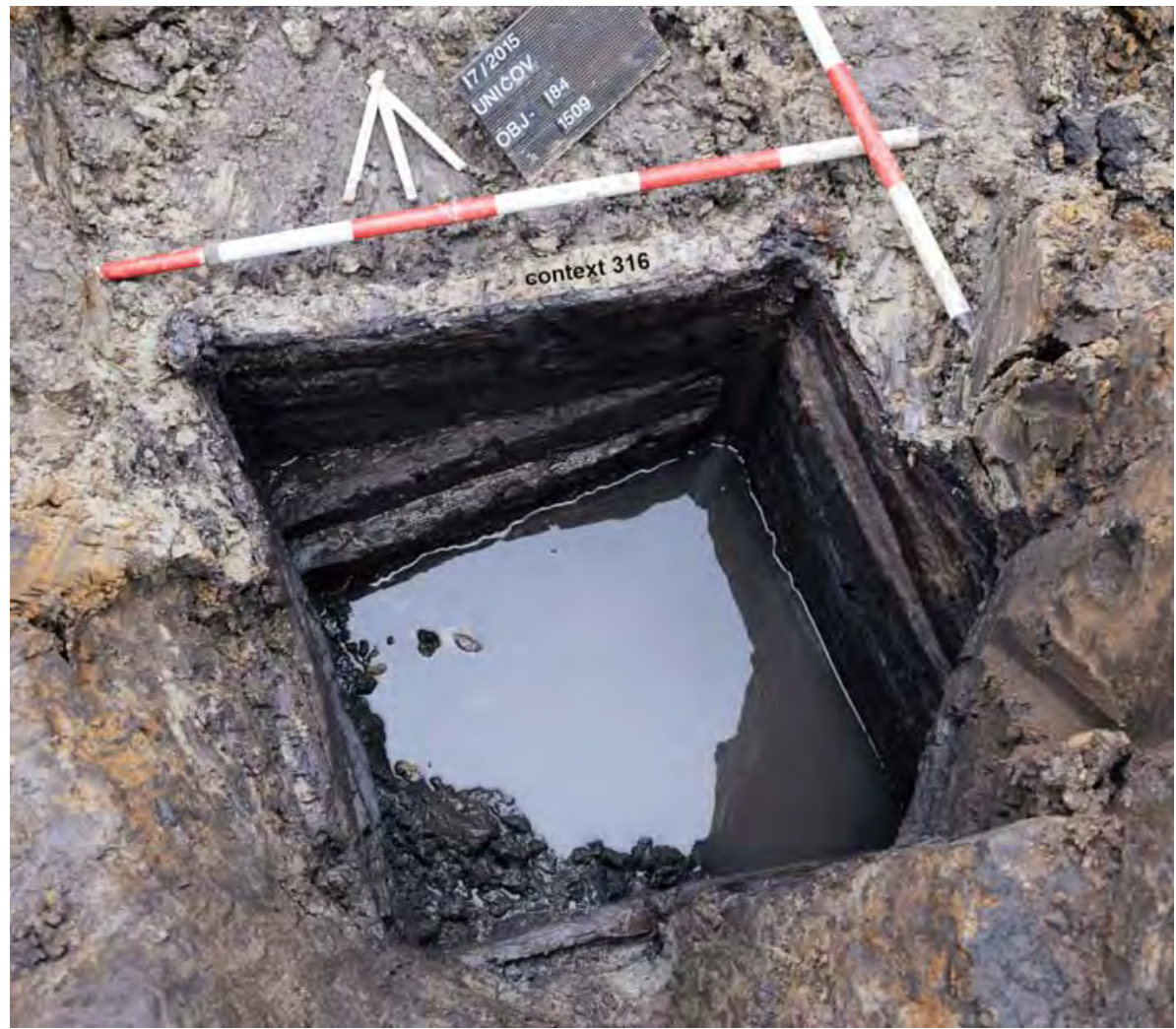

Fig. 8. Layer of grey clay daub (context 316) on the outer side of the wooden construction (photo by M. Kalábek). - obr. 8. Vrstva omazu šedým jilem (kontext 316) na vnějši straně drevěné konstrukce (foto M. Kalábek).

To independently verify the dendrochronological results, a total of 20 samples for radiocarbon dating were taken from the well's lining and infill. These were charred and non-charred plant macroremains, wood and tar coming from the middle and lower part of the infill (from a depth of 180-325 cm). The material was analysed by accelerator mass spectrometry at following laboratories: Isotoptech Zrt. Debrecen, Labor für Ionenstrahlphysik ETH Zürich and at the Curt-EngelhornZentrum Archäometrie Mannheim. The obtained data were calibrated using OxCal version 4.3 (95.4\% $\% 2 \sigma$; $\mu \pm 1 \sigma$ ). To compare the accuracy of the data, in six cases, samples of charred and non-charred macroremains from the same depth (achenes of Onopordum and Chenopodium; grains of Triticum dicoccum and Triticum monococcum) were dated independently at two laboratories.

\subsection{Trace evidence}

The 47 wooden objects from the construction and infill of the well exhibited a variety of tool marks and indirect evidence of woodworking. Scale drawings of the crosssections were produced for all wooden objects to investigate dendrological parameters (pith, sapwood, waney edge, orientation of tree-rings and rays) and to establish their position in the trunk. From this information, minimum stem diameters and indications on the longitudinal splitting processes were obtained. Single tool marks were documented to obtain minimum blade widths. Manufacturing procedures were identified on the basis of techno-morphological features and in consultation of archaeological (e.g. Böhm - Pleyer 1990; Weiner
- Lehmann 1998; Elburg 2008; Tegel et al. 2012) and ethno-archaeological research (e.g. Pétrequin - Pétrequin 1993) as well as experimental studies and experience (Meier 1990; Choulot et al. 1997; Arnold 2003; Lobisser 2005; Elburg et al. 2015). The results of these analyses were evaluated by the laboratory Jahrringlabor der Professur für Waldwachstum und Dendroökologie der Universität Freiburg.

\subsection{Lithostratigraphy}

A basic macroscopic description of the lithostratigraphy was carried out on site and during the sampling of cores in the laboratory. The recognized layers were analysed in detail in thin sections sampled at certain depths from two parallel cores (core 1: samples 1, 9, 10, 11 and 12; core 2: samples 2, 3, 4 and 5) and from blocks of sediment collected during the fieldwork (samples 6, 7 and 8). Thin sections sized $2.5 \times 5 \mathrm{~cm}$ were air-dried, impregnated, cut into slices, installed on a glass slide and polished to a thickness of about $30 \mu \mathrm{m}$. They were then analysed under a polarizing microscope in plane-polarized light (PPL) and under cross-polarized light (XPL), following the standard guidelines (Bullock et al. 1985; Stoops - Eswaran 1986; Stoops 2003). The weight percentage of organic matter was determined by means of loss on ignition (LOI 550), which indicates the proportion of organic matter (Heiri - Lotter - Lemcke 2001). Samples were dried at $105^{\circ} \mathrm{C}$ for 24 hours and combusted for three hours at $550^{\circ} \mathrm{C}$. Magnetic susceptibility was measured using an Agico Kappabridge MFK1FA device set at two frequencies $(976 \mathrm{~Hz}$ and 15,616 Hz) operating with a magnetic field amplitude of $200 \mathrm{~A} / \mathrm{m}$. 
Frequency-dependent magnetic susceptibility was calculated for each sample from the frequencies obtained. Chemical composition was determined using an ED-XRF spectrometer Rigaku NexCG with a 50-W Pd tube using an SSD detector with $145-\mathrm{eV}$ resolution. The duration of each measurement was 120 seconds for every secondary target. Samples were measured in the form of homogenized pressed pellets. Quantification was performed for the following elements: Al, Si, P, S, K, Ca, Ti, $\mathrm{Mn}, \mathrm{Fe}, \mathrm{Ni}, \mathrm{Cu}, \mathrm{Zn}, \mathrm{As}, \mathrm{Rb}, \mathrm{Sr}, \mathrm{Sb}$ and $\mathrm{Pb}$.

\subsection{Palynology}

All 28 samples were processed using the standard acetolysis method (Moore - Webb - Collingson 1991) for pollen analysis. The volume of individual samples was approximately $1 \mathrm{~cm}^{3}$. First of all, each sample was boiled for 10 minutes in $10 \% \mathrm{KOH}$ and was then wetsieved. Afterwards it underwent 24 hours of leaching in HF without boiling. The next procedure was boiling for 5 minutes in an acetolysis mixture of sulfuric acid $\left(\mathrm{H}_{2} \mathrm{SO}_{4}\right)$ and acetic anhydride $\left[\left(\mathrm{CH}_{3} \mathrm{CO}\right)_{2} \mathrm{O}\right]$ at a ratio of $1: 9$. The sample was then transferred to a mixture of water and glycerol. Pollen samples were coloured with safranin to emphasize pollen grain against the rest of the organic matter. Each sample was examined under a standard optical microscope at 400x magnification. A pollen atlas was used for pollen grain identification (Beug 2004). Pollen diagrams were plotted in POLPAL (Walanus - Nalepka 1999). The pollen sum in each sample was at least 200 grains, excluding aquatic types and non-pollen objects.

\subsection{Anthracology, xylotomy, plant macroremains, mosses, zoology and entomology}

The methodology of the sampling was implemented so as to enable multi-proxy research. Different sampling strategies were used throughout the excavation. A total of 57 samples of sediment were recovered from well's infill. The whole infill of the well shaft was sampled for further analysis. Because of the lack of apparent stratification of the vertical section, bulk samples of the sediment were taken from layers 10 or $20 \mathrm{~cm}$ in thickness (1-3 samples per layer). All samples were wet-sieved on a $2-\mathrm{mm}$ sieve and the coarse fraction was sorted into charcoals, wood fragments and large seeds. Only 20 samples of 21 volume were also processed using a $0.25-\mathrm{mm}$ sieve because of the high concentration of environmental material. Smaller seeds, fruits and other plant macroremains were sorted directly from wet-sieved samples. The remaining heavy residue was sorted immediately after flotation (Pearsall 2001). In total, 5721 of sediment were processed. The environmental material was sorted and identified under a stereomicroscope.

In total, 57 samples containing charcoals and wood fragments were analysed. Transverse, radial and tangential sections were made on each fragment, and fresh fracture surfaces were directly examined using an episcope interference microscope with 50x, 100x and 200x magnification. The total weight of charcoal in each sample was weighed with the accuracy of $0.001 \mathrm{~g}$, and an- thracomass in mg of charcoal per kg of sediment was determined based on charcoals larger than $1 \mathrm{~mm}$ (TalonCarcaillet-Thin 1998). Wood species identification, including charcoals, was performed according to Schweingruber (1990a; 1990b).

The macroremains assemblage was represented by 20 samples. The residuum of the $>2 \mathrm{~mm}$ fraction was scanned for wood fragments. Seeds, fruits and other plant macroremains were sorted out from wet samples. Their determination was performed using a reference collection, atlases and keys to seeds (Anderberg 1994; Berggren 1981; Beijerinck 1947; Cappers - Bekker Jans 2006; Jacomet 2006).

Photographs of mosses were made using an Olympus BX60 microscope equipped with an Olympus DP 72 camera, using QuickPHOTO CAMERA 3.0 software. The nomenclature of mosses follows the last edition of the Checklist and Red List of Bryophytes of the Czech Republic (Kučera - Váňa - Hradílek 2012).

The assemblage of the microfauna was analysed by standard methods of archaeozoology, see for example Reitz - Wing 2008. Bone determination was carried out using both an osteological collection and osteological atlases (Schmid 1972; Anděra - Horáček 1982; Červený Komárek - Štěrba 1999). Because of the tiny weight of remains, in the case of the assemblage obtained by flotation, only the number of finds and minimum number of individuals were recorded; for the quantification methods in archaeozoology, see Kysely 2004.

Insect remains were identified according to comparative collections and modern keys for particular groups. Individuals in the assemblage were quantified as the number of identified specimens (NISP) and the minimum number of individuals (MNI; Lyman 2008).

\section{Results and interpretation}

\subsection{Dendrochronology and radiocarbon dating}

The well-preserved wooden construction provided nine absolutely dated TRW series of oak (Quercus spp.). The samples originate from the well's lining as well as from the infill. Most of the dated oak wood samples still contained sapwood, so the analysed samples could be dated more precisely. The number of sapwood tree rings detected in the dated Quercus samples falls within the range (5-25 rings) defined by Prokop et al. (2017). The trees used for the well construction were cut between 5093 and 5085 BC (Rybníček et al. 2018, 100-101).

After calibration of the radiocarbon data, the timber lining and well filling fell within a rather wide interval of 5464-4615 cal. BC (Tab. 1), a result compatible with the dendrochronological dating. The data for achenes, seeds and cereals from the filling (5302-4979 cal. BC) and wood from the lining (5290-5026 cal. BC) are comparable (Fig. 9). A total of three samples stand out from the whole series of radiocarbon data. A hornbeam seed (Carpinus betulus) was dated to the interval of 54645220 cal. BC, which is the oldest of all the samples. Two samples were obtained from moss residues (Drepanocladus aduncus). The value for the first sample, 48364615 cal. BC, deviates from the series as the youngest 


\begin{tabular}{|c|c|c|c|c|c|c|c|}
\hline Sample & $\begin{array}{c}\text { Stratigraphic } \\
\text { unit }\end{array}$ & $\begin{array}{c}\text { Absolut } \\
\text { depth (cm) }\end{array}$ & Material & Lab Code & ${ }^{14} \mathrm{C}$ age & $\begin{array}{l}\text { Oxcal cal } 95.4 \% \\
\text { interval }( \pm 2 \sigma)\end{array}$ & $\begin{array}{l}\text { Oxcal cal } \mu \\
\left(\begin{array}{l} \pm 1 \\
1\end{array}\right)\end{array}$ \\
\hline Uničov, f. 184 & 315 & $120-130$ & charred Cerealia, Sambucus, Canium & DeA-21499 & $6005 \pm 39 \mathrm{BP}$ & $4996-4796$ BC & $4896 \pm 55 \mathrm{BC}$ \\
\hline Uničov, f. 184 & 315 & $180-190$ & uncharred Cerealia & DeA-13934 & $6208 \pm 30 \mathrm{BP}$ & $5292-5056$ BC & $5154 \pm 64 \mathrm{BC}$ \\
\hline Unicov, f. 184 & 315 & $180-190$ & uncharred Onopordum acanthium & ETH84332.1.1 & $6130 \pm 25 \mathrm{BP}$ & $5209-4993$ BC & $5088 \pm 71 \mathrm{BC}$ \\
\hline Uničov, f. 184, 17/2015-316-4 & 316 & $200-210$ & tar from pottery & DeA-17682 & $6151 \pm 40 \mathrm{BP}$ & $5221-4981$ BC & $5109 \pm 69 \mathrm{BC}$ \\
\hline Uničov, f. 184 & 315 & $220-230$ & uncharred Onopordum & DeA-13933 & $6129 \pm 30 \mathrm{BP}$ & 5211-4979 BC & $5087 \pm 72 B C$ \\
\hline Uničov, f. 184 & 315 & $220-230$ & uncharred Carpinus betulus & DeA-17378 & $6338 \pm 34 \mathrm{BP}$ & $5464-5220 \mathrm{BC}$ & $5319 \pm 52 \mathrm{BC}$ \\
\hline Uničov, f. 184 & 315 & $220-230$ & charred Cerealia & ETH84333.1.1 & $6185 \pm 25 \mathrm{BP}$ & $5221-5047 \mathrm{BC}$ & $5133 \pm 50 \mathrm{BC}$ \\
\hline Uničov, f. 184 & 315 & $230-240$ & uncharred Onopordum & DeA-13932 & $6138 \pm 30 \mathrm{BP}$ & $5211-4996$ BC & $5100 \pm 69 \mathrm{BC}$ \\
\hline Uničov, f. 184 & 315 & $230-240$ & charred Triticum dicoccum & ETH84334.1.1 & $6220 \pm 30 \mathrm{BP}$ & 5300-5061 BC & $5176 \pm 71 \mathrm{BC}$ \\
\hline Uničov, f. 184 & 315 & $230-240$ & charred Triticum monococcum & ETH84335.1.1 & $6195 \pm 30 \mathrm{BP}$ & $5289-5042 \mathrm{BC}$ & $5140 \pm 57 \mathrm{BC}$ \\
\hline Uničov, f. 184, 714 B 1 & 714 & $260-275$ & wood & MAMS-26872 & $6166 \pm 30 \mathrm{BP}$ & $5215-5027 \mathrm{BC}$ & $5124 \pm 54 \mathrm{BC}$ \\
\hline Uničov, f. 184, 714 B 2 & 714 & $260-275$ & wood & MAMS-26873 & $6165 \pm 29 \mathrm{BP}$ & $5215-5030 \mathrm{BC}$ & $5124 \pm 54 \mathrm{BC}$ \\
\hline Uničov, f. 184, 734-1 & 734 & $260-275$ & wood & MAMS-26874 & $6205 \pm 30 \mathrm{BP}$ & $5290-5055$ BC & $5150 \pm 60 \mathrm{BC}$ \\
\hline Uničov, f. 184, 734-2 & 734 & $260-275$ & wood & MAMS-26875 & $6168 \pm 31 \mathrm{BP}$ & $5216-5026 \mathrm{BC}$ & $5125 \pm 54 \mathrm{BC}$ \\
\hline Uničov, f. 184 & 315 & $280-300$ & uncharred Onopordum & DeA-13930 & $6168 \pm 31 \mathrm{BP}$ & $5218-5022 \mathrm{BC}$ & $5125 \pm 57 \mathrm{BC}$ \\
\hline Uničov, f. 184 & 315 & $280-300$ & uncharred Drepanocladus aduncus & DeA-15368 & $5865 \pm 41 \mathrm{BP}$ & 4836-4615 BC & $4735 \pm 51 \mathrm{BC}$ \\
\hline Uničov, f. 184 & 315 & $300-325$ & uncharred Chenopodium & DeA-13931 & $6145 \pm 29 \mathrm{BP}$ & $5211-5001 \mathrm{BC}$ & $5109 \pm 66 \mathrm{BC}$ \\
\hline Uničov, f. 184 & 315 & $300-325$ & uncharred Drepanocladus aduncus & DeA-15401 & $6101 \pm 40 \mathrm{BP}$ & $5209-4910 \mathrm{BC}$ & $5039 \pm 81 \mathrm{BC}$ \\
\hline Uničov, f. 184 & 315 & $300-325$ & charred Triticum monococcum & ETH84336.1.1 & $6230 \pm 25 \mathrm{BP}$ & $5302-5071$ BC & $5205 \pm 68 \mathrm{BC}$ \\
\hline Uničov, f. 184 & 315 & $300-325$ & charred Triticum dicoccum & ETH84337.1.1 & $6200 \pm 25 \mathrm{BP}$ & $5286-5051 \mathrm{BC}$ & $5141 \pm 55 \mathrm{BC}$ \\
\hline
\end{tabular}

Tab. 1. Radiocarbon results. - Tab. 1. Výsledky radiokarbonového datování.

date and the second sample (5209-4910 cal. BC) is at the lower end of the series of analysed samples. If we look at the overall dating of the well's vertical section, excluding the unclear cases of the oldest hornbeam and the youngest moss, there is no outsize difference in the results. Most of the data are almost the same, which could indicate a rapid filling of the well with settlement waste after its primary function ended. The phases of the functioning and decline of the well cannot be distinguished by radiocarbon dating.

\subsection{Trace evidence}

All of the 47 examined wooden objects were classified as oak (Quercus sp.). Individual species, which can be taken into consideration for Central Europe, namely pedunculate oak (Quercus robur), sessile oak (Quercus petraea) and downy oak (Quercus pubescens), and their hybrids, cannot be distinguished anatomically (Schoch et al. 2004; Dobrovolný et al. 2016).

The preservation state of wood from the well's lining is generally good. Several pieces exhibit typical signs of decay of various intensity. Most of the timbers are still mechanically stable and relatively well preserved. This enabled the constructional classification of building elements and analysis of technical details. The oak well lining rested in four corner posts. Each of these posts was equipped with two longitudinal grooves perpendicular to each other. Rectangular boards were embedded in these grooves and formed the shaft wall. The edges of individual boards were chamfered, so that they fit well into the grooves of the corner posts. The construction of the well had a total of four preserved walls, in which 7-9 pieces of board were set. The preserved well lining had a height of 86-126 cm (Fig. 10). Along the board walls, irregularly placed posts were detected in the inner space of the shaft. Three boards of the lining were found leaning on one of them, as their right end was dislocated from the groove of the corner post.

The majority of the wood pieces examined (Tab. 2) represent radially split wood. Round wood was used in twelve cases, particularly with vertical posts (Fig. 1113: nos. 700-707), but also with three wood pieces from the well infill. In two cases, the boards were split off the tree trunk tangentially (Fig. 16-17: nos. 723 and 725). Several oak timbers contain a fairly large number of tree rings (100-200). Based on very high TBP values and a visual comparison of the tree-ring width series, we can assume that seven of these construction elements came from only two different trunks (Rybníček et al. 2018, 101).

Despite considerable surface erosion, the wooden objects still exhibit well visible and well documentable tool marks. The observation and identification of woodworking and use-wear marks on sub-fossil wooden material allows to draw conclusions with regard to the technological development and processual and ergological knowledge of forestry and raw material use. On the corner posts, pairs of grooves were observed. The width of the grooves varied between 3.5 and $7 \mathrm{~cm}$, and the depth was 4 to $6 \mathrm{~cm}$. In one case (Fig. 12: no. 704) it was possible to measure the height of the middle part dividing the two grooves $(2.5 \mathrm{~cm})$. On the same piece of wood, a worked tip was observed. The point was produced with the help of cutting tools and shows seven facets with a maximum width of $4.3 \mathrm{~cm}$. The thickness of radially split boards or planks varies between 3 and $8 \mathrm{~cm}$, and the thickness of tangential planks (Fig. 16-17: nos. 723 and 725) is approximately 8 or $9 \mathrm{~cm}$. Towards both ends, the grain sides the split wood boards of the well's lining have bilaterally chamfered edges reducing the thickness of the boards to $1-2.5 \mathrm{~cm}$ (e.g. Fig. 16: no. 723). 
Fig. 9. Summary of calibrated dates from timbers of the well's construction and its infill (Reimer et al. 2013; Bronk Ramsey 2017). - Obr. 9. Sumarizace kalibrovaných dat z drev z konstrukce studny a její výplně (Reimer et al. 2013, Bronk Ramsey 2017).

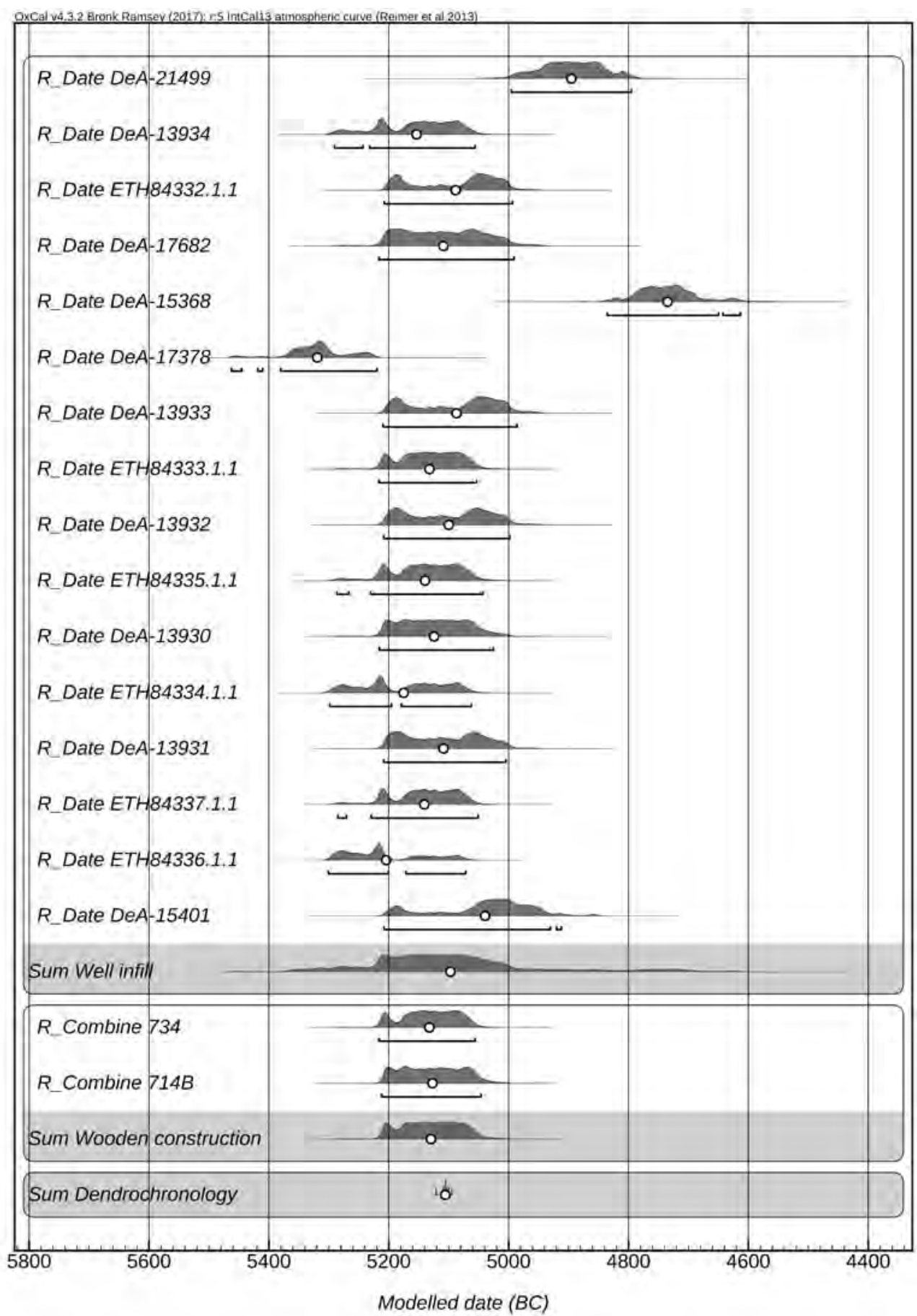

The length of the chamfer varies between 2 and $11 \mathrm{~cm}$. In one case a small offset was observed after $5.5 \mathrm{~cm}$ (Fig. 17: no. 724). The split faces of the boards were modified on their whole surface by flat tangential transverse cuts (e.g. Fig. 15: no. 719 and Fig. 18: no. 732). The narrow sides also are thoroughly treated and edged, but individual tool marks are not preserved.

Although the general preservation state of the wood is good, the possibility to interpret individual blows is limited because of degradation of the wood surface. The width of individual tool marks could be measured in only a few cases. It varies between 2.2 and $3.6 \mathrm{~cm}$ for the split faces of the boards. The cut marks emerged during the tangential surface treatment of the split faces, most probably with the help of an adze. Wider marks were only observed on tangentially split wood no. 723 (Fig. 16), on the sapwood split face (maximum width $7.5 \mathrm{~cm})$. However, in this case it is a trace of rough processing rather than of dressing its edge. The measured widths of individual traces do not necessarily correspond to the width of the cutting edges of individual tools. Nevertheless, they indicate their minimum width. In one case, a split-off along the whole length of the board was observed (Fig. 14: no. 718). Traces of browsing by insects were identified on two pieces of wood. The wood-worm holes were approximately $0.2 \mathrm{~cm}$ wide and they were observed mainly near the sapwood (Fig. 15-16: nos. 720 and 723). 


\begin{tabular}{|c|c|c|c|c|c|c|c|}
\hline Wood no. & Object & Taxon & Sawn timber & $\begin{array}{c}\text { Number } \\
\text { of tree rings } \\
\text { (approx.) }\end{array}$ & $\begin{array}{l}\text { Length } \\
\text { (cm) }\end{array}$ & $\begin{array}{l}\text { Width } \\
\text { (cm) }\end{array}$ & $\begin{array}{l}\text { Strength } \\
\text { (cm) }\end{array}$ \\
\hline 700 & Post & Quercus sp. & Logs & 25 & 76 & 9 & 9 \\
\hline 701 & Post & Quercus sp. & Logs & 20 & 60 & 8.5 & 8.5 \\
\hline 702 & Post & Quercus sp. & Logs & 20 & 116 & 10 & 10 \\
\hline 703 & Post & Quercus sp. & Logs & 26 & 73 & 8 & 8 \\
\hline 704 & Post & Quercus sp. & Logs & 23 & 114 & 13 & 13 \\
\hline 705 & Post & Quercus sp. & Logs & 20 & 80.5 & 12 & 12 \\
\hline $705 / 2$ & Post & Quercus sp. & Logs & 20 & 47 & 18 & 18 \\
\hline 706 & Post & Quercus sp. & Logs & 30 & 76 & 17 & 17 \\
\hline 707 & Post & Quercus sp. & Logs & 25 & 81 & 12.5 & 12.5 \\
\hline 708 & Plank & Quercus sp. & Radially splitting wood & 70 & 69 & 9.5 & 4 \\
\hline 709 & Plank & Quercus sp. & Radially splitting wood & 65 & 82 & 11.5 & 4 \\
\hline 710 & Board & Quercus sp. & Radially splitting wood & 70 & 80.5 & 14.5 & 4.8 \\
\hline 711 & Board & Quercus sp. & Radially splitting wood & 35 & 81 & 12 & 5 \\
\hline 712 & Board & Quercus sp. & Radially splitting wood & 90 & 78 & 16 & 5 \\
\hline 713 & Plank & Quercus sp. & Radially splitting wood & 20 & 14 & 4 & 3 \\
\hline 714 & Board & Quercus sp. & Radially splitting wood & 156 & 83 & 20 & 6.5 \\
\hline 715 & Board & Quercus sp. & Radially splitting wood & 80 & 82 & 11.5 & 5 \\
\hline 716 & Plank & Quercus sp. & Radially splitting wood & 65 & 112 & 10.5 & 3 \\
\hline 717 & Plank & Quercus sp. & Radially splitting wood & 56 & 82 & 15.5 & 4 \\
\hline 718 & Board & Quercus sp. & Radially splitting wood & 70 & 85.5 & 14 & 6.5 \\
\hline $719 / 1$ & Board & Quercus sp. & Radially splitting wood & 120 & 83 & 18 & 5.5 \\
\hline 720 & Board & Quercus sp. & Radially splitting wood & 52 & 84 & 15 & 4.5 \\
\hline 721 & Splinter & Quercus sp. & Radially splitting wood & $<20$ & 15 & 6 & 1 \\
\hline 722 & Plank & Quercus sp. & Radially splitting wood & 40 & 81 & 10.5 & 2 \\
\hline 723 & Board & Quercus sp. & Tangentially splitting wood & 30 & 85.5 & 25 & 9 \\
\hline 724 & Board & Quercus sp. & Radially splitting wood & 66 & 81.5 & 16 & 6 \\
\hline $725 / 1$ & Board & Quercus sp. & Tangentially splitting wood & 40 & 79 & 20 & 8 \\
\hline 726 & Plank & Quercus sp. & Radially splitting wood & 60 & 46.5 & 10 & 3.5 \\
\hline 727 & Plank & Quercus sp. & Radially splitting wood & 40 & 50 & 9 & 4 \\
\hline 728 & Plank & Quercus sp. & Radially splitting wood & 70 & 83.5 & 11 & 3 \\
\hline 729 & Board & Quercus sp. & Radially splitting wood & 70 & 83 & 16 & 6 \\
\hline 730 & Plank & Quercus sp. & Radially splitting wood & 50 & 83 & 14.5 & 4 \\
\hline 731 & Board & Quercus sp. & Radially splitting wood & 58 & 82 & 12.5 & 7 \\
\hline 732 & Board & Quercus sp. & Radially splitting wood & 94 & 68 & 15 & 4.5 \\
\hline 733 & Board & Quercus sp. & Radially splitting wood & 100 & 80 & 19 & 8 \\
\hline 733A & Board & Quercus sp. & Radially splitting wood & 65 & 48 & 12.5 & 5.5 \\
\hline 734 & Board & Quercus sp. & Radially splitting wood & 113 & 78 & 15 & 4.5 \\
\hline 735 & Board & Quercus sp. & Radially splitting wood & 60 & 64 & 13 & 5.5 \\
\hline 736 & Board & Quercus sp. & Radially splitting wood & 71 & 83 & 14.5 & 5 \\
\hline 737 & Plank & Quercus sp. & Radially splitting wood & 61 & 18.5 & 45 & 4 \\
\hline 1509A & Fragment & Quercus sp. & Logs & 18 & 19 & 7.5 & 7.5 \\
\hline 1509B & Fragment (Plank) & Quercus sp. & Radially splitting wood & 55 & 14 & 13.5 & 2 \\
\hline Hloubka 140cm_1 & Fragment (Plank) & Quercus sp. & Radially splitting wood & 65 & 25 & 10 & 4 \\
\hline Hloubka 140cm_2 & Fragment & Quercus sp. & Logs & 5 & 12 & 4.5 & 2.5 \\
\hline Hloubka 140cm_3 & Fragment & Quercus sp. & Logs & 15 & 10.5 & 9 & 6.5 \\
\hline Hloubka 140cm_4 & Fragment (Plank) & Quercus sp. & Radially splitting wood & 65 & 15 & 9 & 3 \\
\hline Hloubka 140cm_5 & Fragment (Plank) & Quercus sp. & Radially splitting wood & 65 & 11 & 9 & 2.5 \\
\hline
\end{tabular}

Tab. 2. List of analysed timber pieces from the well's construction. - Tab. 2. Seznam analyzovaných kusů dreva z konstrukce studny.

\subsection{Lithostratigraphy}

The infill of the Neolithic well was composed of several layers, which greatly differed genetically. These layers were macroscopically divided into five lithostratigraphical units (for a description of the units, see Fig. 19). The individual units were classified into nine sedimentary facies on the basis of a microscopic study of thin sec- tions (Fig. 20). Selected details of individual facies are depicted in Tab. 3.

Facies 1 (343-336 cm, sample 1 - bottom part) was limited to sandy material at the bottom of the well. The layer arose very quickly during the construction of the well, its clearing or during its repair. It was formed by redeposited fluvial sands surrounding the bottom part of the well's construction. 

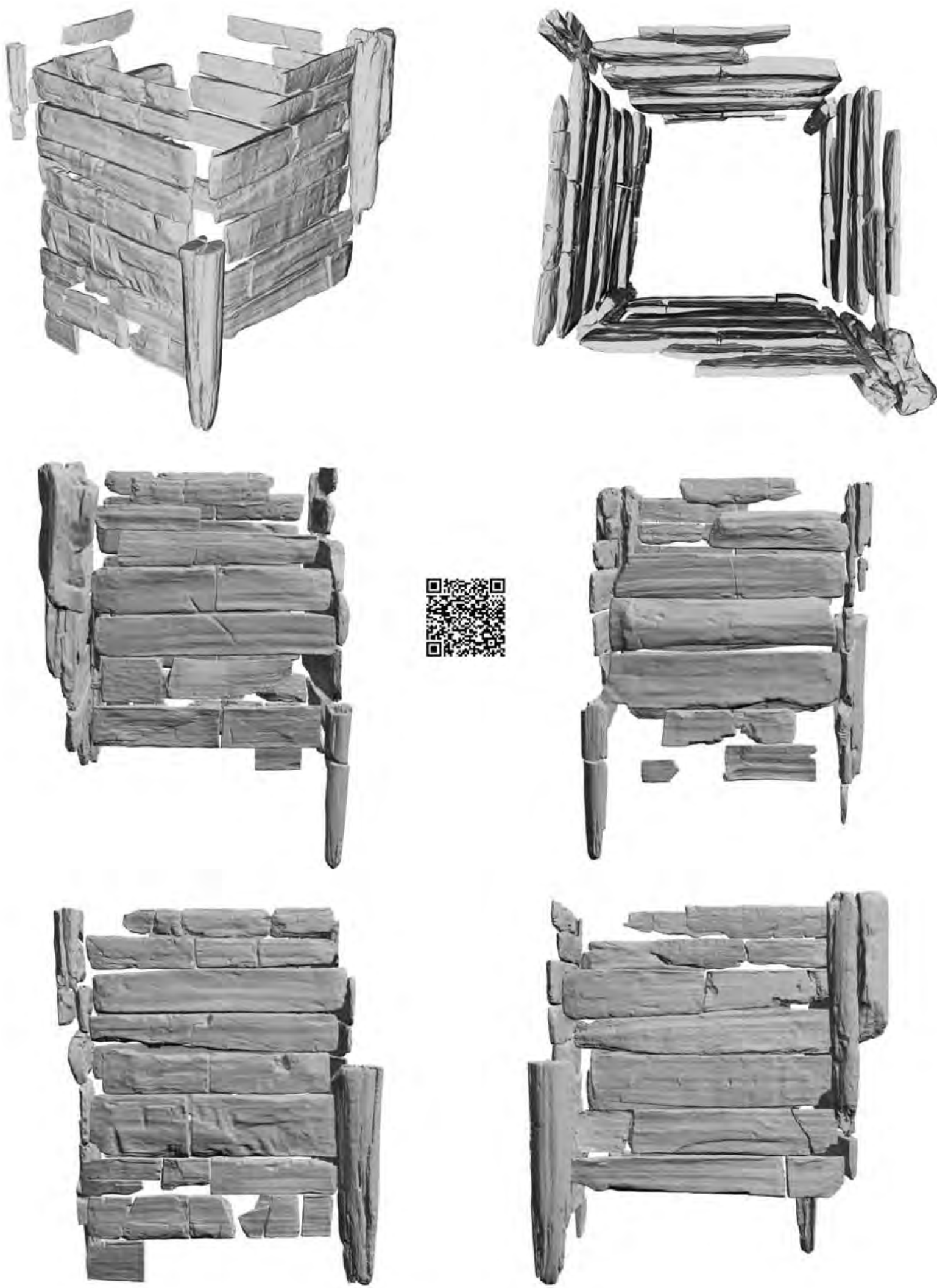

Fig. 10. 3D model of the timber lining. Because of the reflective nature of the surface of the conserved timber, we decided to use 3D photogrammetry instead of a 3D laser scanner. For every fragment of timber, we took approximately 150-200 images using a Nikon D7200 camera with a Nikkor 18-140 mm f/3.55.6G ED VR lens and stationary lights. A 3D model of each fragment was constructed using the photogrammetric software Agisoft Metashape and then a multipart digital model of the wooden well and its structure was constructed according to the original field documentation using Blender 2.8 software (author V. Nosek). - Obr. 10. 3D model dřevěné konstrukce. Protože povrch fragmentů dřev byl díky konzervačnímu procesu značně lesklý, byla pro dokumentaci vybrána metoda obrazové korelace namísto 3D skenování. Fragmenty byly snímány samostatně v sériích 150-200 fotografií za použití Nikonu D7200 s objektivem Nikkor 18-140 mm f/3.5-5.6G ED VR. Pro každý kus dřeva byl prostřednictvím softwaru Agisoft Metashape zvláśt vytvořen 3D model a poté byly tyto modely využity na prostorovou digitální rekonstrukci celé studny v nálezovém stavu podle pưvodní dokumentace za použití softwaru Blender 2.8 (autor V. Nosek). 

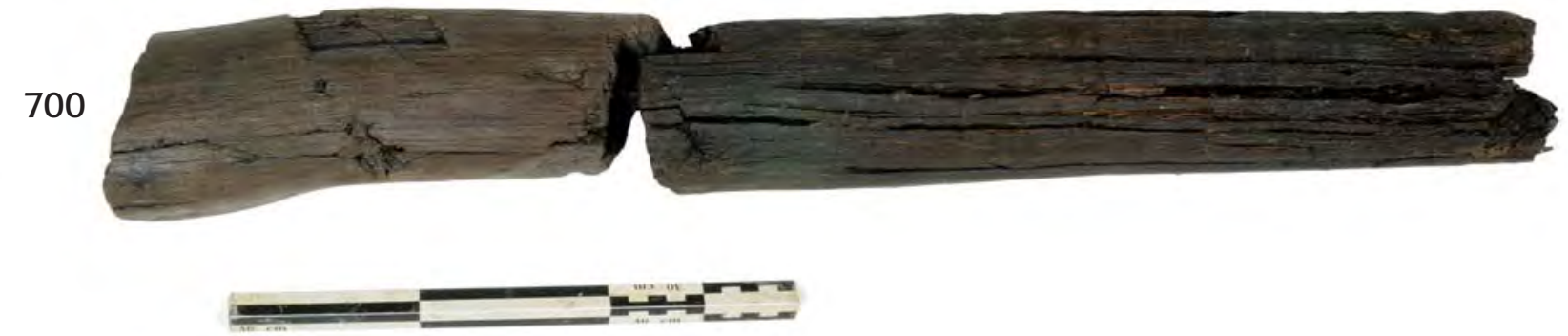

701
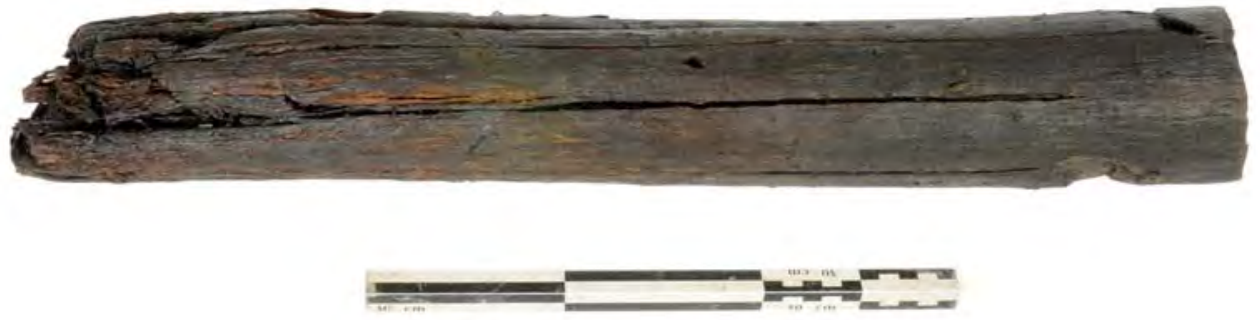

702
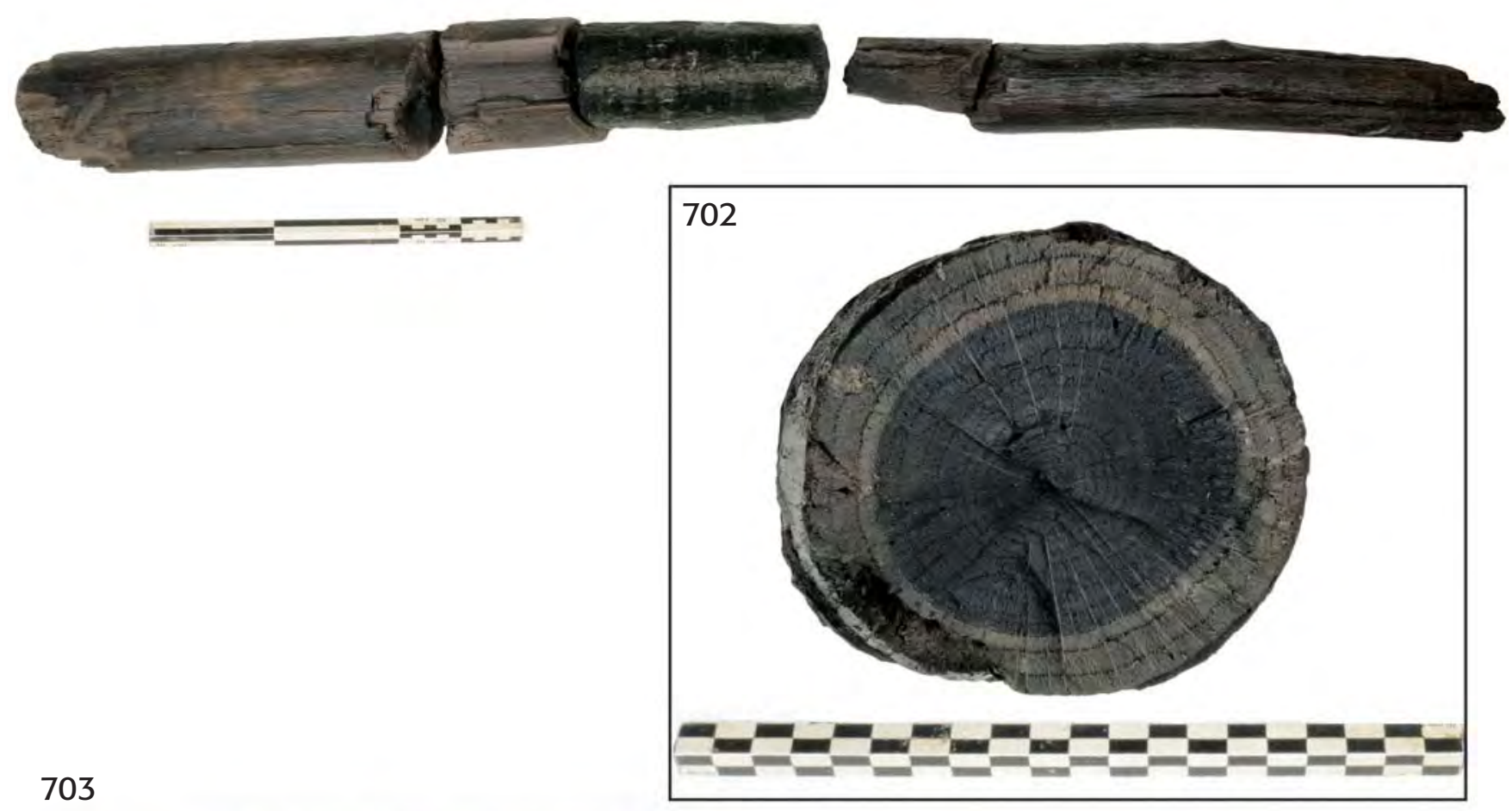

703
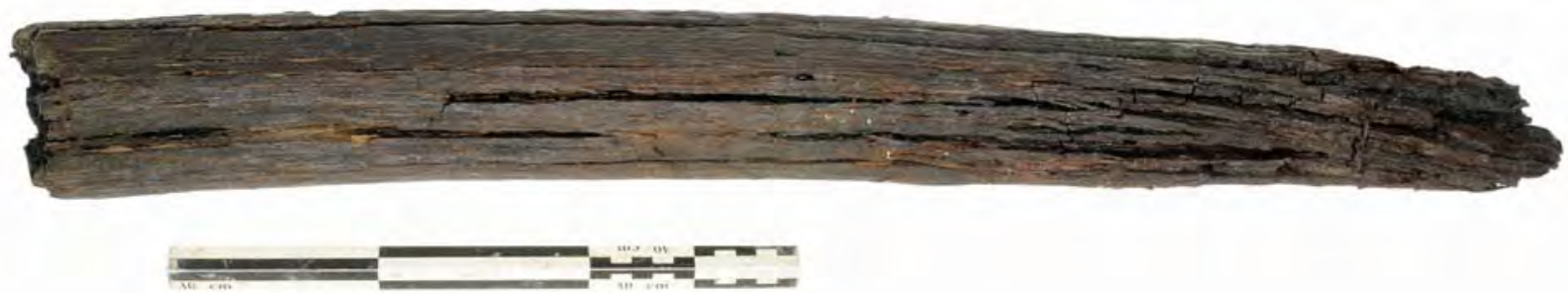

Fig. 11. Individual wooden parts of the well's construction: vertical posts nos. 700-703 (photo by W. Tegel). - Obr. 11. Jednotlivé drevěné části konstrukce studny: svislé kưly č. 700-703 (foto W. Tegel).

The lowermost facies was overlaid by the well-sorted homogenized silty sediment of facies $2(336-299 \mathrm{~cm}$ and 296-282 cm, samples 1 - bottom part, 6 - bottom part,
7, 5, 3 - bottom part, 4 - top part). This material had sedimented in a relatively calm aqueous environment and was probably homogenized by pulling water up 
704
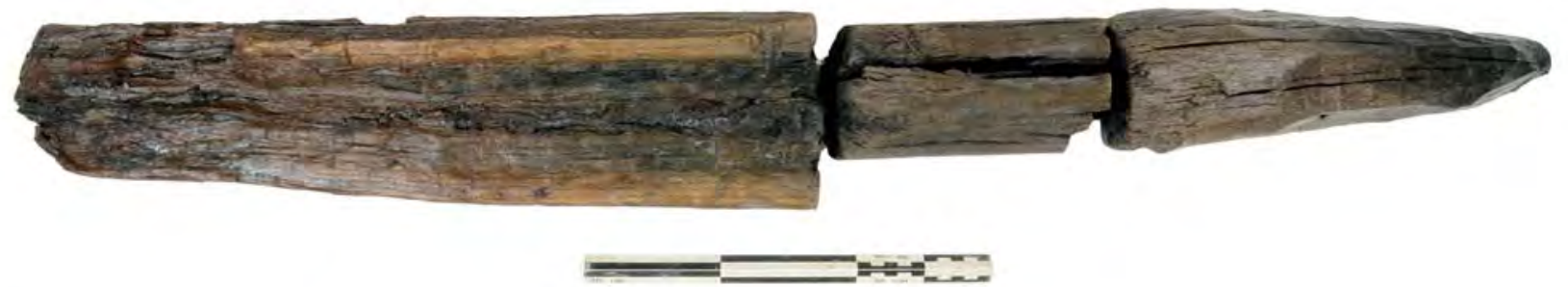

705
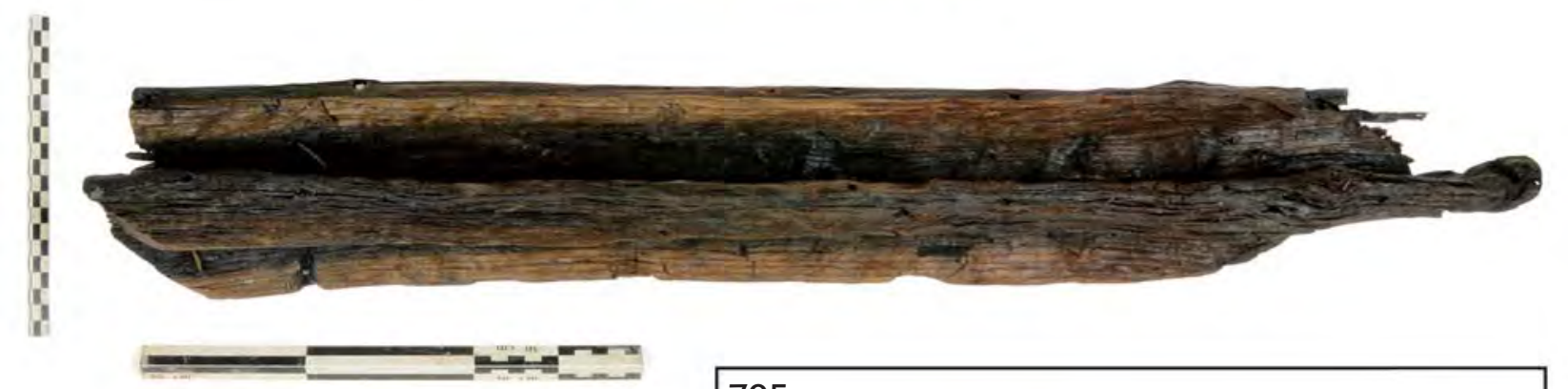

705

706
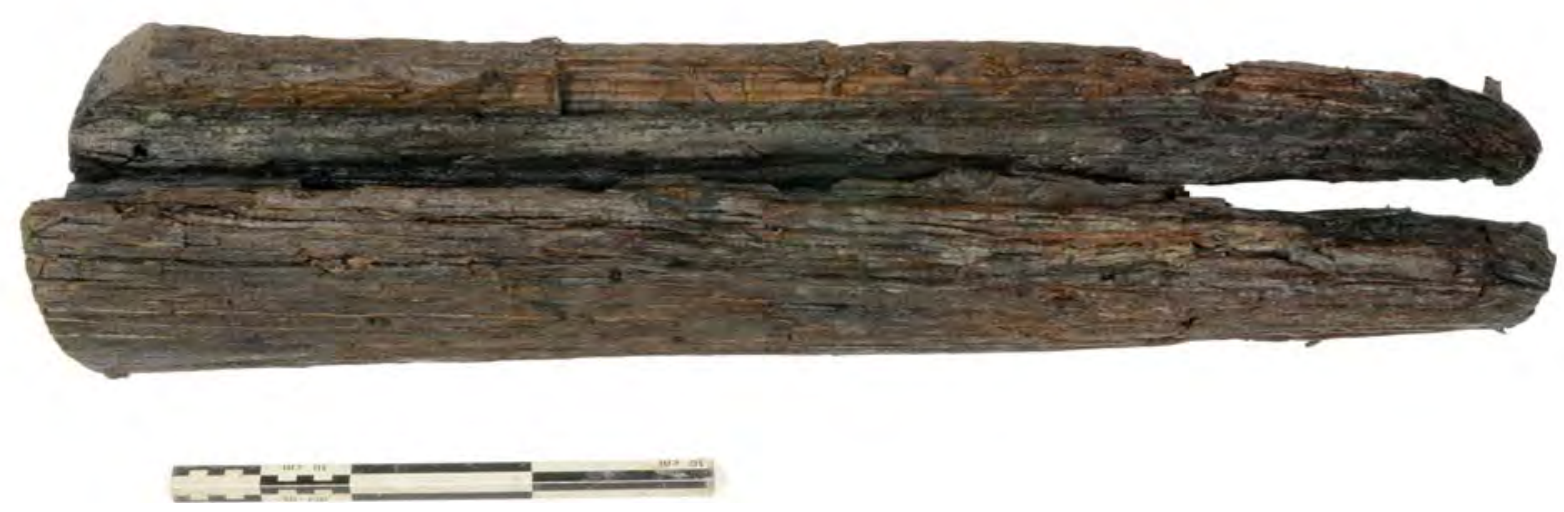

Fig. 12. Individual wooden parts of the well's construction: vertical post no. 704 with a pair of grooves and a worked point and vertical posts nos. 705-706 with grooves (photo by W. Tegel). - Obr. 12. Jednotlivé dřevěné části konstrukce studny: svislý kül č. 704 s párem drážek a opracovaným hrotem a svislé kủly č. 705-706 s drážkami (foto W. Tegel).

from the well. The source material were older floodplain sediments and also aeolic dust that fell into the open well. Bioturbation in this facies was only observed in the case of sample 5 and for the bottom part of sample 3 , which were intruded by plant roots from the superincumbent facies 3 .
Facies 3 (299-298 cm, middle part of sample 3) represents a redeposited and bioturbated sandy-silty material with charcoal pieces evidencing anthropogenic activities in the neighbourhood of the well. Traces of growing plants prove that there was no water column at the bottom of the well when this facies emerged. 


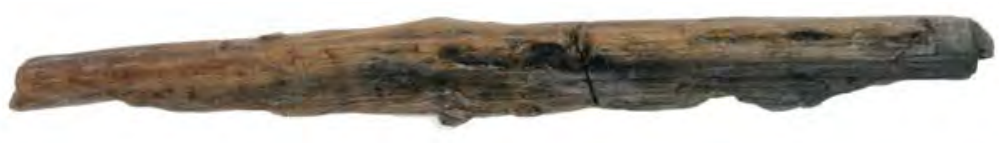

707
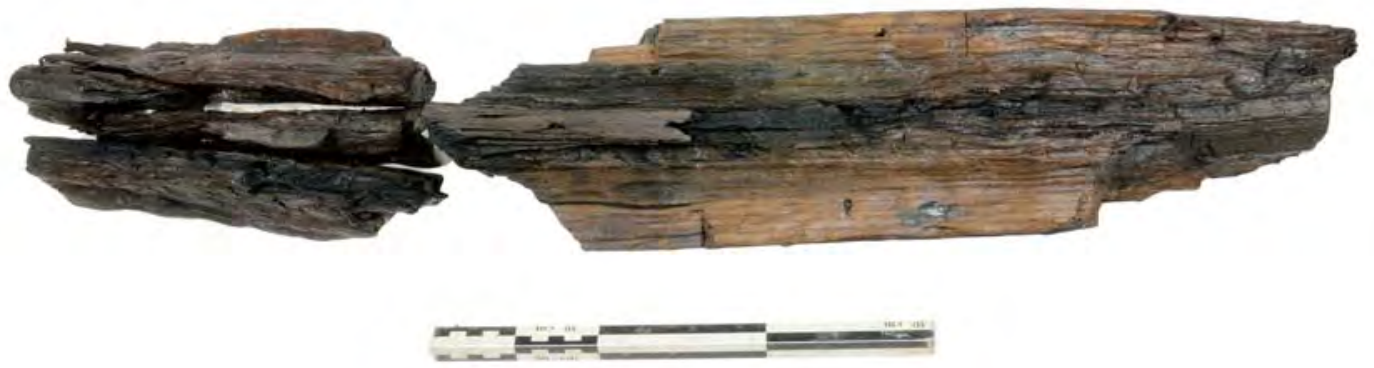

708
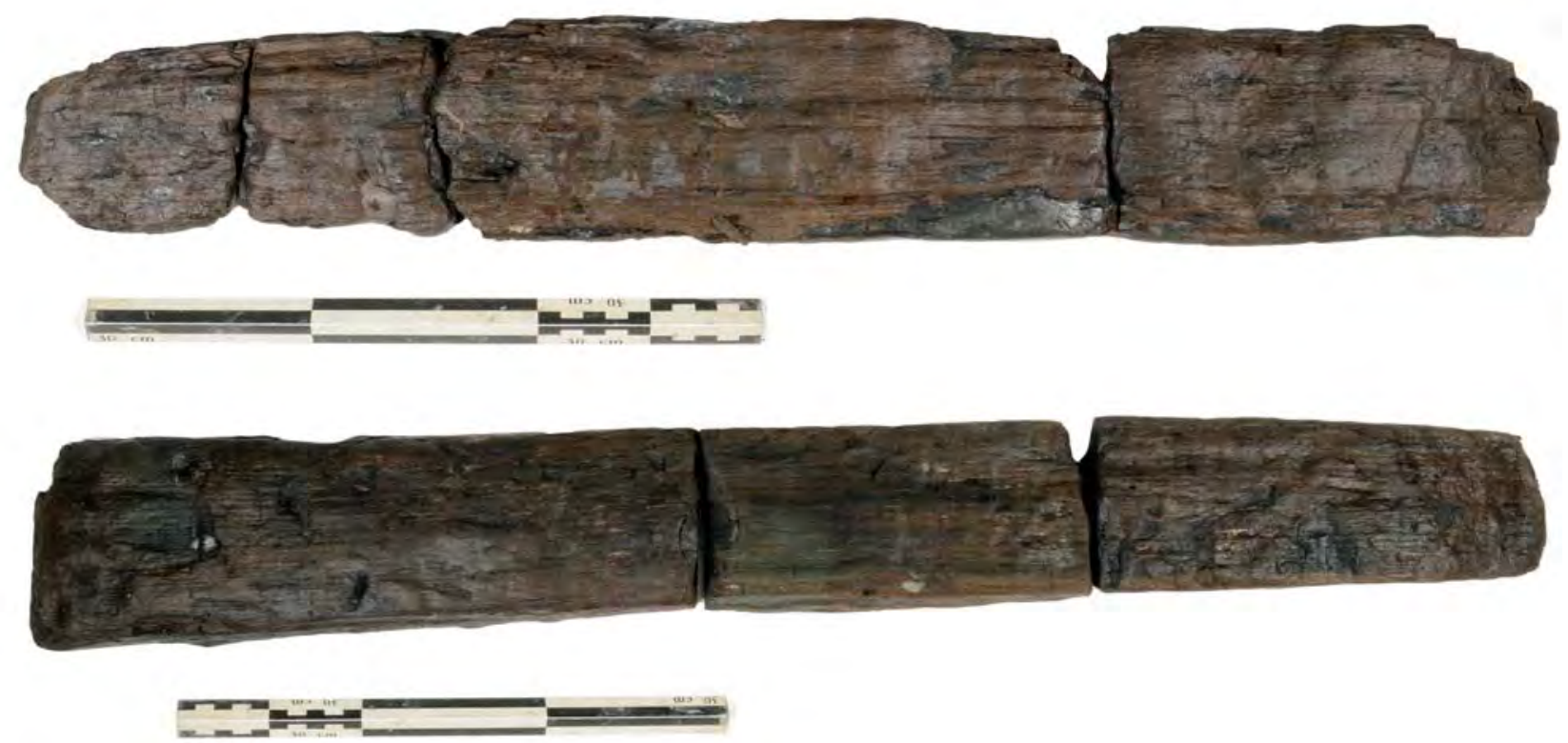

Fig. 13. Individual wooden parts of the well's construction: vertical post no. 707 with a pair of grooves and radially split wood nos. 708-709 with bevelled edges on both sides (photo by W. Tegel). - Obr. 13. Jednotlivé drevěné části konstrukce studny: svislý kül č. 707 s párem drážek a radiálně štípané dřevo č. 708-709 se zkosenými konci na obou stranách (foto W. Tegel).

The following layer was facies $4(298-297 \mathrm{~cm}$, uppermost part of sample 3), which overlays facies 3 . It was represented by a pale heterogeneous silty material containing large amounts of dark soil aggregates. The material probably landed in the well as a result of intrusion and redeposition of part of the surface soil horizon from the neighbourhood of the well and its intermingling with fluvial silts in which the well was dug. The top of the sequence was again represented by the silty sediment of facies 2 (top part of sample 4) with the inclusion of facies 5 (bottom part of sample 4).

Facies 5 (297-295 cm) was characterized by fine lamination given by alternating silt and fine clayey silt, which was an indication of a periodic sedimentation process. This poses the question whether this process was caused by the way the well was utilized or whether it resulted from meteorological phenomena. The silty sediment of these facies attested to the recurrent presence of water in the well. Facies 4 did not exhibit any traces of bioturbation. It means that the well must have been again filled with water within a relatively short period of time, which did not allow for the development of vegetation cover on the surface of facies 4 .

The matrix of facies $6(282-275 \mathrm{~cm}$, samples 2 , 8A and $8 \mathrm{~B}$ ) was composed of coarse silt with an admixture of decomposed organic matter. The facies most probably emerged by the washing down of the original fluvial silt. At the time when this layer sedimented, the water was supposedly polluted by plant remains, which was indicated by the presence of partly decomposed plant tissues. The large amount of organic matter most probably resulted in eutrophication of the water. Increased

Fig. 14. Individual wooden parts of the well's construction: radially split wood nos. 716-718 with bevelled edges on both sides (photo by W. Tegel). - Obr. 14. Jednotlivé dřevěné části konstrukce studny: radiálně štípané dřevo č. 716-718 se zkosenými konci na obou stranách (foto W. Tegel). 
716
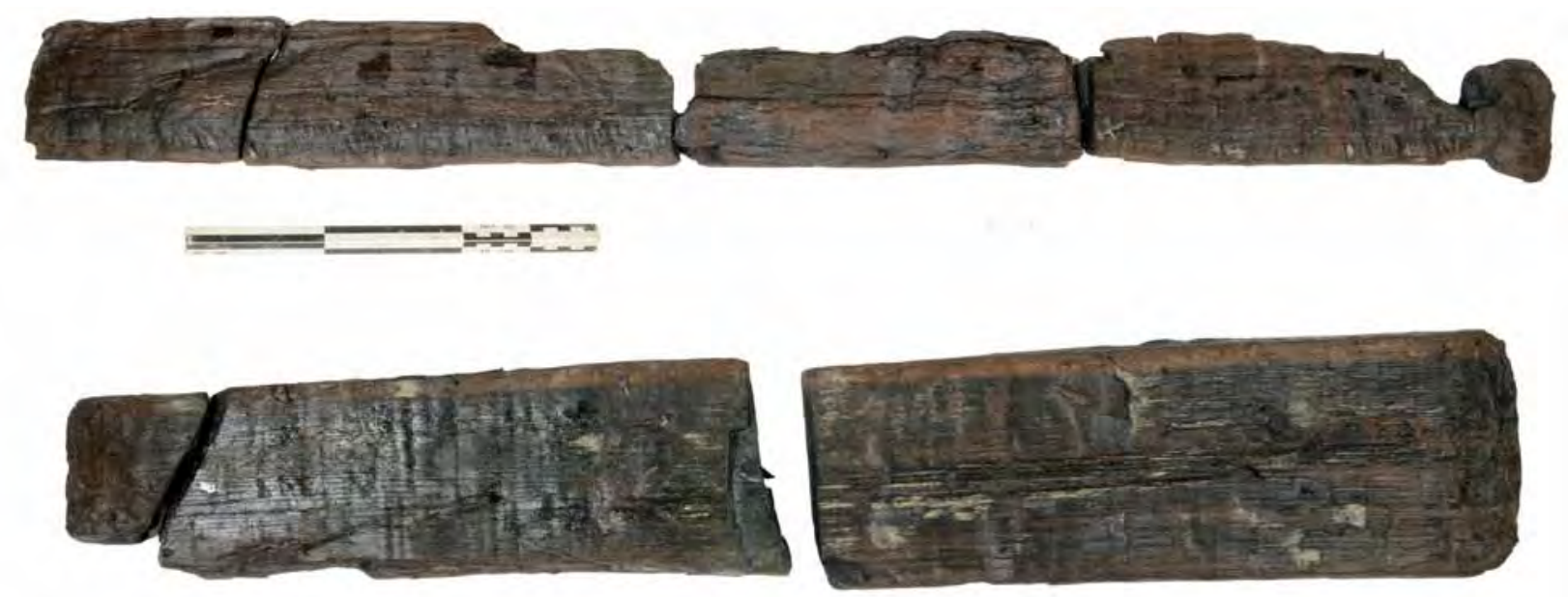

717
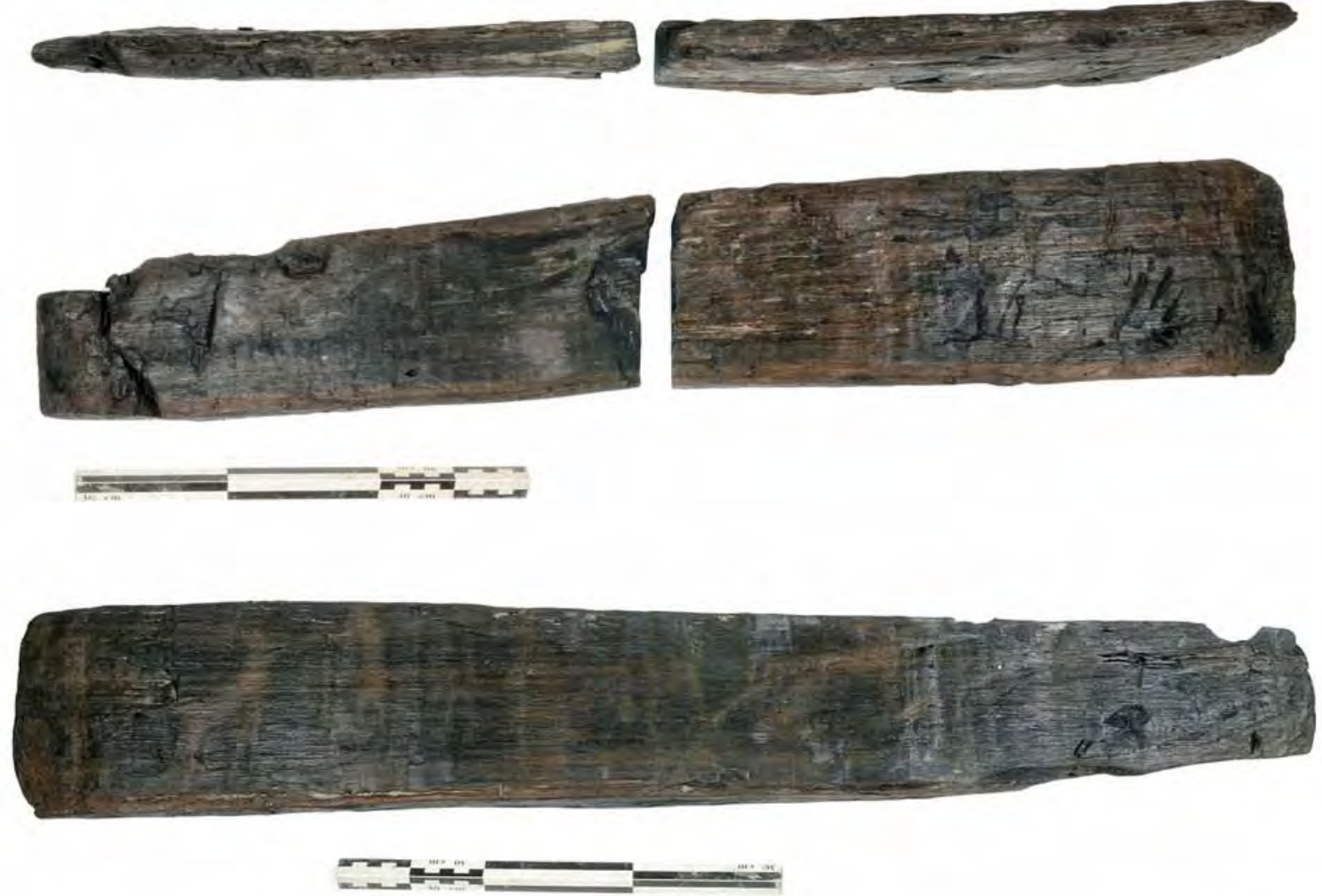

718
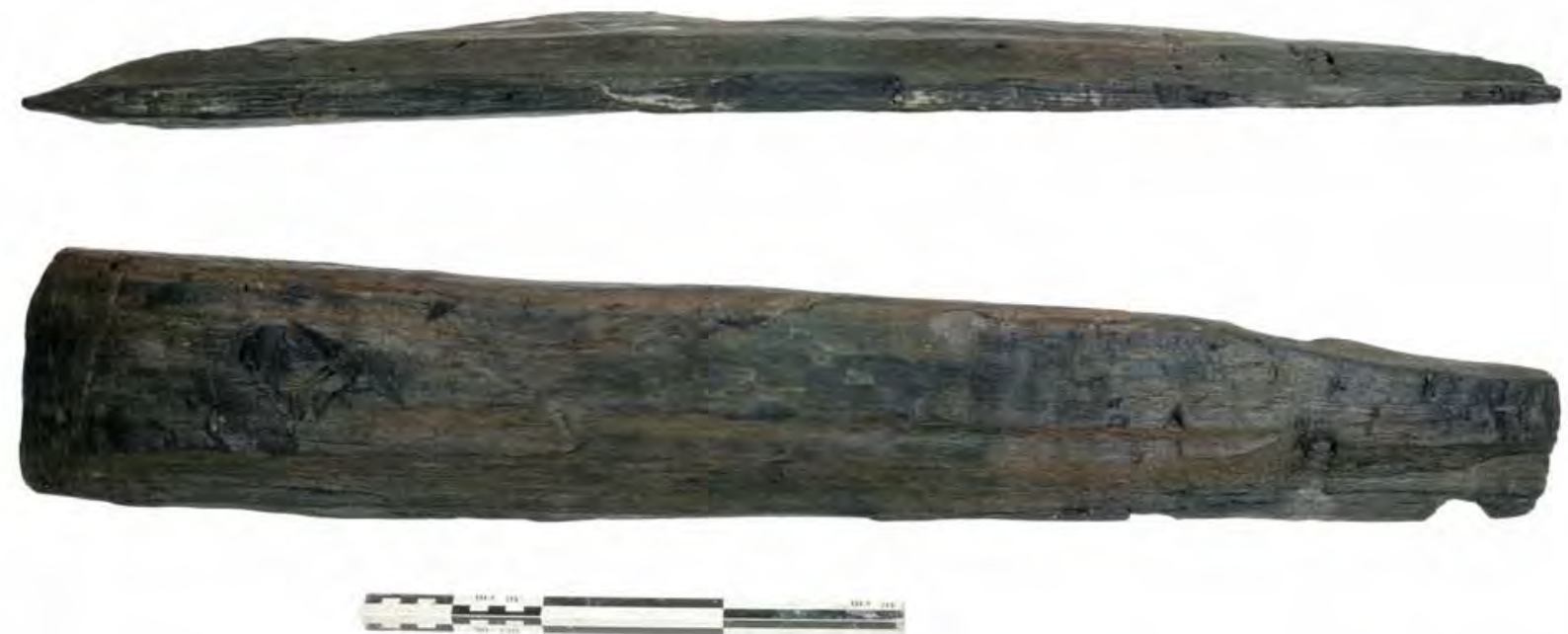

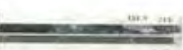




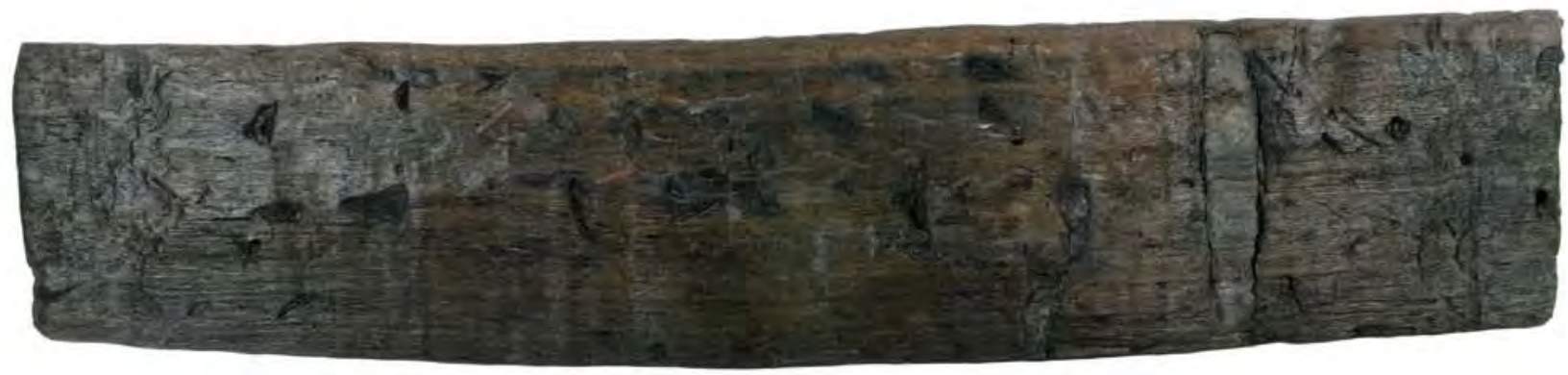

719
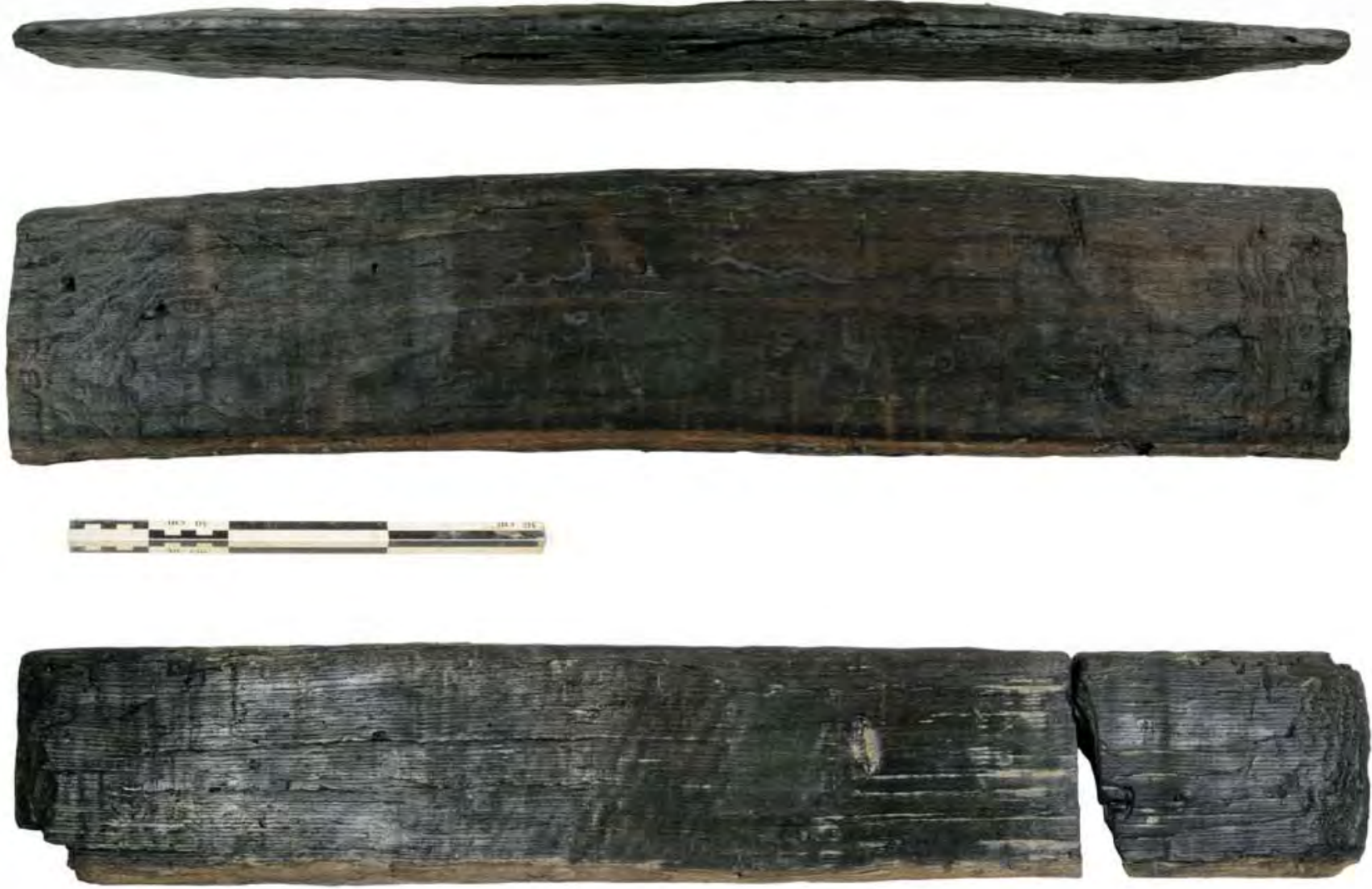

720
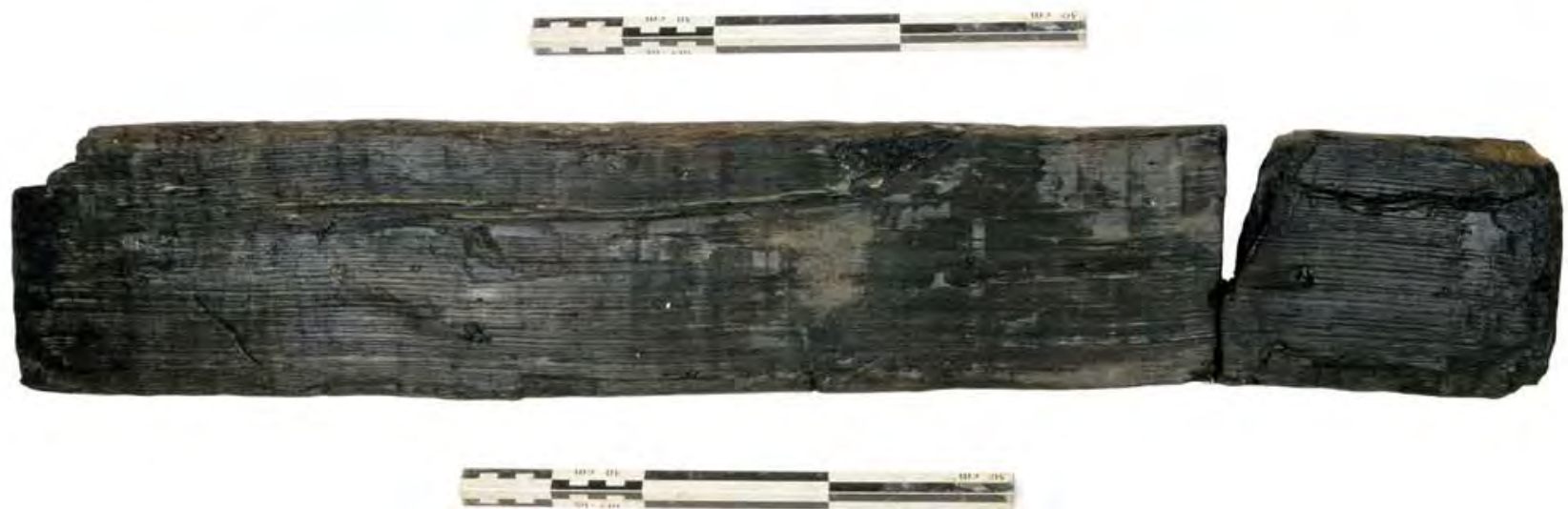

Fig. 15. Individual wooden parts of the well's construction: radially split wood nos. 719-720 with bevelled edges on both sides (photo by W. Tegel). - Obr. 15. Jednotlivé drevevené části konstrukce studny: radiálně štípané dřevo č. 719-720 se zkosenými konci na obou stranách (foto W. Tegel).

organic matter content is reflected also by the LOI 550 curve at 270-280 cm (facies 6 and 7).

The deformed fine sand micro-lamination in superposition above facies 6 represents facies $7(275-274 \mathrm{~cm})$.
It might have emerged as a result of repeated usage of the well, although its water was no longer suitable for consumption. An early end of usage of the well was evident with the subsequent facies 8 (samples 9, 10 and 11). 

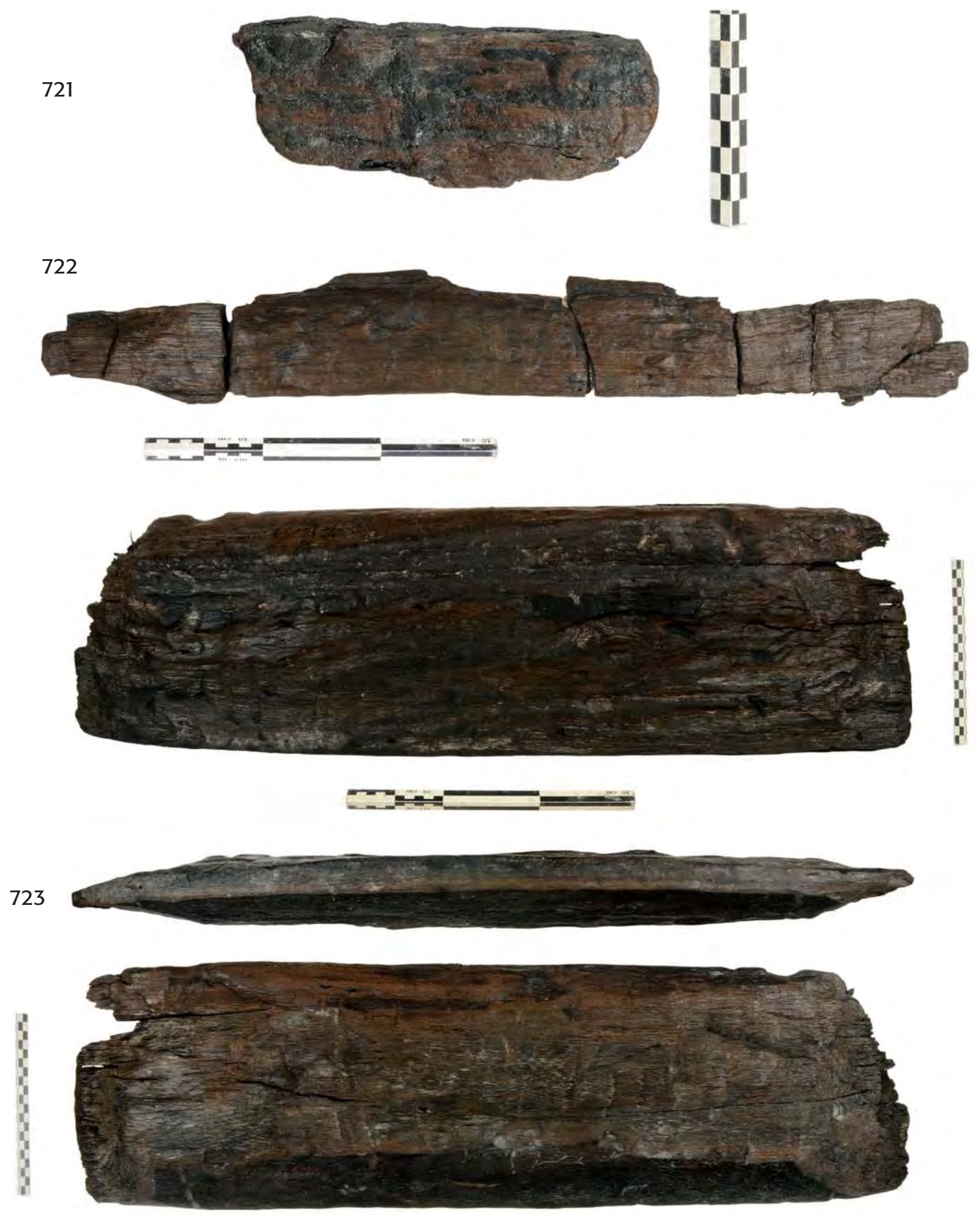

Fig. 16. Individual wooden parts of the well's construction: radially split wood nos. $721-722$ and tangentially split wood no. 723 with bevelled edges on both sides (photo by W. Tegel). - Obr. 16. Jednotlivé dřevěné části konstrukce studny: radiálně štípané dřevo č. $721-722$ a tangenciálně štípané dřevo č. 723 se zkosenými konci na obou stranách (foto W. Tegel). 


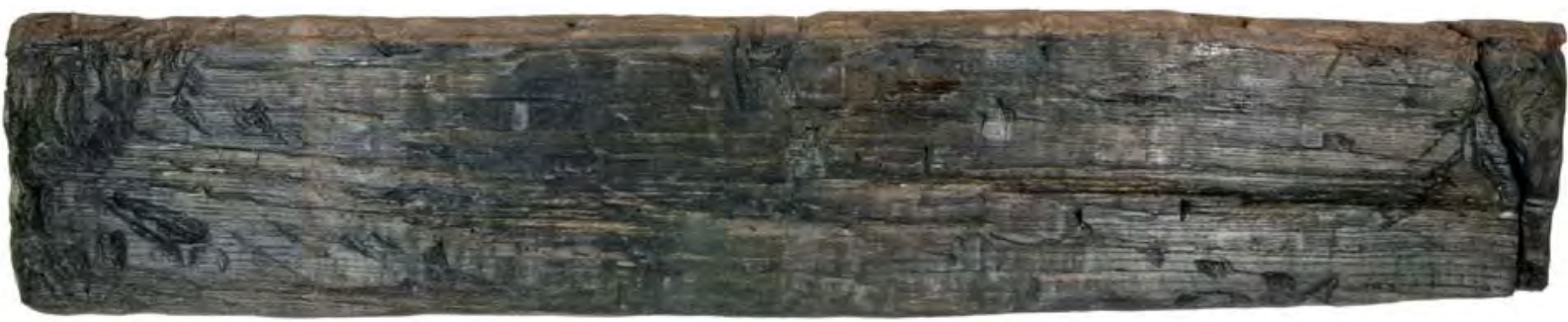

724
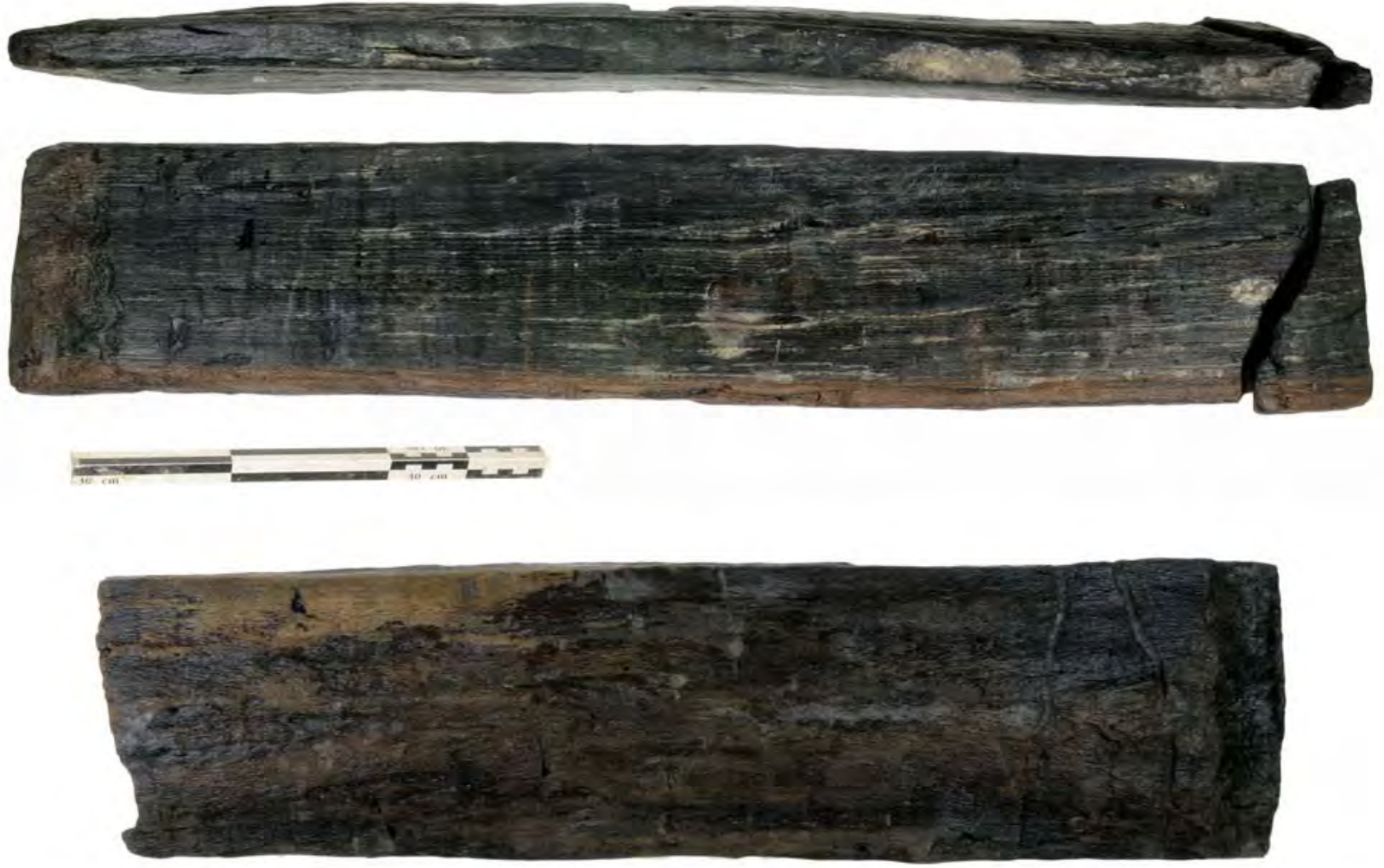

725
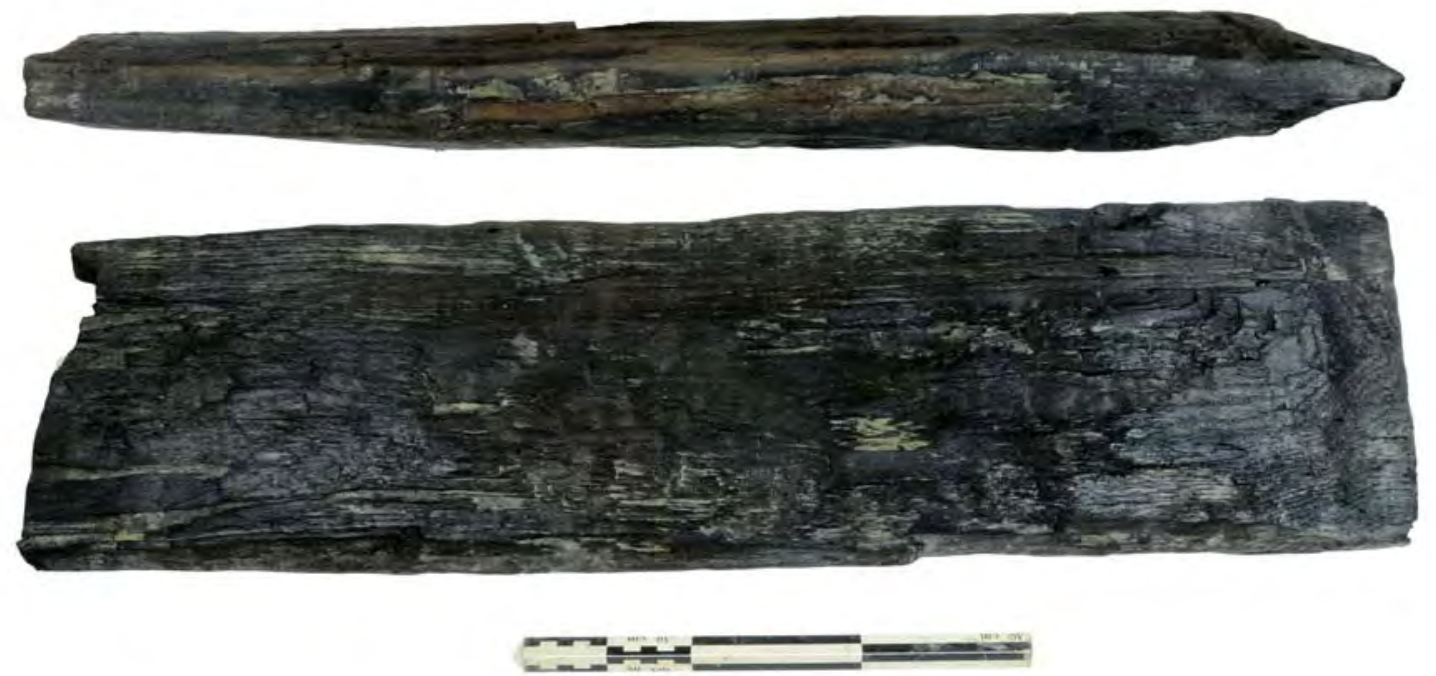

Fig. 17. Individual wooden parts of the well's construction: radially split wood no. 724 with bevelled edges on both sides and tangentially split wood no. 725 with one bevelled edge (photo by W. Tegel). - Obr. 17. Jednotlivé drevěné části konstrukce studny: radiálně štípané dřevo č. 724 se zkosenými konci na obou stranách a tangenciálně štípané dřevo č. 725 se zkoseným koncem na jedné straně (foto W. Tegel).

The curves of all examined proxy indicators in facies 1-7 (depth 280-345 cm) were fluctuating. Weight-dependent magnetic susceptibility (KMass) was increased at depths between 290 and $310 \mathrm{~cm}$. This was possibly caused by the source material or by pedogenesis, which took place during periods when the well was dry. The variability 

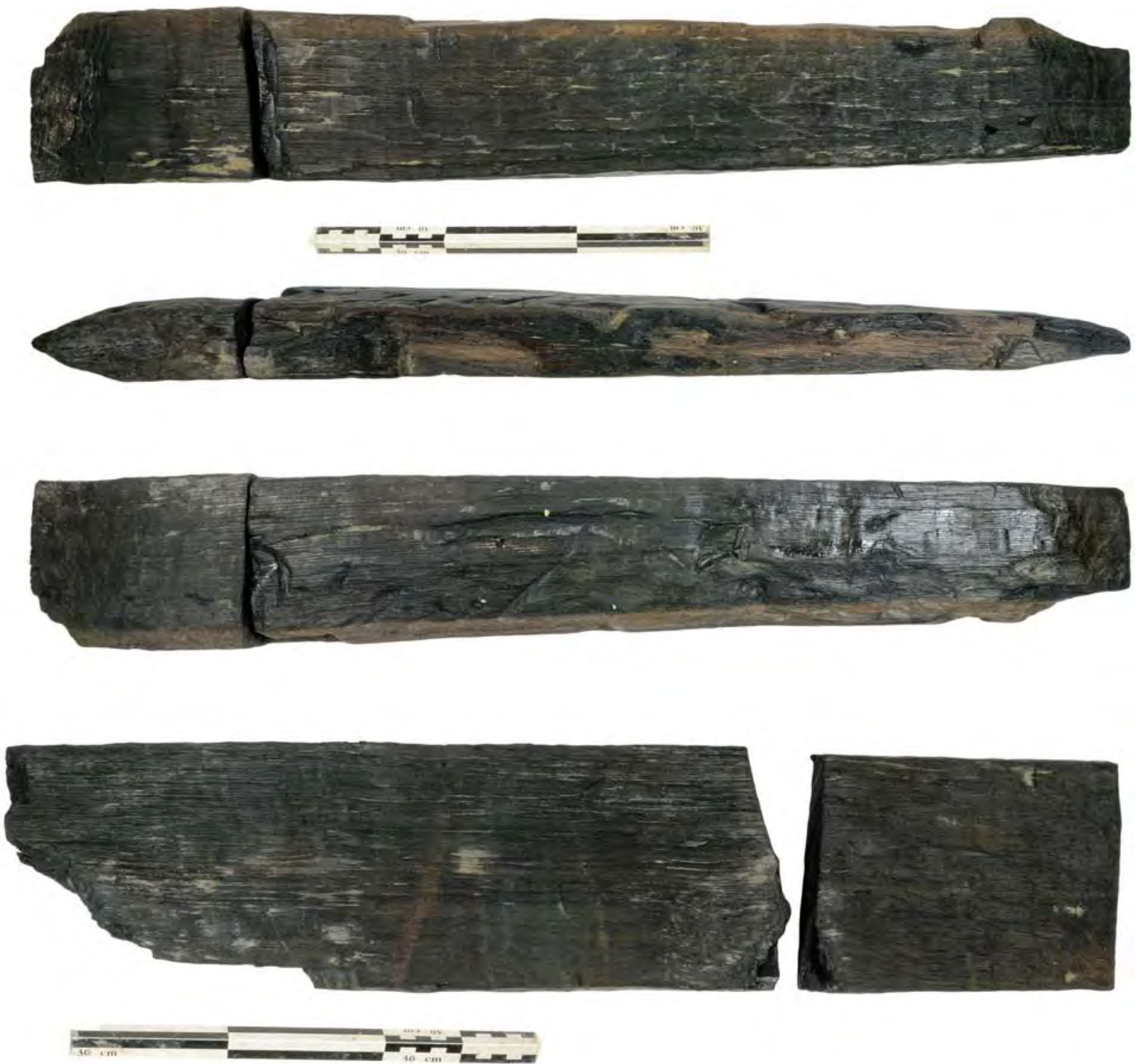

732
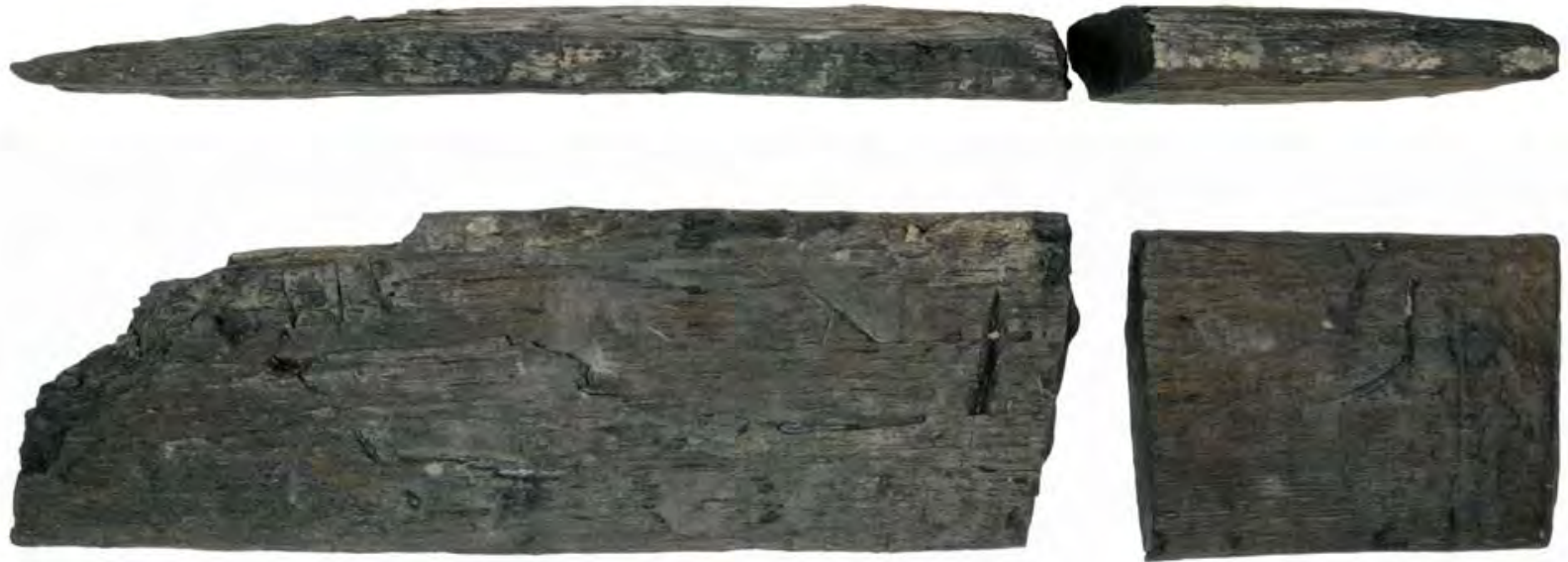

Fig. 18. Individual wooden parts of the well's construction: radially split wood no. 731 with bevelled edges on both sides and radially split wood no. 732 with one bevelled edge (photo by W. Tegel). - Obr. 18. Jednotlivé dřevěné části konstrukce studny: radiálně štípané drevo č. 731 se zkosenými konci na obou stranách a radiálně štípané dřevo č. 732 se zkoseným koncem na jedné straně (foto W. Tegel).

of grain size and the presence of micro-laminae of a coarse sediment were reflected in a fluctuating silicon/aluminium proportion (Si/Al). Phosphorus (P) was present in a relatively low amount, so the well was probably not contaminated by excrements. The values of calcium (Ca) correlate with magnetic susceptibility. 


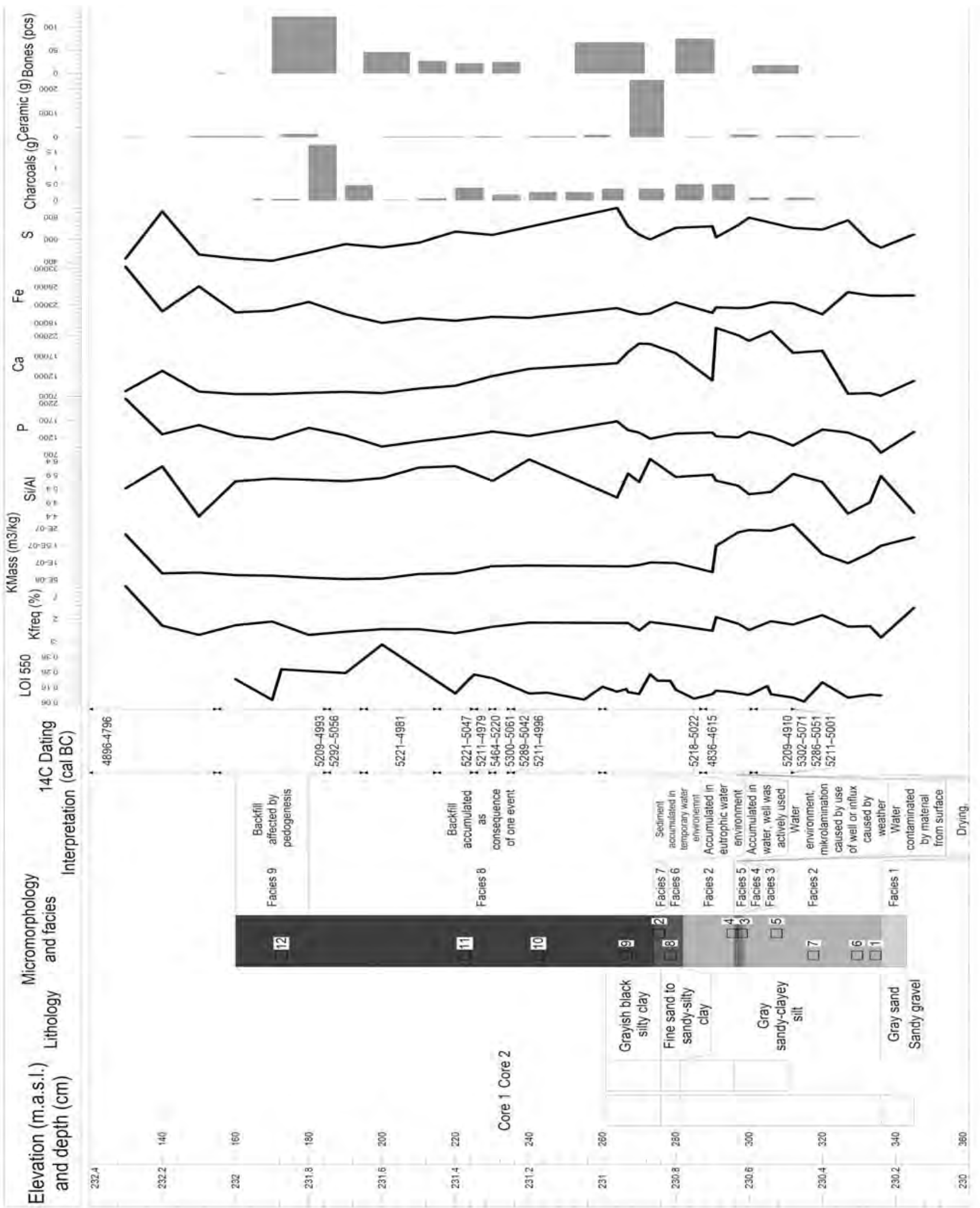

Fig. 19. Lithostratigraphic and facial scheme of the well's infill with the positions of micromorphological samples, their interpretation and dating. - Obr. 19. Litostratigrafické a faciální schéma výplně studny s pozicemi mikromorfologických vzorkü, jejich interpretace a datování.

Facies $8(274-180 \mathrm{~cm})$ was composed of dark coarse silt which contains pale greyish-beige pellets of silty sediment and dark brown humic soil aggregates with passage features. The matrix and soil aggregates probably come from the surrounding surface soil horizon of the well. Pellets originated from the outer sealing of the well, identified during the archaeological excavation. The heterogeneous character of the infill is illustrated also by the oscillating curve of LOI 550 and indicates rapid or even single-event deposition of material (see the 

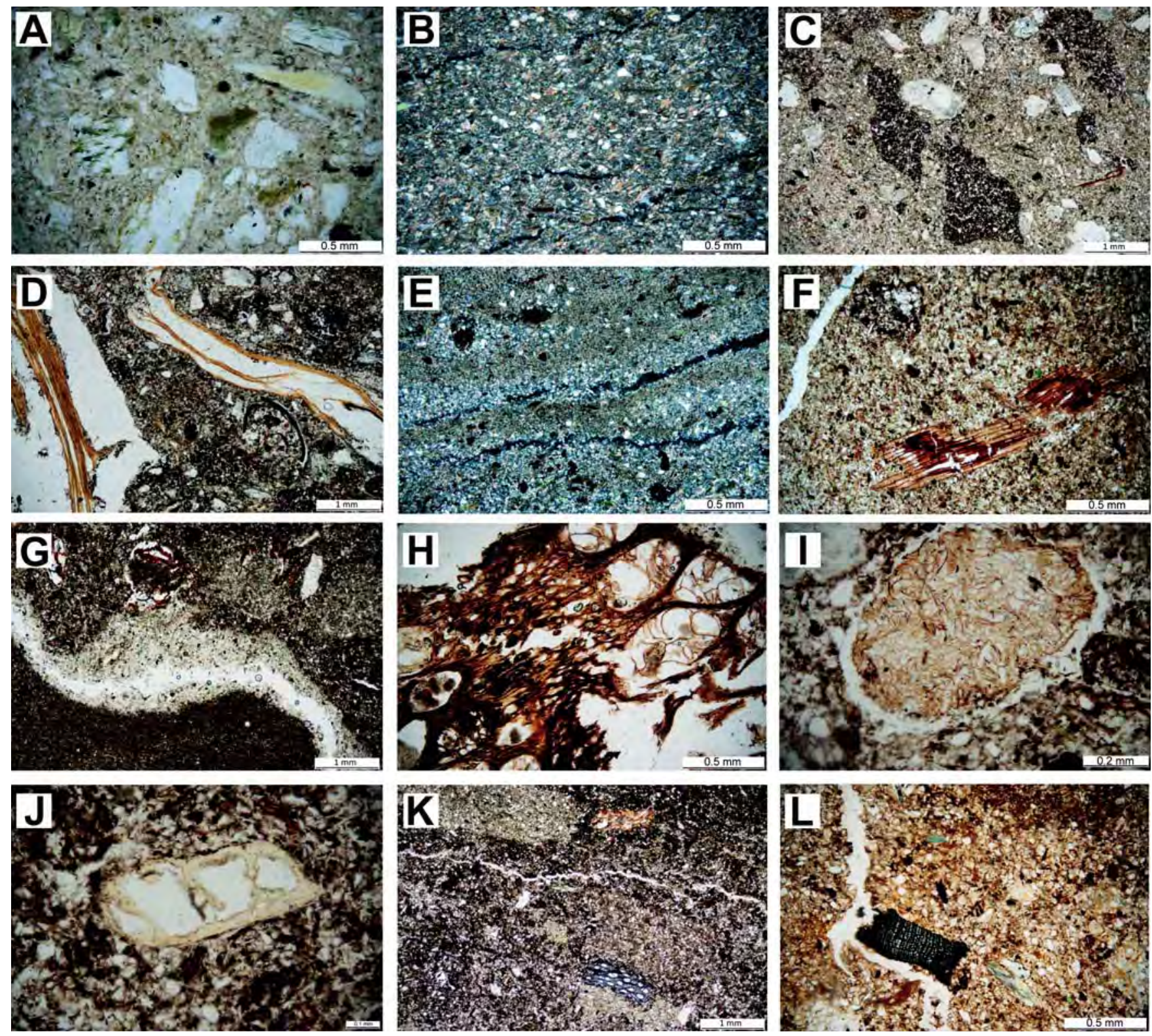

Fig. 20. Thin sections (for location see Fig. 19). A - sample 1, facies 1: poorly sorted sandy sediment composed mostly of quartz grains and fragments of metamorphic rocks (PPL); $\boldsymbol{B}$ - sample 7, facies 2: well-sorted silty sediment, crack microstructure (XPL); $\mathbf{C}$ - sample 3, facies 4: dark brown soil aggregates surrounded by pale groundmass (PPL); $\boldsymbol{D}$ - sample 3, facies 3: silty sandy sediment with an example of plant remains (PPL); $\boldsymbol{E}$ - sample 4, facies 5: silty and clayey silty micro-laminae (XPL); $\boldsymbol{F}$-sample 8, facies 6: well-sorted coarse silt with remains of plant tissue (PPL); $\boldsymbol{G}$ - sample 2, facies 7: deformed sandy micro-laminae surrounded by well-sorted coarse silty sediment (PPL); $\boldsymbol{H}$ - sample 2, facies 7: example of plant remains with internal structure (PPL); I-sample 9, facies 8 : fecal pellet containing plant remains (PPL); $\boldsymbol{J}$-sample 10, facies 8: bone fragment (PPL); $\boldsymbol{K}$-sample 11, facies 8: dark coarse silt containing pale greyish-beige clasts of silty sediment, charcoal fragment with internal structure (PPL); $\boldsymbol{L}$ - sample 12, facies 9: moderately sorted coarse silt, crack microstructure and fragment of charcoal with internal structure (PPL). Photo by K. Adameková. - Obr. 20. Mikrofotografie výbrusových preparátů (přesná lokalizace viz obr. 19). A - vzorek 1, facie 1: slabě vytř́děný pisčitý sediment složený hlavně z minerálních zrn křemene a fragmentü metamorfovaných hornin (PPL); $\boldsymbol{B}$ - vzorek 7, facie 2: dobře vytříděný prachovitý sediment, puklinová mikrostruktura (XPL); C - vzorek 3, facie 4: tmavě hnědý pưdní agregát obklopený světlou základní hmotou (PPL); D vzorek 3, facie 3: prachovito-písčitý sediment se zbytky rostlinných pletiv (PPL); $\boldsymbol{E}$ - vzorek 4, facie 5: prachovité a jillovito-prachovité mikrolaminy (XPL); $\boldsymbol{F}$ - vzorek 8, facie 6: dobře vytř̀iděný hrubě zrnitý prachovitý sediment se zbytky rostlinných pletiv (PPL); G - vzorek 2, facie 7: deformovaná pisčitá mikrolamina obklopená dobre vytříděným hrubě zrnitým prachem (PPL); $\boldsymbol{H}$ - vzorek 2, facie 7: pozůstatek rostlinného pletiva (PPL); I - vzorek 9, facie 8: exkrement obsahujici zbytky rostlin (PPL); $\mathbf{J}$-vzorek 10, facie 8: fragment kosti (PPL); $\boldsymbol{K}$ - vzorek 11, facie 8: tmavý hrubě zrnitý prach obsahujicí světle šedo-béžové klasty prachovitého sedimentu, fragment uhliku s viditelnou vnitřní strukturou (PPL); $\boldsymbol{L}$ - vzorek 12, facie 9: středně vytříděný hrubě zrnitý prach, puklinová mikrostruktura a fragment uhliku s viditelnou vnitřni strukturou (PPL). Foto K. Adameková.

results of radiocarbon dating), which filled the major part of the well. Perhaps the well was backfilled intentionally. At the time of the accumulation of this facies, the well certainly no longer served its original purpose.

Facies 9 (180-160 cm, sample 12) represents a continuation of the well's infill, with evident passage fea- tures and pores created by plant roots. This all attests to intensive pedogenic processes near the surface of the backfilled pit. Facies 8 and 9 exhibit relatively monotonous, low values of magnetic susceptibility, which are increased only in the uppermost part of the section as a result of pedogenic processes. The silicon/aluminium 


\begin{tabular}{|c|c|c|c|c|c|c|c|c|c|c|c|c|c|c|c|c|c|c|c|}
\hline 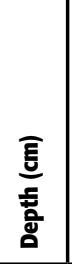 & 产 & 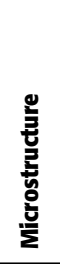 & $\frac{4}{5}$ & 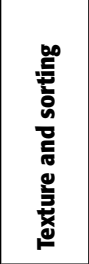 & 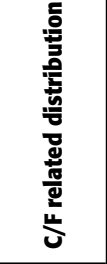 & 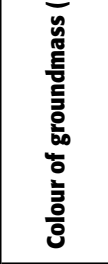 & 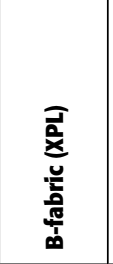 & $\begin{array}{l}\text { Mineral } \\
\text { and rock fragments }\end{array}$ & 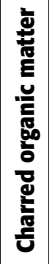 & 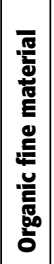 & 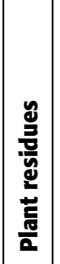 & 岂 & 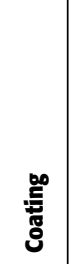 & 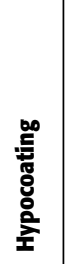 & $\frac{\underline{y}}{\frac{y}{2}}$ & 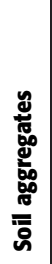 & 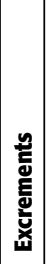 & 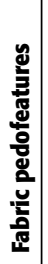 & 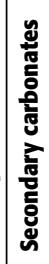 \\
\hline 172.5 & 12 & $\mathrm{Cr}$ & $\begin{array}{l}\mathrm{Cr}, \mathrm{Pl}, \mathrm{Chn}, \\
\text { and Chm, V }\end{array}$ & CS, MS & porphyric & $\begin{array}{c}\text { dark } \\
\text { brown }\end{array}$ & striated & $\begin{array}{l}\text { angular to subangular quartz, } \\
\text { feldspar, micas, fragments } \\
\text { of rocks }\end{array}$ & $*$ & ** & ** & & * clay & & & *** & & $*$ & \\
\hline 222.5 & 11 & M & rare $\mathrm{Chn}$ or $\mathrm{Cr}$ & CS, MS & porphyric & $\begin{array}{c}\text { dark } \\
\text { brown }\end{array}$ & striated & $\begin{array}{l}\text { angular to subangular quartz, } \\
\text { feldspar, micas, fragments } \\
\text { of rocks }\end{array}$ & * & ** & ** & * & & & & *** & & & * \\
\hline 242.5 & 10 & $\mathrm{Ch}$ & $\mathrm{Chn}, \mathrm{Cr}$ & $\mathrm{CS}, \mathrm{MS}$ & porphyric & brown & striated & $\begin{array}{l}\text { angular to subangular quartz, } \\
\text { feldspar, micas, fragments } \\
\text { of rocks }\end{array}$ & & ** & ** & & & & & *** & & $*$ & $*$ \\
\hline 266.5 & 9 & $\mathrm{Ch}$ & $\begin{array}{l}\text { occasional } \\
\text { Chn or } \mathrm{Cr}\end{array}$ & CS, MS & porphyric & brown & striated & $\begin{array}{l}\text { angular to subangular quartz, } \\
\text { feldspar, micas, fragments } \\
\text { of rocks }\end{array}$ & & ** & ** & & & & $* \mathrm{Ca}$ & *** & $*$ & $*$ & $*$ \\
\hline 275.5 & 2 & M & $\begin{array}{l}\text { rare } \mathrm{Cr} \text { or } \\
\mathrm{Chn}\end{array}$ & CS, WS & porphyric & $\begin{array}{c}\text { brownish } \\
\text { gray }\end{array}$ & striated & $\begin{array}{l}\text { subrounded to subangular quartz, } \\
\text { feldspar, micas, glauconite }\end{array}$ & & ** & ** & & & & & & & & \\
\hline 278.5 & 8 & SB & $\mathrm{Cr}, \mathrm{Chn}$ & CS, WS & porphyric & $\begin{array}{c}\text { brownish } \\
\text { gray }\end{array}$ & striated & $\begin{array}{l}\text { subrounded to subangular quartz, } \\
\text { feldspar, micas, glauconite, } \\
\text { amphibole, zircon, fragments } \\
\text { of rocks }\end{array}$ & & ** & ** & & * clay & & ${ }^{*} \mathrm{Ca}$ & ** & & & \\
\hline 295.5 & 4 & M & rare $\mathrm{Cr}$ & S, WS & porphyric & $\begin{array}{l}\text { grayish } \\
\text { beige }\end{array}$ & striated & $\begin{array}{l}\text { subrounded to subangular quartz, } \\
\text { feldspar, micas, glauconite, } \\
\text { fragments of metamorphic rocks }\end{array}$ & & *** & ** & & & ${ }^{*} \mathrm{Ca}$ & & ** & & & \\
\hline 298 & 3 & C & $\begin{array}{l}\text { dominant } \\
\text { Chn and C }\end{array}$ & SS, US & porphyric & $\begin{array}{c}\text { grayish } \\
\text { beige }\end{array}$ & \begin{tabular}{|} 
striated, \\
crystallitic
\end{tabular} & $\begin{array}{l}\text { angular to subangular quartz, } \\
\text { feldspar, micas, glauconite, zircon, } \\
\text { fragments of metamorphic rocks }\end{array}$ & $*$ & *** & *** & & & ${ }^{*} \mathrm{Ca}$ & & ** & & & \\
\hline 307.5 & 5 & M & $\begin{array}{l}\text { rare } \mathrm{Cr} \text { or } \\
\mathrm{Chn}\end{array}$ & $\mathrm{S}, \mathrm{MS}$ & porphyric & $\begin{array}{c}\text { grayish } \\
\text { beige }\end{array}$ & striated & $\begin{array}{l}\text { rounded to subangular quartz, } \\
\text { feldspar, micas, glauconite, } \\
\text { fragments of metamorphic rocks }\end{array}$ & & ** & ** & & & & $* \mathrm{Fe} / \mathrm{Mn}$ & & & & \\
\hline 317.5 & 7 & $\begin{array}{c}\mathrm{Cr} \text { or } \\
\mathrm{M}\end{array}$ & occasional $\mathrm{Cr}$ & S, WS & porphyric & $\begin{array}{c}\text { grayish } \\
\text { beige }\end{array}$ & striated & $\begin{array}{l}\text { rounded to subangular quartz, } \\
\text { feldspar, micas, glauconite, } \\
\text { fragments of metamorphic rocks }\end{array}$ & & ** & ** & & & & & & & & \\
\hline 329.5 & 6 & $\mathrm{Cr}$ & occasional $\mathrm{Cr}$ & $\begin{array}{l}\text { S, WS, } \\
\text { Sa, WS }\end{array}$ & porphyric & $\begin{array}{c}\text { grayish } \\
\text { beige }\end{array}$ & $\begin{array}{c}\text { striated, } \\
\text { grano- } \\
\text { striated }\end{array}$ & $\begin{array}{l}\text { rounded to subangular quartz, } \\
\text { feldspar, micas, amphibole, } \\
\text { glauconite, fragments } \\
\text { of metamorphic rocks }\end{array}$ & & $* *$ & ** & & & & * Fe/Mn & & & & \\
\hline 334.5 & 1 & M & $\begin{array}{c}\text { rare } \mathrm{Chn}_{\mathrm{Cr}} \text { or } \\
\text {. }\end{array}$ & $\begin{array}{l}\text { Sa, PS, } \\
\text { S, WS }\end{array}$ & porphyric & $\begin{array}{l}\text { grayish } \\
\text { beige }\end{array}$ & $\begin{array}{c}\text { striated, } \\
\text { grano- } \\
\text { striated }\end{array}$ & $\begin{array}{l}\text { subrounded to subangular quartz, } \\
\text { feldspar, micas, glauconite, } \\
\text { fragments of metamorphic rocks }\end{array}$ & & ** & ** & & & & & & & & \\
\hline
\end{tabular}

Tab. 3. Results of micromorphological analysis. Microstructure: $S B$ - subangular blocky; $C r$ - crack; $M$ - massive; $V$ - vughy; $P$ - platy; Ch - channel; C - complex. Voids: $\mathrm{Cr}$ - crack; Pl - plane; Chn - channel; Chm - chamber; V - vugh; C - complex packing voids. Texture: S - silt; CS - coarse silt; SS - silty sandy; Sa - sand. Sorting: WS - well sorted; MS - moderately sorted; PS - poorly sorted; US - unsorted. * very few (<5\%); ${ }^{* *}$ common (5-20\%); *** abundant (> 20\%). Tab. 3. Výsledky mikromorfologické analýzy. Mikrostruktura: $S B$ - subangulárně polyedrická; $C r$ - puklinová; $M$ - masivní; $V$ - dutinkovitá; $P$ - destičkovitá; Ch - kanálkovitá; C - komplexní. Póry: Cr - puklinovitý; Pl - plošný; Chn - kanálkovitý; Chm - komůrkovitý; V - dutinkovitý; C - komplexní (póry nakládání). Textura: S - prachovitá; CS - hrubě prachovitá; SS - prachovito-písčitá; Sa - pisčitá. Vytřídění: WS - dobře vytříděný; MS - středně vytř́děný; PS - slabě vytríiděný; US - nevytř́iděný. * občasný (< $5 \%) ; * *$ běžný (5-20\%); *** častý (> $20 \%)$.

proportion (Si/Al) reflects a greater variability of grain size in the bottom part of the section. The values of phosphorus (P) and calcium (Ca), which probably refer to an anthropogenic influence, were increased at the base of facies 8 and in the uppermost part of facies 9 .

Grain size oscillation caused by disturbances of sediments, or possibly a change of source materials, is reflected by the curve of the $\mathrm{Si}$ to $\mathrm{Al}$ ratio. Facies $2-5$ exhibit slightly increased values of frequency-related magnetic (Kfreq) and significantly increased values of weight-dependent magnetic (Kmass) susceptibility above depth of $320 \mathrm{~cm}$. It correlates with increased values of $\mathrm{Ca}$. The last phase of water presence is connected with facies 6 and 7, which exhibits the maximum values of the $\mathrm{Si}$ to $\mathrm{Al}$ ratio (influx of coarser grained sediment) and also increased values of $\mathrm{Ca}$. Increased values of $\mathrm{P}$ and $\mathrm{S}$ are visible at the base of facies 8 and also in facies 9 , which were interpreted as infilling with pedogenesis in the upper part. 


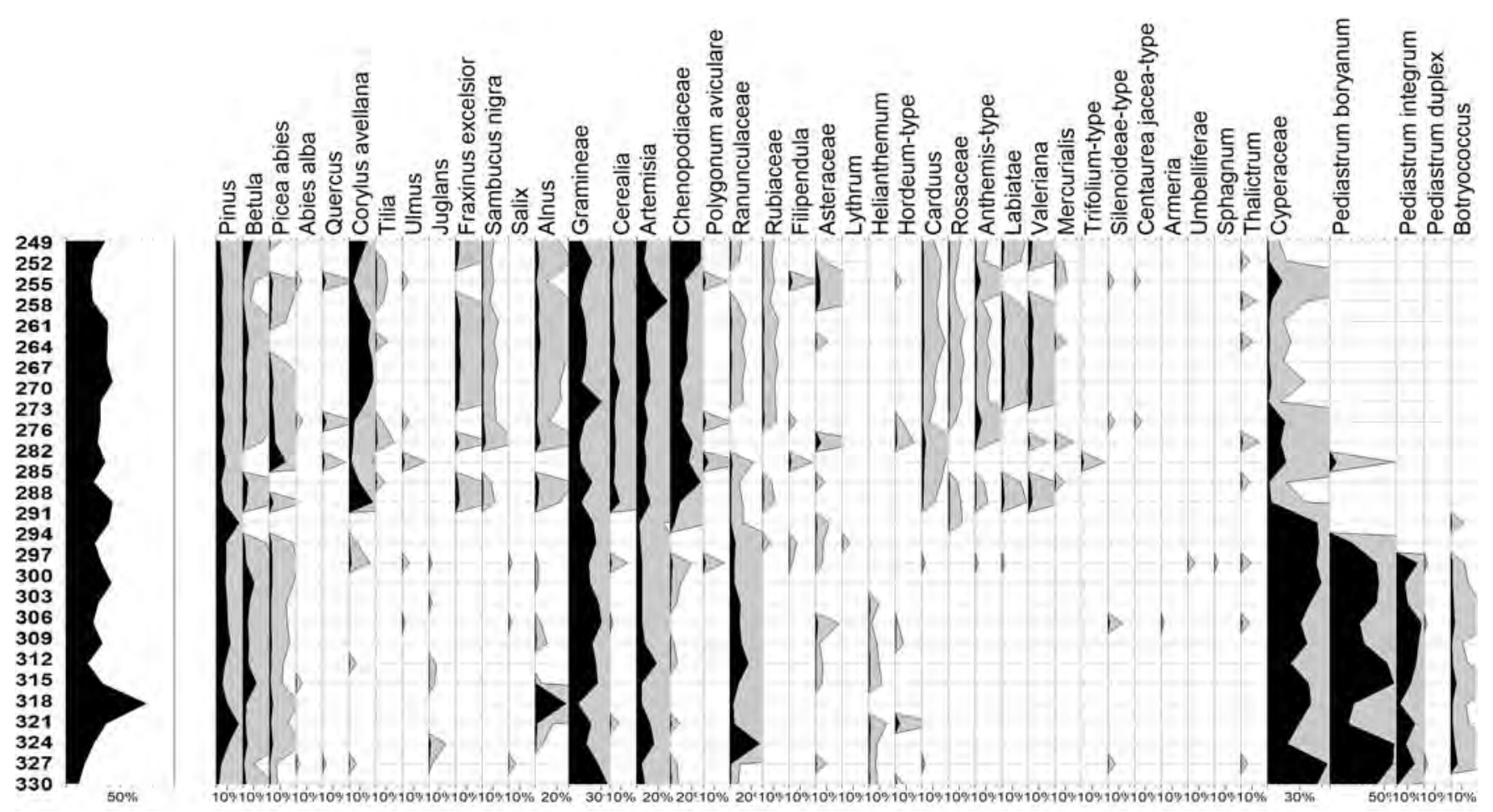

Fig. 21. Simplified percentage pollen diagram. - Obr. 21. Zjednodušený procentuální pylový diagram.

\subsection{Palynology}

Pollen grains were quite well preserved, but in very low concentrations. The pollen record comprised three distinct lithostratigraphic layers (Fig. 21). The bottom, grey sand-clay-dusty layer at a depth of 330-300 cm (facie 2) contained pollen of pine (Pinus), Cyperacae and Gramineae. Spruce (Picea) was common, but broadleaf trees were missing, with the exception of hazel (Corylus) and alder (Alnus). Cereal pollen were rare, too. Possibly present were Pollemonium and Armeria pollen grains, which are highly unusual in Middle Holocene lowlands. Similar is the case of Helianthemum-type pollen, which was very common in the Late Glacial and persists through the Holocene to this day, but it is very rare in the Holocene pollen spectrum. Unusual was the presence of Juglans-type pollen, which can be attributed to Tertiary redeposition. Interesting is the abundance of green algae (Pediastrum boryanum agg., P. integrum and Pediastrum duplex). These green algae are typical of cold, little eutrophicated lakes. Their abundance is very unusual for an artificial water well. This is followed by a short phase of drying at a depth of 300-294 cm (facies 3-5).

The other two layers of fine sand to clay from a depth of 294-275 cm (facies 2) and above it grey-black dusty clay at a depth of 275-249 cm (facies 8) show a different pollen spectrum. Microcharcoals distinctly prevailed in the pollen preparations. They originated from grasses based on their shape, which was elongate, often with visible shapes of grass cells. For this reason, the pollen concentration was very low. The arboreal part of the pollen spectrum amounted to around 30 or $40 \%$. The prevalent taxon was Corylus. Quite common were Pinus, Betula, Picea, Fraxinus and Alnus. Interesting was a low abundance of Quercus, Tilia and Ulmus. This tree com- position generally corresponds with the pollen spectra of natural profiles from the valley of the river Morava, which have been dated to the Middle Holocene. Elder (Sambucus nigra) is element of synanthropic vegetation. A high abundance of Corylus might indicate a locally disturbed woodland, but there is no direct evidence. Grass pollen, Artemisia and Chenopodiaceae were dominant. Together with Carduus, Anthemis-type, Labiateae, Valeriana and Polygonum aviculare-type they represent ruderal vegetation of a settlement. Their diversity was quite high, but by pollen analysis it cannot be determined to the level of species. Carduus-type pollen can be linked to Onopordum acanthium, recorded among plant macroremains. Mercurialis indicates disturbed and fresh bare soil, or possibly gardens. Interesting is a low abundance of cereal pollen, reaching $5 \%$ in the overall spectrum. Even more interesting is that cereal macroremains were present. Based on morphology, size and shape of the poruses (Beug 2004), it corresponds to wheat (Triticum) type. This fact affects the interpretation of natural pollen profiles dated to the Neolithic period and the interpretation of primary anthropogenic indicators, for example cereal pollen.

Cyperaceae pollen was present, but its abundance was lower than in the bottom grey sand-clay-dusty part of the section; green algae were missing. The upper part of the section contained decomposed pollen grains, so the pollen record was missing and the rare fragments of pollen grains could not be used in the interpretation. The change in the palynological record at $294 \mathrm{~cm}$ deep corresponds perfectly to the transition between facies 2 and 3-5. That is, the phase that was interpreted as drying, as evidenced by the sudden loss of algae. Another lithological change at a depth of $275 \mathrm{~cm}$ is not reflected in the palynological record. 


\subsection{Anthracology and xylotomy}

Our analyses of charcoal and wood fragments helped to identify 15 wood taxa (Tab. 4). Analysis of 244 charcoals weighing 5.03 g yielded more interesting and taxonomically more variegated data (Fig. 22). The balanced frequency and weight proportions indicate that the data are representative. This is also attested by the results of the micromorphological analysis of the well infill.

The dominant component of the assemblage was hazel (Corylus), which represented almost one-half of all charcoal pieces analysed. Its high proportion indicates shrubs emerging around the settlement as a result of the first farmers' economic activities (Fig. 23). Shrub stands

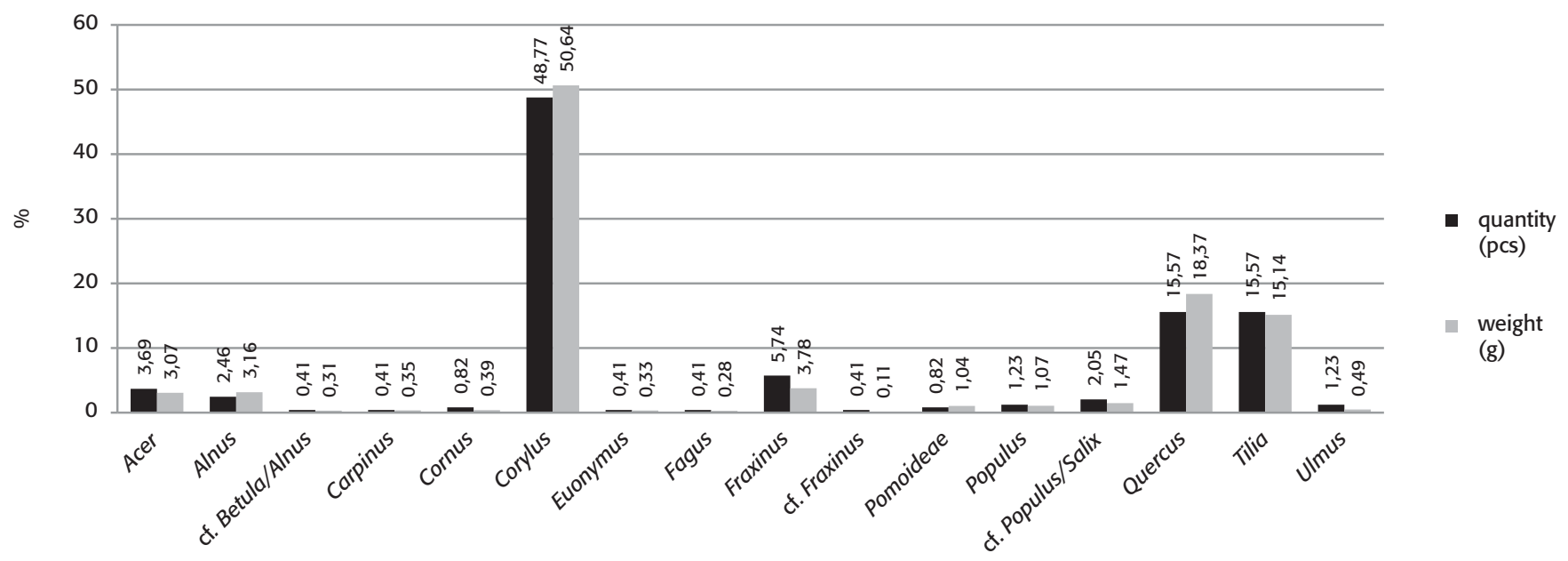

Fig. 22. Results of anthracological analysis. - Obr. 22. Výsledky antrakologické analýzy.

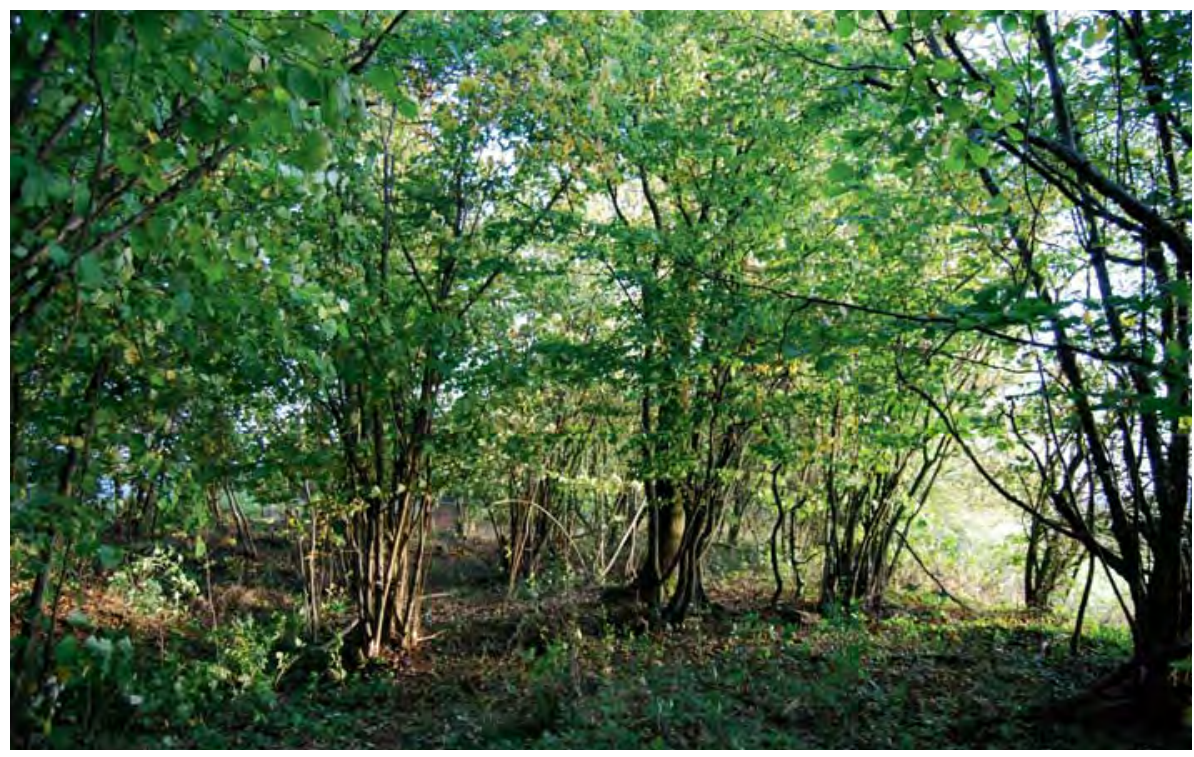

Fig. 23. Hazel stands outside the village of Jarov (dist. Plzeň-South). Photo by P. Kočár. Obr. 23. Stanoviště lísky u obce Jarov (okr. Plzeň-jih). Foto P. Kočár.

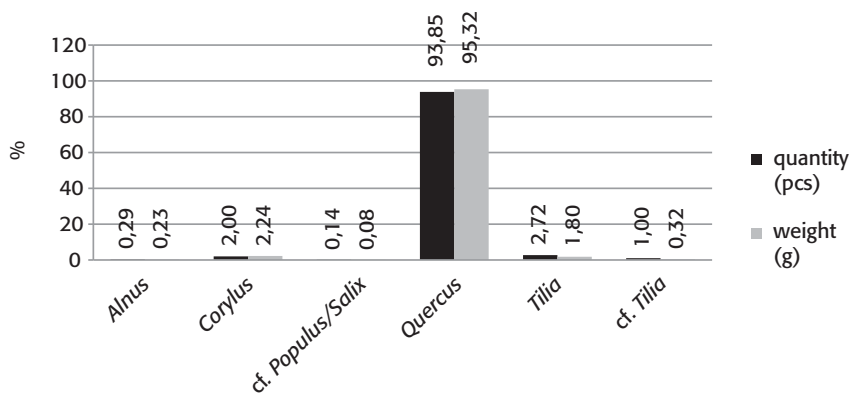

Fig. 24. Results of xylotomic analysis. - obr. 24. Výsledky xylotomické analýzy. were usually adjacent to forest-free spaces within settlement areas. Other taxa were oak (Quercus) and lime (Tilia; 16\%), ash (Fraxinus; 6\%), maple (Acer; 4\%) and alder (Alnus; 3\%), poplar (Populus) and poplar/willow (Populus/Salix, 3\%), and elm (Ulmus; 1\%). Admixed with a frequency of less than 1\% were beech (Fagus), hornbeam (Carpinus) and shrubs (Cornus, Euonymus).

Charcoals of Carpinus and Fagus are the most extraordinary finds. The collection of 20 pieces of Carpinus seeds represents the oldest evidence from Czechia (5464-5220 BC; Tab. 1). Carpinus was detected at Neolithic sites in the Czech Republic in 22 cases. Higher concentrations of Carpinus charcoals are known from the sites in the eastern part of the Czech Republic, 


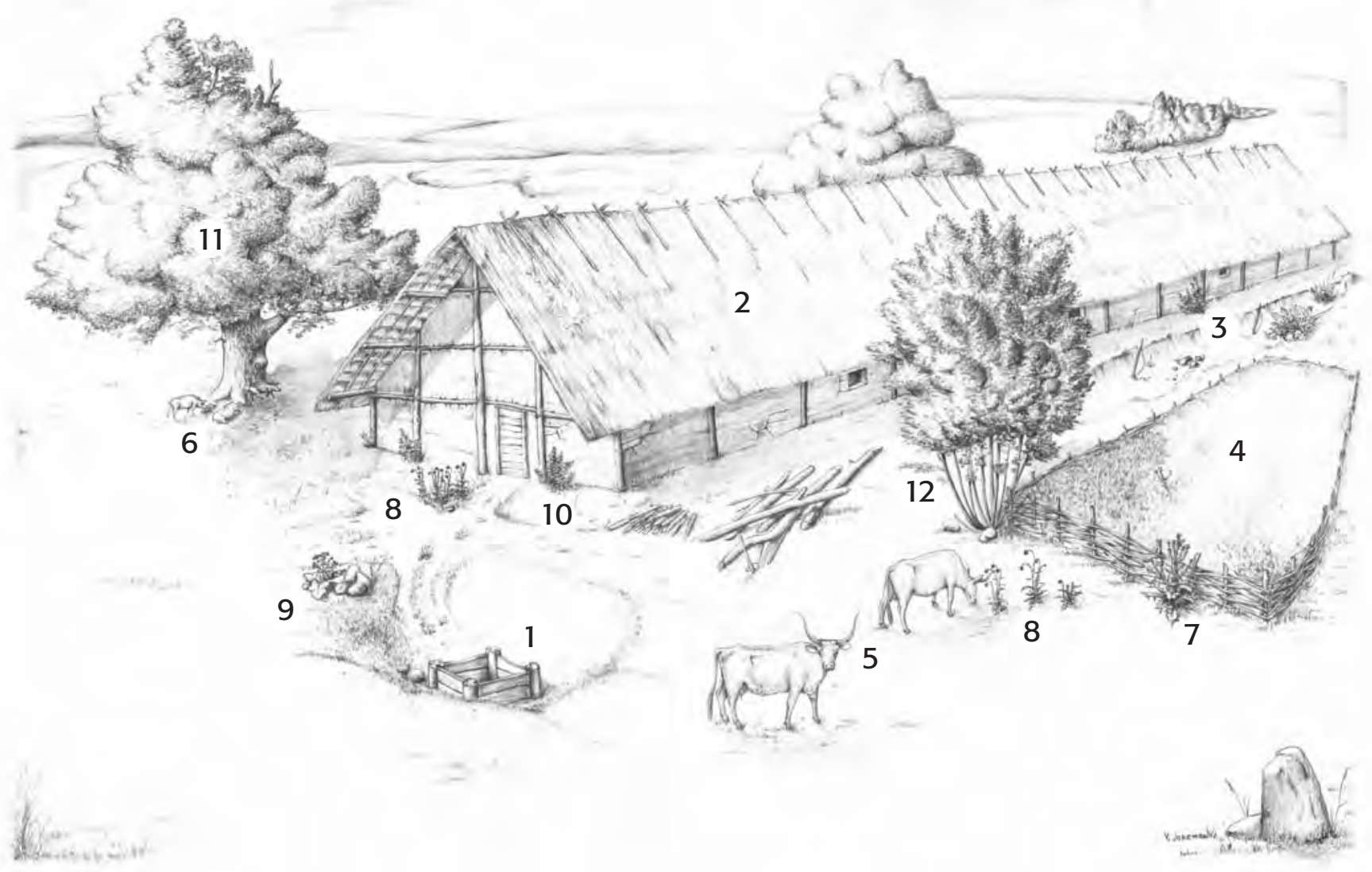

Fig. 25. Drawn reconstruction of the landscape in the vicinity of the Uničov well: $\mathbf{1}$ - wooden well; $\mathbf{2}$ - 'longhouse'; $\mathbf{3}$ - building pit; $\mathbf{4}$ - field; $\mathbf{5}$ - Bos taurus; $\mathbf{6}$ - Sus domesticus; $\mathbf{7}$ - Onopordum acanthium; 8 - Carduus nutans; $\mathbf{9}$ - Arctium nemorosum; 10 - Urtica sp.; 11 - Quercus sp.; 12 - Corylus avellana (author V. Jarema). - Obr. 25. Kresebná rekonstrukce krajiny v okolí uničovské studny: $\mathbf{1}$ - studna s drevěnou konstrukci; $\mathbf{2}$ - dlouhý dům; $\mathbf{3}$ - stavební jáma; $\mathbf{4}$ - pole; $\mathbf{5}$ - Bos taurus; $\mathbf{6}$ - Sus domesticus; $\mathbf{7}$ - Onopordum acanthium; $\mathbf{8}$ - Carduus nutans; $\mathbf{9}$ - Arctium nemorosum; 10 - Urtica sp.; 11 - Quercus sp.; 12 - Corylus avellana (autor V. Jarema).

\begin{tabular}{|c|c|c|c|c|c|c|c|c|c|c|c|c|c|c|c|c|c|c|c|c|c|c|c|c|c|c|}
\hline \multirow{2}{*}{ 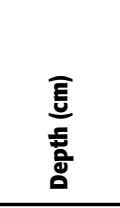 } & \multirow{2}{*}{ 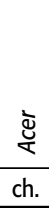 } & \multicolumn{2}{|c|}{$\stackrel{\frac{y}{2}}{\frac{s}{\alpha}}$} & \multirow{2}{*}{ 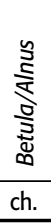 } & \multirow{2}{*}{ 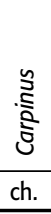 } & \multirow{2}{*}{$\begin{array}{l}\text { હ } \\
\text { ch. } \\
\text { ch. }\end{array}$} & \multicolumn{2}{|c|}{ 胥 } & \multirow{2}{*}{ 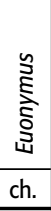 } & \multirow{2}{*}{$\begin{array}{l}\text { 号 } \\
\text { ch. }\end{array}$} & \multirow{2}{*}{ 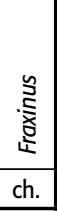 } & \multirow{2}{*}{ 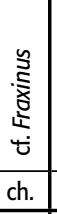 } & \multirow{2}{*}{ 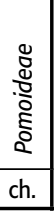 } & \multirow{2}{*}{ 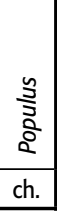 } & \multirow{2}{*}{ 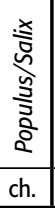 } & \multirow{2}{*}{ 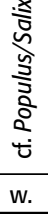 } & \multicolumn{2}{|c|}{ 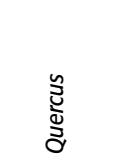 } & \multicolumn{2}{|c|}{ 茎 } & \multirow{2}{*}{$\begin{array}{c}\stackrel{9}{i} \\
\text { t' } \\
\text { w. }\end{array}$} & \multirow{2}{*}{$\begin{array}{l}\stackrel{\checkmark}{\xi} \\
\text { ch. }\end{array}$} & \multicolumn{3}{|c|}{ 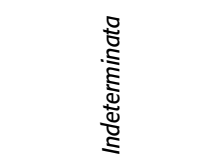 } & \multirow{2}{*}{$\begin{array}{l}\text { 푬 } \\
\text { 으 }\end{array}$} \\
\hline & & ch. & w. & & & & ch. & w. & & & & & & & & & ch. & w. & ch. & w. & & & w. (b.) & w. (d.) & w. & \\
\hline $150-160$ & 1 & & & & & & 2 & & & & & & & & & & 3 & 3 & & & & & & & 2 & 11 \\
\hline $160-170$ & & & & & & & 3 & & & & 1 & & & & & & 1 & & & & & & & & & 5 \\
\hline $170-180$ & & & & & & & 1 & & & & & & & & & & 2 & & & & & & & & & 3 \\
\hline $180-190$ & 1 & & & & & & 5 & & & & & & & & & & 2 & 30 & 2 & & & 1 & & 1 & 5 & 47 \\
\hline $180-230$ & 2 & 3 & & & 1 & 2 & 42 & 10 & 1 & & 5 & & & 1 & 4 & 1 & 13 & 161 & 7 & 1 & & 2 & 12 & 14 & 8 & 290 \\
\hline $200-210$ & & & & & & & 1 & & & & & & & & & & & 5 & & & & & & 3 & & 9 \\
\hline $210-220$ & & & & & & & 2 & & & & & 1 & & & & & 1 & 8 & & & & & & & & 12 \\
\hline $210-260$ & & & & & & & 3 & & & & & & & & & & 2 & 14 & & & & & & 4 & & 23 \\
\hline $220-230$ & 1 & & & 1 & & & 2 & & & 1 & 1 & & 1 & & & & 1 & 15 & 5 & & & & 2 & 2 & 2 & 34 \\
\hline $230-240$ & 1 & 1 & & & & & 2 & & & & 3 & & & & & & 4 & 10 & 3 & 1 & & & & & & 25 \\
\hline $240-260$ & 1 & 1 & 1 & & & & 17 & 3 & & & 2 & & & & 1 & & 2 & 87 & 2 & & & & & 9 & & 126 \\
\hline $260-280$ & 1 & & & & & & 10 & & & & & & 1 & & & & 2 & 51 & 4 & 1 & & & 4 & 2 & & 76 \\
\hline $280-300$ & 1 & & & & & & 15 & & & & & & & & & & 5 & 149 & 8 & 7 & & & 5 & 11 & & 201 \\
\hline $300-325$ & & & & & & & 4 & & & & & & & & & & & 53 & 3 & 3 & & & 3 & 12 & & 78 \\
\hline mix & & 1 & 1 & & & & 10 & 1 & & & 2 & & & 2 & & & & 70 & 4 & 6 & 7 & & & 9 & & 113 \\
\hline Total sum & 9 & 6 & 2 & 1 & 1 & 2 & 119 & 14 & 1 & 1 & 14 & 1 & 2 & 3 & 5 & 1 & 38 & 656 & 38 & 19 & 7 & 3 & 26 & 67 & 17 & 1053 \\
\hline
\end{tabular}

Tab. 4. Summary of anthracological and xylotomic analyses (ch. - charcoal; w. - wood; d. - deciduous; b. - bark). - Tab. 4. Shrnutí antrakologické a xylotomické analýzy (ch. - uhlik; w. - drevo; d. - opadavý; b. - küra). 


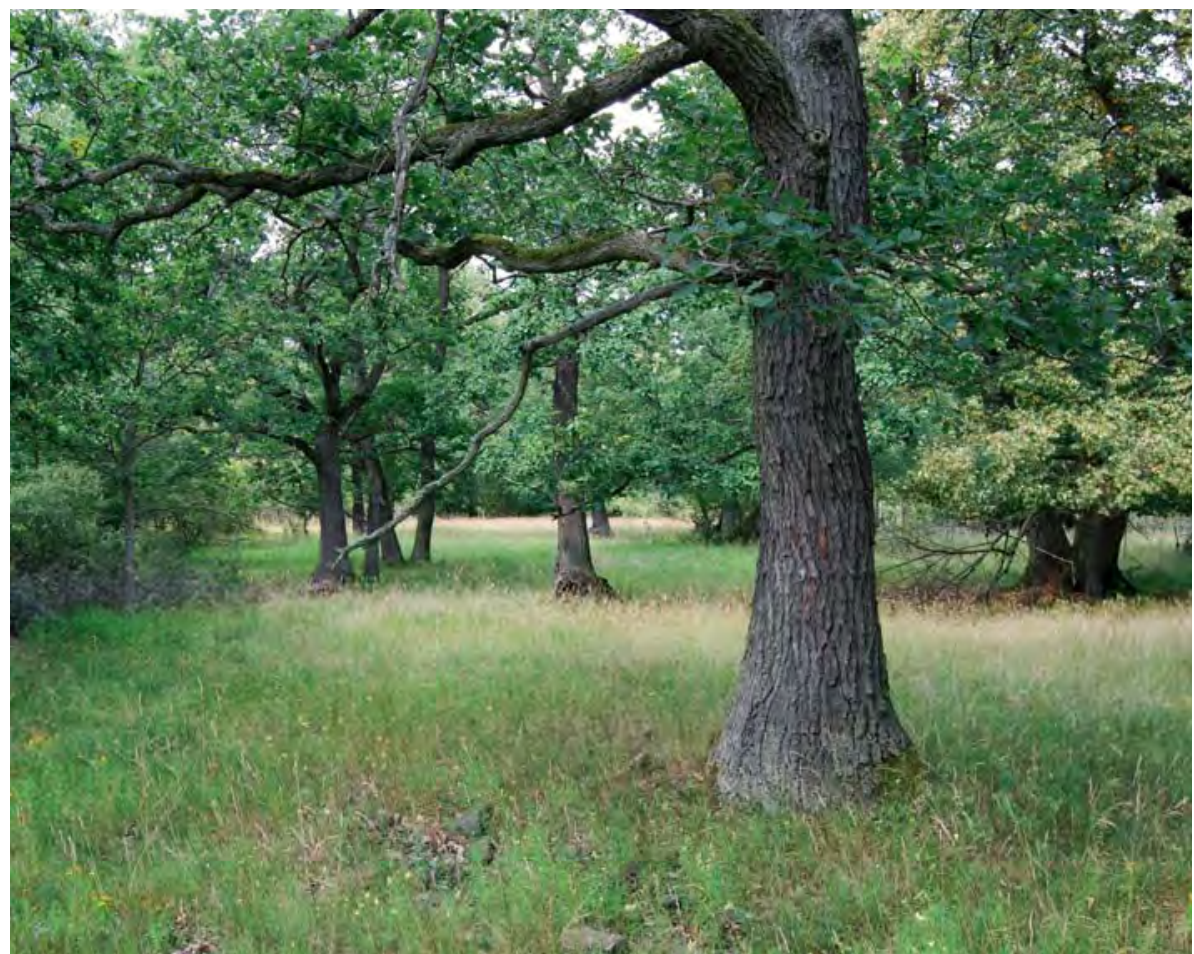

Fig. 26. Woodland pasturage on the hill Kružínský vrch near the town of Podborany (south-west Bohemia). The canopy layer almost does not rejuvenate because of intensive browsing. The herb layer comprises a wide spectrum of species (photo by P. Kočár). - Obr. 26. Lesní pastvina na kopci Kružínský vrch u města Podbořany (jihozápadní Čechy). Staré stromové patro téměr nezmlazuje $v$ důsledku intenzivní pastvy. $\checkmark$ podrostu lesa je druhovè bohaté bylinné patro (foto P. Kočár).

where the published assemblages with frequencies above 100 determinations originate, for example Kouty u Kravař (Opravil 1965), Sloup cave (Hadač - Hašek 1949) and of course the wood from Mohelnice (Opravil $1972 ; 1979 a ; 1979 b)$. Unfortunately, neither of these findings has been independently radiocarbon-dated. The assemblage of Carpinus macro-residues we found is the first undisputed evidence of this species in eastern Central Europe. Likewise, Fagus has rarely been identified in the pollen record of the northern Pannonian Basin from the LBK period (Petr et al. 2013; Šolcová et al. 2018). Its expansion and vegetation dominance at higher elevations, together with fir (Abies), have been dated to around 2000 BC (Jamrichová et al. 2017; Dudová et al. 2018).

The assemblage of 809 non-carbonized wood fragments, weighing $64.4 \mathrm{~g}$, was mainly composed of $\mathrm{Buer}$ cus wood fragments (Fig. 24), probably the remnants of selected constructional wood. A similar example is known from the Neolithic water well at Velim, where the assemblage of non-carbonized wood prevailingly contained Tilia wood because this well was reinforced with a hollow lime tree stem (Rybníček et al. 2018, 100). Other wood taxa that were identified in the form of noncarbonized wood might have originated from successive stands. The growth of hygrophilous vegetation in the neighbourhood of the well might be indicated by the presence of non-carbonized Alnus and Salix wood. Alternatively, the area of the settlement may have been overgrown with woody vegetation, including the nitrophilous Tilia and light-demanding Corylus (Fig. 25). Further from the settlement, we can assume the existence of sparse woodland or forest-steppe vegetation influenced mainly by grazing. On the tree floor we assume mainly solitary Quercus trees and under them Corylus shrubs and undergrowth with a dominance of grasses (Fig. 26).

\subsection{Plant macroremains and mosses}

Out of the 20 samples from the well's infill, a total of 46,486 plant macroremains were obtained from a $0.25-\mathrm{mm}$ sieve and a total of 115 plant macroremains were recovered from a $2-\mathrm{mm}$ sieve. All came from the full length of the well shaft, which is from depths between 120 and $325 \mathrm{~cm}$, and fewer than $1.5 \%$ of macroremains were charred (Tab. 5). The only comparable research in Czechia that has been published was conducted at Mohelnice (Opravil 1979a; 1979b), where the infill has been examined in a smaller volume and was, therefore, poorer in species. Quantitatively, only assemblages from Velim (Chlup et al. in preparation) and Ostrov (Sedláček et al. 2019; Kočár - unpublished data) are comparable.

Cultivated plants account for only $3 \%$ of the macroremains, but almost all were burnt (91\%). Einkorn wheat (Triticum monococcum) and emmer wheat (Triticum dicoccum) predominated. For Triticum monococcum, the ratio of spikelet forks to corns was 4.6:1 and for Triticum dicoccum the ratio of glumes to corns was $4.3: 1$ (Hillman 1981). Other crops present were fine-grained tetraploid wheat (Triticum durum/turgidum), so-called 'new weed wheat', and oilseeds such as poppy (Papaver somniferum/setigerum; Fig. 27: A) and flax (Linum usitatissimum; Fig. 27: B). The gathered fruits represent the remains of hazelnut fruits (Corylus avellana), strawberries (Fragaria cf. vesca), apple tree seeds (Malus sylvestris) and bladder cherries (Physalis alkekengi).

A total of $92 \%$ of the assemblage came from synanthropic plant species, especially Chenopodium spp. and Urtica dioica (Fig. 27: C). Anthriscus caucalis, Agrostemma githago (Fig. 27: D), Arctium sp., Descurainia sophia, Fallopia convolvulus, Hyoscyamus niger (Fig. 27: E), Nepeta 
Fig. 27. Cultivated plants: $\boldsymbol{A}$ - Papaver somniferum; $\boldsymbol{B}$ - Linum usitatissimum. Wild plant species: $\boldsymbol{C}$ - Urtica kioviensis; $\boldsymbol{D}$ - Agrostemma githago; $\boldsymbol{E}$ - Hyoscyamus niger; $\boldsymbol{F}$ - Onopordum acanthium (photo by P. Kočár, J. Šteld and Z. Vaněček). - Obr. 27. Kultivované rostliny: $\boldsymbol{A}$ - Papaver somniferum; $\boldsymbol{B}$ - Linum usitatissimum. Divoké druhy rostlin: $\boldsymbol{C}$ - Urtica kioviensis; $\boldsymbol{D}$-Agrostemma githago; $\boldsymbol{E}$ - Hyoscyamus niger; $\boldsymbol{F}$ - Onopordum acanthium (foto P. Kočár, J. Šteld and Z. Vaněček).
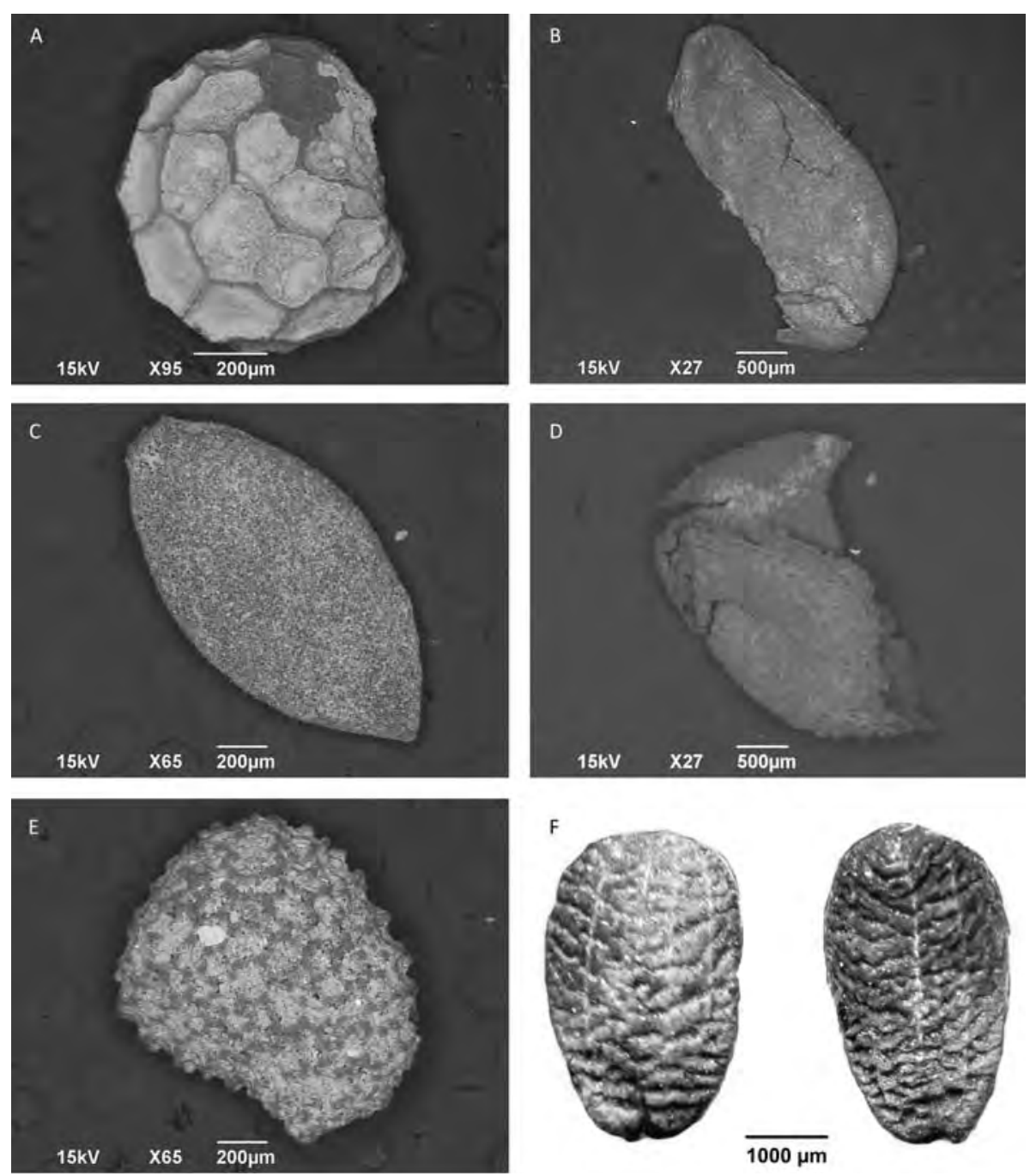

cataria, Onopordum acanthium (Fig. 27: F), Plantago major and Polygonum aviculare agg. were similarly common but significantly less numerous. Wetland species such as Batrachium sp., Iris pseudacorus, Lycopus europaeus, Potamogeton sp. or Ranunculus sceleratus and species of other (semi-)natural habitats (e.g. Carpinus betulus) occurred in smaller numbers.

Organic- and mineral-rich substrates were indicated by annual and biennial species of rich ruderal vegetation such as Hyosciamus niger, Urtica dioica, Onopordum acanthium, Carduus cf. crispus, Arctium sp. Rarely present were other ruderal species, for example Anthriscus caucalis, Lamium album/maculatum, Lamium purpureum, Linaria vulgaris, Nepeta cataria, Silene alba/dioica, cf. Capsella bursa-pastoris, Descurainia sophia, Echinochloa/ Setaria, Galeopsis bifida/tetrahit and cf. Verbascum sp.

Another ecological group were species of dry open habitats, which are otherwise recorded very rarely in LBK archaeobotanical material from Czechia. It includes species of dry grasslands, such as Cerastium fontanum, Fragaria vesca, Hypericum perforatum, Origanum vulgare and Vicia sepium, or ruderal and pasture communities, for example Agrimonia eupathoria, cf. Achillea sp., Potentilla cf. erecta, Rumex obtusifolius and Taraxacum sp. Wetter grasslands are indicated by species such as Carex cf. contigua, Cirsium oleraceum, cf. Juncus sp., Lychnis flos-cuculi, Scirpus sylvaticus and Ranunculus cf. repens.

The broad ecological group of field weeds and species of ruderal communities is represented Bromus arvensis, Fallopia convolvulus, Galium spurium, Setaria sp. and Setaria cf. verticillata.

The assemblage of plant macroremains obtained during this research is extraordinary among Neolithic structures unearthed in Czechia. This is thanks to the permanently humid environment inside the well, which, together with a lack of oxygen, allowed the preservation of a huge amount of unburnt plant macroremains. Thanks to this, the assemblage constitutes the oldest evidence of many species found in Czechia. Hyoscyamus niger has been known from the LBK settlement at Těšetice-Kyjovice (Vostrovská et al. 2019), so the find presented here is the second oldest made in Czechia. The find of Agrostemma githago is one of the first documenting the occurrence of this specialized weed of winter cereals during the Neolithic period. The oldest evidence has been dated to the Eneolithic (Kočár - Pokorná - Sádlo 2018; Pokorná et al. 2018). Next is Onopordum acanthium, known from the Early Iron Age, accompanied by Linaria vulgaris, Anthriscus caucalis and Nepeta 


\begin{tabular}{|c|c|c|c|c|c|}
\hline & \multirow[b]{2}{*}{ Species } & \multicolumn{2}{|c|}{ Uncharred } & \multicolumn{2}{|c|}{ Charred } \\
\hline & & $\bar{\Sigma}$ & 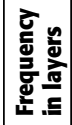 & $\bar{\Sigma}$ & 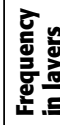 \\
\hline \multirow{6}{*}{$\begin{array}{l}\text { Cereal } \\
\text { grains }\end{array}$} & Triticum dicoccum & & & 21 & 8 \\
\hline & Triticum cf. dicoccum & & & 6 & 3 \\
\hline & Triticum monococcum & & & 18 & 8 \\
\hline & Triticum cf. monococcum & & & 2 & 2 \\
\hline & Triticum sp. & & & 4 & 3 \\
\hline & Cerealia & & & 195 & 13 \\
\hline \multirow{13}{*}{$\begin{array}{l}\text { Cereal } \\
\text { chaff }\end{array}$} & $\begin{array}{l}\text { Triticum aestivum/durum/ } \\
\text { turgidum (ri) }\end{array}$ & & & 4 & 2 \\
\hline & Triticum dicoccum $(\mathrm{gb})$ & 277 & 8 & 108 & 10 \\
\hline & Triticum cf. dicoccum (gb) & & & 1 & 1 \\
\hline & Triticum dicoccum/spelta $(\mathrm{gb})$ & & & 4 & 1 \\
\hline & Triticum monococcum/dicoccon (gb) & & & 8 & 1 \\
\hline & Triticum monococcum $(\mathrm{gb})$ & 232 & 9 & 237 & 12 \\
\hline & Triticum durum/turgidum (ri) & & & 3 & 2 \\
\hline & Triticum cf. durum/turgidum (ri) & & & 2 & 1 \\
\hline & Triticum cf. sp. "new-type" (gb) & 2 & 1 & 11 & 2 \\
\hline & Triticum sp. (gb) & 212 & 8 & 91 & 9 \\
\hline & Triticum sp. (ri) & 9 & 3 & 13 & 5 \\
\hline & Cerealia (straw internodium) & & & 7 & 4 \\
\hline & Cerealia (ri) & & & 3 & 1 \\
\hline \multirow{2}{*}{$\begin{array}{l}\text { Oil and } \\
\text { fibre plants }\end{array}$} & Linum usitatissimum & 2 & 1 & & \\
\hline & Papaver somniferum & 3 & 2 & & \\
\hline \multirow{9}{*}{$\begin{array}{l}\text { Wild plants } \\
\text { with edible } \\
\text { fruits or } \\
\text { nuts }\end{array}$} & Corylus avellana & 4 & 4 & & \\
\hline & Fragaria sp. & 19 & 6 & & \\
\hline & Fragaria vesca & 58 & 6 & & \\
\hline & Fragaria viridis & 9 & 2 & & \\
\hline & Malus/Pyrus & 3 & 1 & & \\
\hline & Malus sylvestris & 2 & 2 & & \\
\hline & Physalis alkekengi & 75 & 11 & & \\
\hline & Rubus idaeus & 1 & 1 & & \\
\hline & Sambucus sp. & 8 & 6 & & \\
\hline \multirow{26}{*}{ Wetlands } & Alisma sp. & 6 & 3 & & \\
\hline & Barbarea vulgaris & 1 & 1 & & \\
\hline & Batrachium sp. & 12 & 9 & & \\
\hline & Carex cf. acutiformis & 2 & 1 & & \\
\hline & Carex hirta & 1 & 1 & & \\
\hline & Cyperus fuscus & 1 & 1 & & \\
\hline & Eleocharis sp. & 3 & 1 & & \\
\hline & Chara sp. & 4 & 2 & & \\
\hline & Iris cf. pseudacorus & 3 & 2 & & \\
\hline & Lycopus europaeus & 151 & 7 & & \\
\hline & Mentha cf. aquatica & 3 & 2 & & \\
\hline & Mentha cf. arvensis & 1 & 1 & & \\
\hline & Myosoton aquaticum & 537 & 9 & & \\
\hline & Nitella sp. & 1 & 1 & & \\
\hline & Persicaria lapathifolia agg. & 141 & 9 & & \\
\hline & Peucedanum palustre & 1 & 1 & & \\
\hline & Potamogeton sp. & 4 & 1 & & \\
\hline & Potentilla supina & 8 & 2 & & \\
\hline & Ranunculus sceleratus & 21 & 7 & & \\
\hline & Rorippa palustris & 2 & 2 & & \\
\hline & Rumex cf. maritimus & 4 & 2 & & \\
\hline & Rumex obtusifolius s.l. & 10 & 3 & & \\
\hline & Rumex crispus/obtusifolius & 10 & 4 & & \\
\hline & cf. Scirpus sp. & 3 & 1 & & \\
\hline & Scutellaria galericulata & 6 & 4 & & \\
\hline & Urtica kioviensis & 10 & 3 & & \\
\hline
\end{tabular}

\begin{tabular}{|c|c|c|c|c|c|}
\hline & \multirow[b]{2}{*}{ Species } & \multicolumn{2}{|c|}{ Uncharred } & \multicolumn{2}{|c|}{ Charred } \\
\hline & & $\overline{\mathbf{z}}$ & 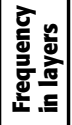 & $\bar{\Sigma}$ & 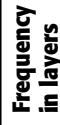 \\
\hline \multirow{18}{*}{ Grassland } & Agrimonia eupathoria & 1 & 1 & & \\
\hline & Arenaria serpyllifolia aggr. & 19 & 6 & & \\
\hline & Carex cf. contigua & 1 & 1 & & \\
\hline & Carex leporina & 2 & 1 & & \\
\hline & Carex muricata & 3 & 1 & & \\
\hline & Cerastium fontanum & & & 1 & 1 \\
\hline & Cirsium oleraceum & 2 & 1 & & \\
\hline & Hypericum perforatum & 49 & 11 & & \\
\hline & Juncus sp. & 2 & 1 & & \\
\hline & Lychnis flos-cuculi & 10 & 4 & & \\
\hline & Origanum vulgare & 21 & 7 & & \\
\hline & Plantago major & 37 & 6 & & \\
\hline & Polygonum aviculare agg. & 131 & 9 & & \\
\hline & Potentilla cf. erecta & 1 & 1 & & \\
\hline & Scirpus sylvaticus & 4 & 2 & & \\
\hline & Taraxacum sp. & 10 & 4 & & \\
\hline & Verbascum cf. thapsus & 1 & 1 & & \\
\hline & Vicia sepium & 1 & 1 & & \\
\hline \multirow{8}{*}{ Woodland } & Alnus sp. & 3 & 3 & & \\
\hline & Betula pendula & 3 & 3 & & \\
\hline & Carpinus betulus & 6 & 5 & & \\
\hline & Lamium galeobdolon s.l. & 4 & 1 & & \\
\hline & Quercus sp. & 32 & 9 & & \\
\hline & cf. Salix sp. & 3 & 1 & & \\
\hline & Tilia platiphyllos & 1 & 1 & & \\
\hline & Viola cf. riviniana & 1 & 1 & & \\
\hline \multirow{13}{*}{ Ruderal } & Chenopodium album/murale & 5007 & 9 & & \\
\hline & Arctium lappa & 108 & 9 & & \\
\hline & Carduus cf. crispus & 11 & 2 & & \\
\hline & Carduus nutans & 30 & 5 & & \\
\hline & Cirsium vulgare & 7 & 2 & & \\
\hline & Hyoscyamus niger & 33 & 10 & & \\
\hline & Lamium album & 4 & 1 & & \\
\hline & Lamium album/maculatum & 33 & 3 & & \\
\hline & Linaria vulgaris & 4 & 2 & & \\
\hline & Nepeta cataria & 55 & 9 & & \\
\hline & Onopordum acanthium & 72 & 10 & & \\
\hline & Torilis japonica & 44 & 8 & & \\
\hline & Urtica dioica & 4618 & 13 & & \\
\hline \multirow{10}{*}{$\begin{array}{l}\text { Ruderal } \\
\text { and weeds }\end{array}$} & Chenopodium album & 27025 & 14 & & \\
\hline & Chenopodium sp. & 4799 & 12 & & \\
\hline & Atriplex sp. & 1082 & 8 & & \\
\hline & Brassica nigra & 2 & 1 & & \\
\hline & Cirsium arvense & 35 & 3 & & \\
\hline & Descurainia sophia & 217 & 9 & & \\
\hline & Digitaria sanguinalis & & & 5 & 1 \\
\hline & Echinochloa/Setaria & & & 1 & 1 \\
\hline & Galeopsis bifida/tetrahit & 30 & 7 & & \\
\hline & Verbascum sp. & 4 & 3 & & \\
\hline \multirow{8}{*}{ Weeds } & Chenopodium polyspermum & 246 & 4 & & \\
\hline & Lamium purpureum & 20 & 5 & & \\
\hline & Setaria verticillata/viridis & 46 & 5 & 3 & 2 \\
\hline & Agrostemma githago & 1 & 1 & & \\
\hline & Bromus arvensis & & & 10 & 4 \\
\hline & Fallopia convolvulus & 63 & 8 & & \\
\hline & Galium spurium & 1 & 1 & & \\
\hline & Scleranthus annuus s.str. & 2 & 2 & & \\
\hline
\end{tabular}




\begin{tabular}{|c|c|c|c|c|c|}
\hline & \multirow[b]{2}{*}{ Species } & \multicolumn{2}{|c|}{ Uncharred } & \multicolumn{2}{|c|}{ Charred } \\
\hline & & $\bar{z}$ & 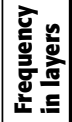 & $\bar{\Sigma}$ & 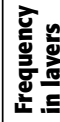 \\
\hline \multirow{15}{*}{$\begin{array}{l}\text { Unknow } \\
\text { or various } \\
\text { habitats }\end{array}$} & Achillea sp. & 1 & 1 & & \\
\hline & Aphanes sp. & 1 & 1 & & \\
\hline & Betula sp. & 2 & 1 & & \\
\hline & Brassica/Sinapis & 1 & 1 & & \\
\hline & Bromus sp. & 16 & 5 & 17 & 8 \\
\hline & cf. Bromus sp. & 2 & 1 & & \\
\hline & Carex flacca/flava & 2 & 2 & & \\
\hline & Carex sp. (2D) - bicarpelate & 1 & 1 & & \\
\hline & Carex sp. (3D) - tricarpelate & 5 & 4 & & \\
\hline & Cirsium/Carduus & 101 & 9 & & \\
\hline & Cuscuta sp. & 20 & 3 & & \\
\hline & Cyperus sp. & 10 & 1 & & \\
\hline & Fragaria/Potentilla & 4 & 2 & & \\
\hline & Galium sp. & 1 & 1 & & \\
\hline & Lamium sp. & 63 & 8 & & \\
\hline
\end{tabular}

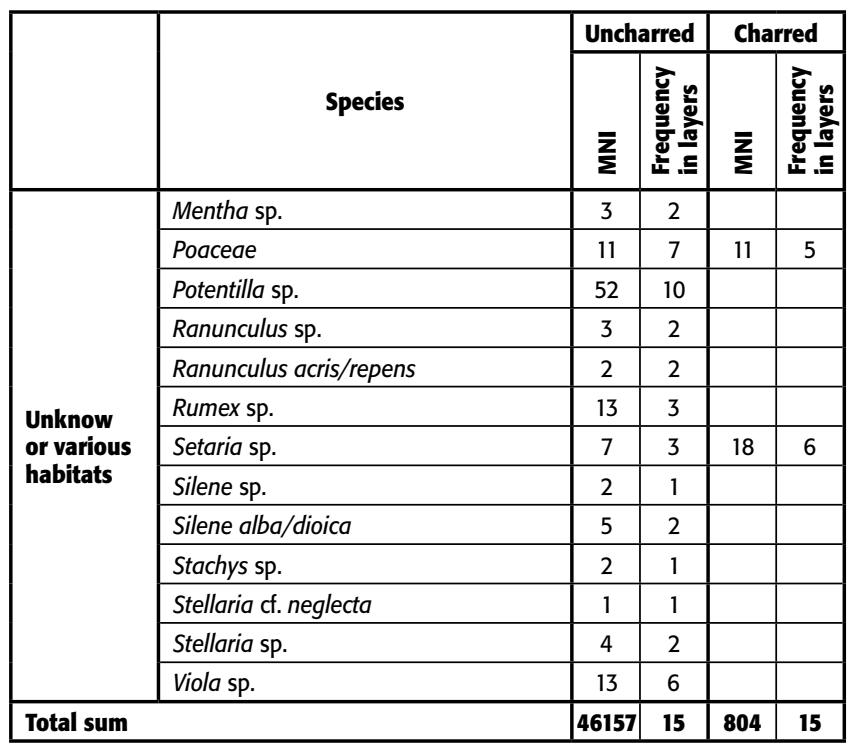

Tab. 5. Results of macroremains analysis (MNI - minimal number of individuals; ri - rachis internode; gb - glume base). - Tab. 5. Výsledky makrozbytkové analýzy (MNI - minimální počet jedinců; ri - článek vřetene klasu; gb - báze plevy).

cataria, which have so far been known only from the Early Medieval period (Pokorná et al. 2018). Finally, Physalis alkekengi has previously been documented to occur only in the High Medieval period (Opravil 1996) and was also found in a Renaissance context (Kočár et al. 2007).

Remains of mosses were present almost throughout the vertical section of the well's infill. The thickness of the analysed vertical section of the well was $205 \mathrm{~cm}$. This section was situated between actual depths of 120$325 \mathrm{~cm}$ below the hidden subsoil level. The moss remains were surprisingly well preserved, so they could mostly be determined down to the level of species. In 26 samples from the vertical section of the well, we identified 21 taxa of mosses in total (Tab. 6). Most taxa (14) were found at depths between 280 and $300 \mathrm{~cm}$ in the vertical section of the well.
The whole section of the well was dominated by the wetland Knieff's hook-moss (Drepanocladus aduncus; Fig. 28: A), which is still abundant in lowland habitats with stagnant water. The remaining species were present in much lower quantity. The species detected were probably naturally growing in the well or fell into it from trees or buildings in the neighbourhood. The well was most probably open, which was indicated by the presence of phototrophic mosses.

The mosses found in the sediments belong to three ecological groups: (i) wetland mosses - Drepanocladus aduncus, Hygroamblystegium varium, Leptodictyum riparium, Palustriella commutata and Hygrohypnum sp., (ii) epiphytic mosses - Alleniella complanata, Amblystegium serpens, Anomodon longifolius, Anomodon viticulosus (Fig. 28: B), Hypnum cupressiforme, Leucodon sciuroides, Neckera pennata, Orthotrichum sp., Sciuro-
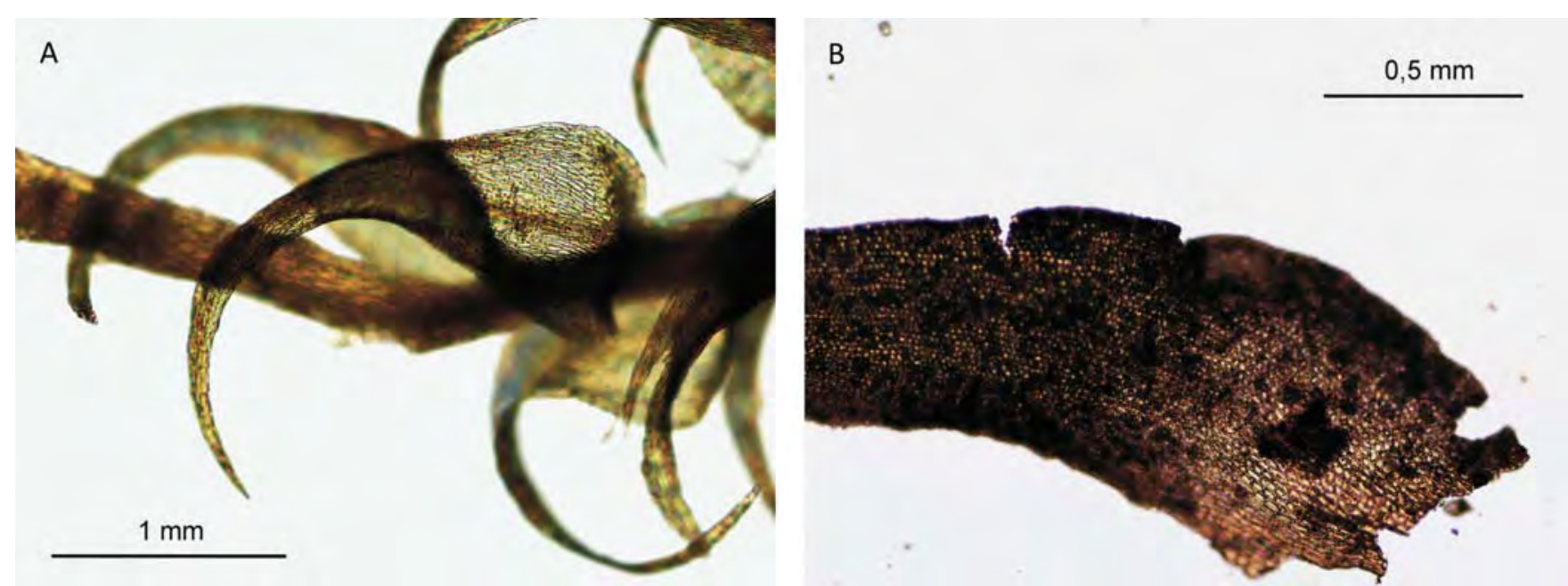

Fig. 28. $\boldsymbol{A}$ - Drepanocladus aduncus; B - remains of a moss leaf of Anomodon viticulosus (photo by Z. Hradilek). - obr. 28. $\boldsymbol{A}$ - Drepanocladus aduncus; $\boldsymbol{B}$ - zbytky listu mechu Anomodon viticulosus (foto Z. Hradílek). 


\begin{tabular}{|c|c|c|c|c|c|c|c|c|c|c|c|c|c|c|c|c|c|c|c|c|c|}
\hline 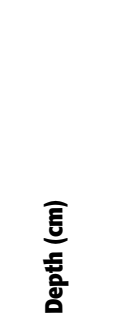 & 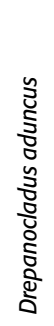 & 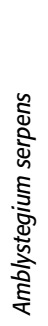 & 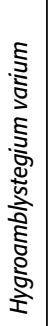 & 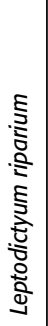 & 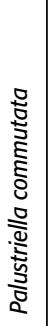 & 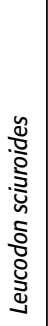 & 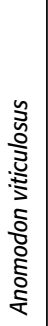 & 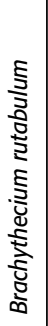 & 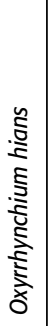 & 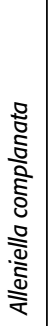 & 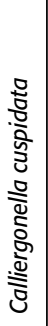 & 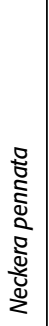 & 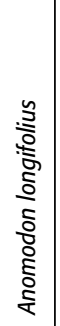 & 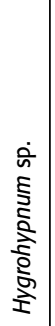 & 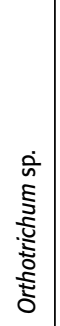 & 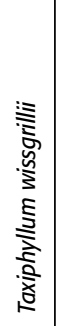 & 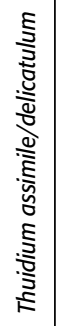 & 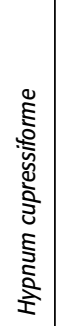 & 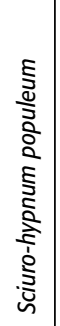 & 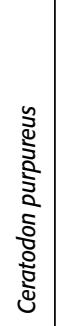 & 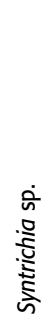 \\
\hline $120-130$ & & 2 & & + & & & & 92 & 5 & & & & & & & & & & & & \\
\hline $130-140$ & + & + & & & & & & 70 & 1 & & & & & & & & & 29 & & & + \\
\hline $140-150$ & 99 & 1 & & & & & & & & & & & & & & & & & & & \\
\hline $150-160$ & 100 & & & & & & & & & & & & & & & & & & & & \\
\hline $160-170$ & & & & & & & & + & & & & & & & & & & & & + & \\
\hline $170-180$ & 62 & 17 & 3 & & + & & & 7 & 7 & & & & & & & & & & 4 & & \\
\hline 180-190 & 83 & 10 & 7 & & + & & & & & & & & & & & & & & & & \\
\hline $190-200$ & 85 & 7 & 8 & & + & & & & & & & & & & & & & & & & \\
\hline $200-210$ & 67 & 25 & 8 & & + & & & & & & & & & & & & & & & & \\
\hline $210-220$ & 65 & 31 & 4 & & + & & & & & & & & & & & & & & & & \\
\hline $220-230$ & 65 & 29 & 6 & & + & & & & & & & & & & & & & & & & \\
\hline $230-240$ & 70 & 28 & 2 & & & & & & & & & & & & & & & & & & \\
\hline $240-250$ & 80 & 10 & 1 & & & & & & & & & & & & & & & & & & \\
\hline $250-260$ & 95 & 4 & 1 & + & & & & & & & & & & & & & & & & & \\
\hline $260-270$ & 98 & 2 & + & + & & & & & & & & & & & & & & & & & \\
\hline $270-280$ & 90 & 4 & 1 & + & & 1 & + & & & 2 & 1 & 1 & & + & & + & + & & & & \\
\hline $280-290$ & 91 & 3 & 1 & + & & 1 & + & & & 2 & 1 & 1 & & + & & + & + & & & & \\
\hline $290-300$ & 92 & 3 & 1 & + & & 1 & 1 & & & + & 1 & + & + & + & + & + & + & & & & \\
\hline $300-310$ & 95 & + & & & & 1 & 1 & & & & & & + & & + & & & & & & \\
\hline $310-325$ & 97 & + & & & & 1 & 1 & & & & & & + & & + & & & & & & \\
\hline Total sum & 18 & 18 & 13 & 6 & 6 & 5 & 5 & 4 & 3 & 3 & 3 & 3 & 3 & 3 & 3 & 3 & 3 & 1 & 1 & 1 & 1 \\
\hline
\end{tabular}

Tab. 6. Estimates of the relative proportions of moss species in layers of the vertical section (cross indicates the quantity below 1\%). Tab. 6. Odhady relativnich podilù druhů mechu ve vrstvách profilu (krížek znamená množství pod $1 \%$ ). hypnum populeum and Syntrichia sp., and (iii) terrestrial mosses - Brachythecium rutabulum and Oxyrrhynchium hians. The moss Neckera pennata today represents a rare epiphytic species growing in our best-preserved forests. Most mosses in the well (86\%) are perennial or multi-annual species.

In the vertical section of the well's infill, we can discern three more or less distinct layers with slightly different spectra of species: (i) $120-140 \mathrm{~cm}$ of the well's infill - the layer mostly contains remains of terrestrial mosses, which are still to this day abundant in surrounding forests; (ii) $150-250 \mathrm{~cm}$ - the wetland moss Drepanocladus aduncus begins to dominate together with other hygrophilous species like Hygroamblystegium varium and Palustriella commutata, and some layers contain isolated remains of terrestrial mosses Amblystegium serpens, Brachythecium rutabulum, Oxyrrhynchium hians; and (iii) $260-325 \mathrm{~cm}$ - besides the ever-present hygrophilous species, we can also identify some sporadic, but not isolated, remains of mosses that can be classified as facultative epiphytes Alleniella complanata, Amblystegium serpens, Anomodon longifolius, A. viticulosus, Leucodon sciuroides and Neckera pennata, Orthotrichum sp.

\subsection{Zoology}

The assemblage contained around 1,171 finds. At least 29 individuals of 16 animal species were identified in this assemblage ( $\mathrm{Tab} .7)$. Remains of various vertebrate groups were recorded, namely fish, amphibians, reptiles, birds and mammals, but most of the finds were of mammalian origin. No malacofauna has been preserved because of the too acidic environment at the site. The remains of small vertebrates made up a mostly autochthonic assemblage of wild animals that probably died at the site.

Fish were represented by a single find of a scale. Remains of amphibians, namely frogs and toads, were more common (Bufo viridis, Bufo sp., Rana arvalis, Rana sp., Anura). Herpetofauna was supplemented with Lacerta sp. Undetermined birds and small species of songbirds (Passeriformes) were found at the site.

Three groups of mammals were documented: insectivores, rodents and carnivores. From the first group, remains of shrews and white-toothed shrews were discovered: Crocidura suaveolens, Crocidura sp., Sorex cf. araneus, Sorex cf. minutus and Soricidae. Only one species of carnivore was detected, the common weasel (Mustela nivalis).

Abundant remains of rodents were discovered in the well's infill. Finds of the European hamster (Cricetus cricetus) were the most numerous. Four species of voles were recorded in the assemblage: Arvicola terrestris, Clethrionomys glareolus, Microtus arvalis and Microtus oeconomus, which is a species of damp tundra habitats. The find of this vole at the Uničov site is one of the youngest from Czechia because it disappeared during the Neolithic period (Horáček-Ložek 1988). Other finds were determined as Microtus sp. Mice were also present, 


\begin{tabular}{|l|l|c|c|}
\hline \multicolumn{1}{|c|}{ Species } & \multicolumn{1}{c|}{ Taxon } & n & MNI \\
\hline Pisces indet. & undet. fish & 1 & 1 \\
\hline Anura & frogs and toads & 10 & \\
\hline Bufo sp. & toad & 2 & \\
\hline Bufo viridis & European green toad & 1 & 1 \\
\hline Rana sp. & frog & 1 & \\
\hline Rana arvalis & moor frog & 5 & 1 \\
\hline Lacerta sp. & lizard & 3 & 1 \\
\hline Aves indet. & undet. birds & 3 & 1 \\
\hline Passeriformes & singing birds & 2 & 1 \\
\hline Mammalia indet. & undet. mammals & 507 & \\
\hline Soricidae & shrews & 5 & \\
\hline Crocidura sp. & white-toothed shrew & 1 & \\
\hline Crocidura suaveolens & lesser w.-t. shrew & 4 & 2 \\
\hline Sorex cf. araneus & common shrew & 5 & 2 \\
\hline Sorex cf. minutus & Eurasian pygmy shrew & 1 & 1 \\
\hline Rodentia & rodents & 556 & \\
\hline Cricetus cricetus & European hamster & 23 & 5 \\
\hline Arvicola terrestris & European water vole & 7 & 2 \\
\hline Microtus sp. & vole & 12 & 1 \\
\hline Microtus arvalis & common vole & 7 & 3 \\
\hline Microtus oeconomus & tundra vole & 1 & 1 \\
\hline Clethrionomys glareolus & bank vole & 1 & 1 \\
\hline Muridae & mice & 1 & \\
\hline Apodemus flavicollis/sylvaticus & wood mouse & 3 & 1 \\
\hline Mus musculus & house mouse & $3+1$ cf. & 2 \\
\hline Micromys minutus & Eurasian harvest mouse & 2 & 1 \\
\hline Mustela nivalis & least weasel & 3 & 1 \\
\hline Total sum & & $\mathbf{1 1 7 1}$ & $\mathbf{2 9}$ \\
\hline
\end{tabular}

Tab. 7. Summary of small vertebrate finds ( $n$ - number of finds; $M N I-m i-$ nimum number of individuals). - Tab. 7. Shrnutí nálezů malých obratlovců ( $n$ - počet nálezư; MNI - minimální počet jedinců).

namely Apodemus flavicollis/sylvaticus, Micromys minutus, Mus musculus and Muridae. Further 556 fragments were classified as rodents and 507 fragments as undetermined mammals.

Looking closer at the depth of the finds, between 150 and $160 \mathrm{~cm}$ only the fish scale was recorded. In the lower part (180-230 cm) of the remaining vertical section, finds of Bufo, Crocidura, Sorex cf. araneus, Crice- tus, Arvicola, Clethrionomys, Microtus arvalis, Microtus oeconomus, Apodemus, and Mus were discovered. The middle part $(230-280 \mathrm{~cm})$ contained the remains of Bufo, Lacerta, an unknown songbird, Sorex cf. araneus, Sorex cf. minutus, Cricetus, Arvicola, Microtus, Apodemus, Micromys, Mus and Mustela. The bottom part $(280-325 \mathrm{~cm})$ was poorer in finds, Rana, birds, Cricetus, Microtus arvalis, Apodemus and Mus being found.

Regarding the taphonomy of the assemblage, no finds with cutting or gnawing marks were recorded whereas signs of burning appeared in six cases. Two fragments were partially burnt black, one fragment was burnt black, one fragment was burnt black to white, and two fragments were burnt white.

\subsection{Entomology}

The acquired material included 671 fragments of 422 insect individuals (MNI). The largest group was represented by 380 individuals (at least 220 species and genera) of well-sclerotized beetles (Coleoptera; Fig. 29). Other recorded taxa were Hymenoptera (especially Formicidae), Heteroptera and Auchenorrhyncha. The analysed samples also included six specimens of mites (Acari, mainly Oribatida). These are preliminary results and a separate article will be devoted to the overall evaluation.

The identified insect species at the same time indicate the presence of a variegated mosaic of biotopes in the neighbourhood of the well. Distinctly represented were: (a) disturbed early succession biotopes, often xerothermic, (b) pastures, (c) grasslands, (d) forests and (e) various types of riparian biotopes. Based on our preliminary analysis, it can be stated that of the abovementioned groups of species, those of early-succession habitats of different natural abundance were the most significant. Widespread species of ruderal habitats and field edges were present in the material (Bembidion lampros and Chrysolina fastuosa), as were stenoid beetles of naturally rich xerothermic stands and steppes (Centricnemus leucogrammum and Pleurophorus sp.). A low frequency of woodland species (e.g. Molops piceus) and,
Fig. 29. Number of individuals of beetles (Coleoptera) along the vertical section of the well. - Obr. 29. Počet jedinců brouků (Coleoptera) v profilu studny.

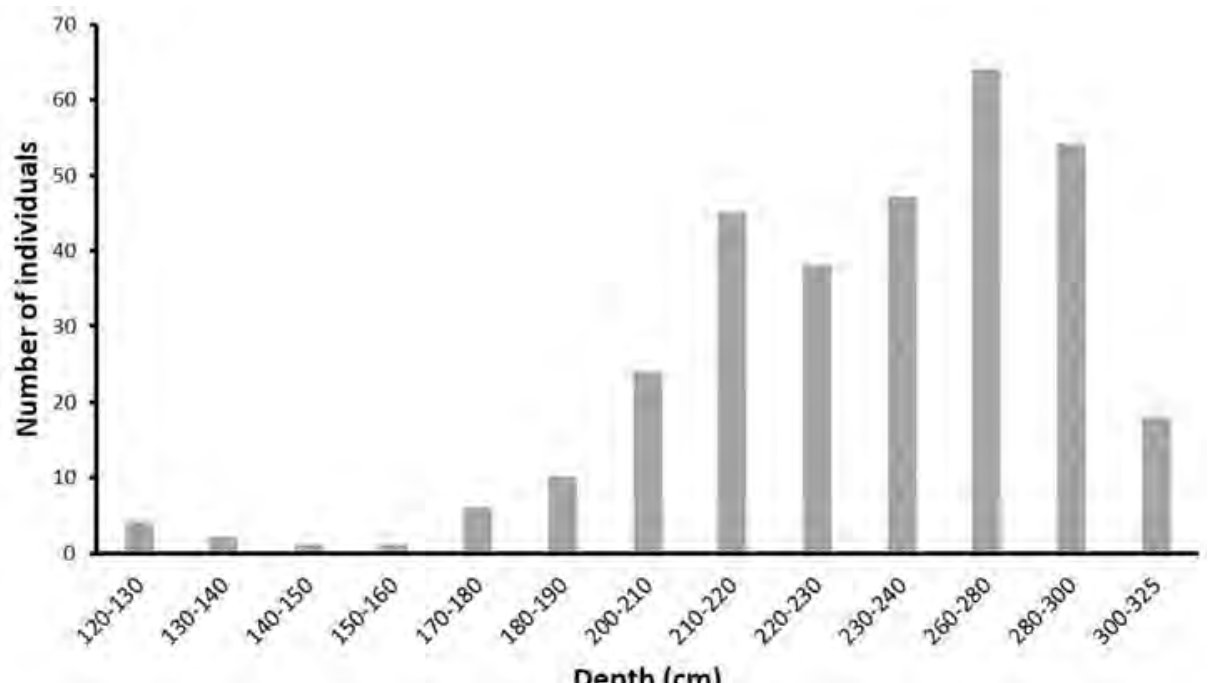

Depth $(\mathrm{cm})$ 
conversely, a greater abundance of pasture-bound coprophages (Onthophagus spp. and Aphodinae) then suggests the presence of a rather open grassland with woody vegetation (Hellquist 1999; Whitehouse - Smith 2010). Naturally rich river bank habitats, such as open sandy benches, were probably also represented in the surroundings, as evidenced, for example, by the occurrence of ripicel ground beetles of the genus Dyschirius.

In addition to the insect remains themselves, larval galleries of wood-boring insects, for example longhorned beetles (Cerambycidae) and ambrosia beetles (Xyloterus sp.), were documented on the timbers. These beetles can only live in dead wood and began their development before the wood was used for the construction.

Our preliminary analysis of the observed community of other insect groups, namely true bugs and ants, paints a similar picture as in the case of beetles. Despite the relatively small number of individuals, it can be said that there was a colourful mosaic of different habitats in a relatively small area around the well. This is evidenced by the presence of species of habitats such as open dry places (i.e. Microporus nigrita, Formica $\mathrm{cf}$. $\mathrm{cu}^{-}$ nicularia), sparse woodlands (Dolichoderus quadripunctatus), wastegrounds and woodland edges (Tritomegas bicolor), and wet habitats (Netioglossa pusila).

\section{Discussion}

\subsection{Construction and function of the wooden well}

The results pertaining to the absolute chronology of the wooden lining and the infill of the Uničov well can be evaluated as synchronous. It has been proved that both the construction and the subsequent usage of the well date back to the $51^{\text {st }}$ century $\mathrm{BC}$, that is, to the Middle LBK. If we compare the results of dendrochronological dating of recently excavated LBK wells in Czechia, the Uničov well from 5093-5085 BC is the youngest. Velim well is from the turn of 5196 and 5195 BC (Rybníček et al. 2018, 100-101) and the oldest is the Ostrov well from the turn of 5256 and 5255 BC (Rybníček et al. 2020). Other European LBK wells from which dendrodates have been obtained fall within a similar time interval. The youngest among them is the ErkelenzKückhoven well from 5091 BC, which is almost contemporary with the Uničov well. A few years older are the Eythra well no. 17 from 5098/5097 BC and the Schkeuditz-Altscherbitz well from 5099 BC. Three of the seven LBK wells from Droßdorf have also been dated dendrochronologically: well no. $3174=5134$ BC, well no. $3682=5145 \pm 10 \mathrm{BC}$ and well no. $3679=5198 \pm$ $10 \mathrm{BC}$. These wells are slightly older, just like the Brodau well from $5190 \pm 10 \mathrm{BC}$ and the two-phase Eythra well no. 21 from $5196 \pm 10 \mathrm{BC}$ with repairs from approximately $5127 \mathrm{BC}$. The Eythra well no. 22 is not older than $5193 \pm 10$ BC. Furthermore, the well at Leipzig-Plaußig provided very interesting dendrochronological data for the period of 5260-5080 BC, being the longest used LBK well with evidence of repairs or rebuilding activities (Tegel et al. 2012; Kretschmer et al. 2016; Friedrich 2017, 421-440).
Even though we apply state-of-the-art calibration tools, the probability interval for exact dating using the radiocarbon method logically remains much wider compared to dendrochronology. On the other hand, the radiocarbon method can be used for the absolute dating of wells with a low number of tree-rings or without a preserved wooden lining. Radiocarbon dates for the wooden lining and infill of the Uničov well fall within the wide interval of 5464-4615 cal. BC. The Ostrov well has a similar range (5341-4934 BC), but it ends 319 years earlier (Rybníček et al. 2020). The dating of the Mohelnice well, where one date of $5533 \pm 65$ cal. BC contradicts other dates of $5193 \pm 94$ cal. BC (Schmidt - Gruhle 2003, 56), $5174 \pm 104$ cal. BC and $5270 \pm 163$ cal. BC (Neustupny - Vesely 1977, 185), remains to be resolved. The material from the Velim well, whose interval is also much shorter 5216-4811 BC (Chlup et al. in preparation), proved to be more recent. The Asparn-Schletz well from 5312-4962 BC, without wooden lining, is essentially contemporary with the Uničov well (Windl 1998). Seven radiocarbon dates within the interval of 53004966 BC from the wells at Droßdorf (Kretschmer et al. 2016) also correspond to the Uničov and AsparnSchletz wells.

LBK settlements were mostly supplied with surface water from rivers and streams. The first farmers were familiar with the landscape and they probably had basic knowledge of hydrology (Pavlů - Zápotocká 2013, 56). The location for the water well and for the settlement in the vicinity of Uničov was chosen for several reasons. The builders of the well probably supposed that the groundwater level at this place would be easily accessible because of the nearby stream. The presence of groundwater was also indicated by vegetation. The palynological and anthracological spectra prove that the alluvium had already formed in the neighbourhood of the site. The Uničov well was situated in the immediate neighbourhood of two houses on the eastern edge of the settlement area. However, anchoring the well in the context of the site is difficult. According to radiocarbon dating, the well infilling is probably older than the excavated part of the settlement area (Vostrovská unpublished data). Thus, the chronological horizon from the settlement area is not comparable to that of a well. It seems that the well was coeval with an unexcavated part of the settlement areal alternatively, human activity from the time of the construction and utilization of the well is not archaeologically detectable.

Before the construction of the wooden lining of the well, a pit must have been dug out down to the sandygravelly water-bearing horizon. The well pit therefore must have reached the groundwater level (Weiner 1998, 200). The well was subsequently built in this construction pit. Baskets with spoil may have been pulled up with the help of a pulley and thick ropes. Digging tools such as hoes and spades as well as pulleys have been found at the Erkelenz-Kückhoven site (Weiner 1992a). The bottom of the well pit at Uničov was neither modified nor reinforced, because the sandy-gravelly subsoil did not demand such adjustments. On the other hand, rubble was stacked at the bottom of the Ostrov well (Kočár - personal communication) and the hollow trunk construction of well no. 3684 at Droßdorf was sup- 
ported by stones at the bottom (Kretschmer et al. 2016). The bottom of the well at Erkelenz-Kückhoven was covered with loose boards (Weiner 1994; 1997). Many tree branches were discovered at the bottom of well no. 2013 at Arnoldsweiler (Husmann - Cziesla 2014, 102-103).

Not only Neolithic wells (Tegel et al. 2012), but also Protohistoric wells (Pleinerová 2005; Sedláček et al. 2008) in Central Europe, were mostly built of oak wood. Selected oaks were felled with adzes and their trunks then had to be sawn into pieces and debarked. The cross-sections of building elements and the sequence of tree-rings prove that the oak trunks were split radially. This method may have produced at least 12 pieces of split wood from each log. The necessary amount of wood planks was then probably transported to the construction site (Weiner 1998, 208-209). Tool marks of polished axes and shoe-adzes, mostly made of metabasites, can be observed especially on the notches on each post and the tapered ends of the horizontal boards from the Uničov well (Rybníček et al. 2018, 101). The wooden lining of the well was intended to reinforce the walls of the well shaft and prevent them from collapsing, and to protect the wellspring from being polluted by external water. The internal construction of the Uničov well was composed of four corner posts with longitudinal grooves, in which horizontal boards were embedded. However, one post was found at the bottom of the shaft, on which leaned three boards, whose right end dropped out from the groove of the corner post. Lateral pressure of the water-bearing sediment disrupted the integrity of the wooden lining and the first farmers solved this problem by creating a post barrier. This constitutes direct evidence that the construction was repaired at a time when the well was in operation. Until now, it was assumed that the grooved construction was not used in the Neolithic period. Wells in the Neolithic period were usually tubelike or consisted of a chest-like log construction with split wooden planks (e.g. Tegel et al. 2012). Comparable grooved construction, except the last LBK well found at Ostrov (Rybníček et al. 2020), are only known from the Bronze Age, the Roman period and the Middle Ages, that is at least three thousand years later (Gollnisch-Moos 1999; Rageth 1986; Tegel et al. 2012).

The space between the wooden lining and the wall of the pit was usually very thoroughly filled with some additional material. The wooden lining of the Uničov well was daubed from the outside with an approximately $6 \mathrm{~cm}$ thick layer of grey clay. We suppose that it was a shield sealing of the well construction. Nowadays, clay is used to protect wellsprings from leaking contaminated external water. Moreover, the boards fitted very tightly into one another, so they did not require additional fixing. Similarly, the wall of the Velim well wooden lining was daubed (Chlup et al. in preparation). In logbuilt wells, on the other hand, the chinks between logs were filled with moss. This way of caulking has been documented in the wells from Erkelenz-Kückhoven, where an up to $2 \mathrm{~cm}$ thick layer of compressed felted moss was found at irregular intervals in spaces between timbers (Weiner 1992b, 32). Moss caulking is also known from Zipsendorf (Einicke 1998, 77), Eythra (Stäuble Campen 1998, 8), Altscherbitz (Elburg - Herold 2010, 24-27) and Leipzig-Plaußig (Rösch 2017, 404-405).
During the excavation of the well at Uničov, no postholes or other evidence of an aboveground construction were detected in the upper part of the well. Such finds are only known from the LBK well at Erkelenz-Kückhoven. Dressed round wood with incisions, discovered in the well shaft, was interpreted as a possible winch. The incisions on this round wood might have been imprinted by a rope, with the help of which vessels with water were pulled up from the well (Weiner 1995). The rhombic layout of the well shaft at Uničov was identified at a depth of $120 \mathrm{~cm}$ below the hidden surface. Our interpretation is that subsurface water was accessed through the mouth of a wide funnel-shaped pit. The lining itself most probably originally began at the abovementioned depth of $120 \mathrm{~cm}$. The well was apparently open during its operation period, which is also confirmed by the presence of aeolian dust sedimented inside. We can say with certainty that the mouth of the well was not completely covered with a lid, which is corroborated by the analysis of mosses and plant macroremains. The detected species are mostly light-demanding and they grew spontaneously in the well.

\subsection{Usage, infilling and decline of the well}

The accumulation of sediments inside the well was studied to explore the water management and usage of the well itself. Several layers were recognized in the infill, reflecting different sedimentary environments and modes of infilling. The results of micromorphological analysis and environmental analysis indicate which events took place inside the well. A number of different development facies were recognized there. Generally, there is a sandy construction infill (possibly associated with repair work) at the base followed by well-sorted silty sediment related to an influx of dust, probably of aeolian origin, possibly redeposited by water from surrounding sediments and homogenized by the daily pulling of water up from the well. Similarly, the presence of aeolian dust in the well has also been documented at the Roitzschjora site from the Eneolithic period, where it is associated with deposition in a water environment in an open structure (Tolksdorf et al. 2017). A similar type of infill has also been identified in the LBK well at the Brodau site, where evidence of sedimentation under calm conditions beneath the waterline has been documented (Tinapp - Schneider - Stäuble 2013, 543).

Based on the evidence of that the well was repaired, we suppose that the sandy sediment at the base does not reflect the real beginning of the use of the well. The repair was probably done to clear the well and remove the original infill, so the lowermost sediment at the base can be interpreted as sand redeposited from the surrounding subsoil during the repair. The infill from the base up to the depth of $300 \mathrm{~cm}$ did not contain many charcoal pieces, plant macroremains or insect remains, which testifies to the cleanness of the water during the usage of the well after the repair. In the following phase, the environment in the well at least once turned into a muddy environment penetrated by plant roots, which indicates that the underground water level had decreased. This is in accordance with the presence of wetland mosses and semiaquatic mosses tolerant a fluctu- 
ating water level. The recovery of the water level was followed by several phases of microlamination. They reflect a series of events that caused repeated influx of coarse silt into the well. The lamination might refer to different usage of the well in individual phases or to a possible influence of meteorological phenomena such as heavy rain. The presence of wetland plants also supports the idea of a fluctuating water level. Later in the sequence we can observe deposition of a similar sediment as that before desiccation, but the well was probably gradually polluted by organic material, as is evident from quantitative curves of charcoal, macroremains and entomological material. In this phase of the well infilling, we can also identify remnants of epiphytic mosses (depth 270-300 cm), which might have fallen into the open well from surrounding trees. A similar situation was detected with the wetland sediment at the Santovka site (Šolcová et al. 2018). The increased amount of organic material is connected with a shift to more eutrophic conditions. This variable stage was followed by a quick, possibly single-phase infilling with the upper soil horizon mixed with pellets of pale clay from the outer well sealing and with settlement waste $(130-225 \mathrm{~cm})$. This means that the well was probably backfilled intentionally and not by gradual silting or a spontaneous collapse of its structure, as has been suggested for the well at Roitzschjora (Tolksdorf et al. 2017). This idea is also supported by results of radiocarbon dating, which does not indicate gradual infilling, but rather deposition of mixed material of various ages. The usage, infilling and decline of the well took place in such a short time interval that radiocarbon data are not able to detect. The overall curve of calibrated radiocarbon dates for samples from the well infill has much greater dispersion than that for the wooden lining. This is caused by the presence of older and younger ages for various dated samples. It is clear that the age of the samples is not related to the depth from which they were taken. This supports the idea that most of well infill is composed of a mixture of various surface materials and that it was accumulated over a short period, maybe even in one event. Older ages possibly relate to older settlement waste that was accumulated near the well for a long time before its construction.

Material from the upper dark layer of the well infill (facies 8) contains coprophagous and saproxylic beetles, for example the wheat weevil (Sitophilus granarius), which are bound to decomposing plants and various agricultural material, so it can be said that the infill material partly consisted of organic waste. The bones of the house mouse (Mus musculus) were also found. It is which is a synanthropic species that spread with the first farmers. This is also evidenced by the quantity of plant macroremains and anthracomass between $180 \mathrm{~cm}$ and $280 \mathrm{~cm}$ of depth. This mixture of household waste is similar to the well infills from Erkelenz-Kückhoven and Brodau (Zerl - Herbig 2012). The uppermost part of the well infill under examination was affected by pedogenesis.

\subsection{Subsistence strategy of the first farmers}

The macroremains analysis performed yielded a high number of cultivated crops, weeds and fruits of shrubs, and pollen samples revealed a rich spectrum of herbs.
Because of the water-logged environment, $98.5 \%$ of the macroremains were uncharred, as in other Neolithic wells in Europe, for example that at Erkelenz-Kückhoven with 96.4\% (Zerl - Herbig 2012), that at Eythra with $98.8 \%$ or that at Brodau with $86.9 \%$ (Herbig et al. 2012/2013) of uncharred remains. In the infill of the Mohelnice well, charred macroremains were completely missing (Opravil 1979a; 1979b). These data make it possible to reconstruct crop husbandry practices and subsistence strategies of the first farmers. Cultivated plants found in the Uničov well represent only $3 \%$ of the plant macroremains assemblage, and this part of the collection was clearly dominated by einkorn wheat (Triticum monococcum) and emmer wheat (Triticum dicoccum). The well infill contained much more glumes than would correspond to the natural ratio of spikes from the two aforesaid wheat species (Hillman 1981), so we can assume that both types of wheat rather represent waste from the sieving of cereals. However, the interpretation is not (Triticum durum/turgidum) entirely clear. The well's infill also contained a large number of small grain fragments of undetermined cereals (Cerealia). In addition to Triticum monococcum and Triticum dicoccum, a third type of wheat was also identified. However, this fine-grained tetraploid wheat (Triticum durum/turgidum) was not very significant for the first farmers' economy. Its importance did not increase until the Late Iron Age (Dreslerová - Kočár 2013).

Based on these results, we can assume that both wheat species were cultivated, processed and stored for a long time. The glumes/spikelet forks-to-grains ratios in the Uničov well infill are very similar in Triticum monococcum and Triticum dicoccum. However, separate handling cannot be excluded. The charred waste could only have landed in the well infill after the threshing of grains. The joint occurrence of both wheat species at the Neolithic sites of Central Europe, for example Eythra well no. 17 (Herbig et al. 2012/2013), ErkelenzKückhoven and Brodau (Zerl - Herbig 2012), is so frequent that their mixed cultivation is sometimes considered (Bogaard 2004, 64; Hajnalová 2012, 100). The storage of cereals is confirmed by the find of the wheat weevil (Sitophilus granarius), which is a synanthropic insect that develops in grains of stored cereals (Plarre 2010). It has previously been found in other Neolithic wells such as those at Erkelenz-Kückhoven (Schmidt 1998), Leipzig-Plaußig (Schmidt 2017) or Droßdorf (Schell - Herbig 2018). Small and heavy seeds (Cerastium fontanum, Echinochloa/Setaria, Poaceae, Potentilla sp. and Setaria sp.) and large and light seeds (Asteraceae, Bromus sp.) predominate in the assemblage of weed diaspores from the infill of the well described here, confirming the hypothesis of the fine sieving of cereals (Jones 1984).

We only identified a few species of typical cereal weeds (Agrostemma githago, Galium spurium). The oldest find of an Agrostemma githago seed in Czechia points to the origins of the spread of this typical weed, which is mainly associated with winter varieties cereals. The species is a good indicator of cereal cultivation, particularly because it does not grow permanently in ruderal vegetation. A low proportion of this species can signify intensive spring cultivation of winter cereals by 
weeding or hoeing. By contrast, LBK field management has been reconstructed as a simple agricultural system with emphasis on summer crop growing. Permanent fields were cultivated using hoes, digging sticks or similar tools, sown in spring and grazed in autumn and winter. Nevertheless, Triticum monococcum can be grown as a summer or as a winter crop. There also exist summer and winter varieties of Triticum dicoccum (Kreuz Schäfer 2011). Galium spurium, on the other hand, is not clearly ecologically defined, being located somewhere on the transition between cereal weeds and root crops. This species is one of the most common in archaeobotanical assemblages from prehistoric sites in Czechia (Pokorná et al. 2018). Therefore, it seems that it might also be an important indicator of prehistoric field management. The wells at Erkelenz-Kückhoven and Brodau predominantly contained a stable spectrum of weeds, which demonstrates relatively uniform cereal cultivation in western and central Germany (Zerl - Herbig 2012).

The fossilization conditions in the Uničov well also enabled the preservation of other crop plants, namely poppy (Papaver somniferum/setigerum) and flax (Linum usitatissimum). The seeds of Papaver somniferum/ setigerum represent one of the oldest records of this crop in Czechia. Seeds of Papaver somniferum/setigerum have so far only been found in the Velim well (Chlup et al. in preparation) and at the Těšetice-Kyjovice settlement (Vostrouská et al. 2019). No rich find of this crop is known from the Neolithic period in Czechia, so the cultivation of Papaver somniferum/setigerum remains to be proved. Rich finds are documented from the Neolithic wells in Germany. More than 3,500 seeds have been found in five wells at Eythra, Leipzig-Plaußig, Brodau and Schkeuditz-Altscherbitz (Herbig et al. 2012/ 2013). An assemblage of more than 6,000 seeds of Papaver somniferum was obtained from the ErkelenzKückhoven well (Knörzer 1998). Only two seeds of Linum usitatissimum were found in the Uničov well. The Velim well, on the other hand, yielded over 30 seeds of Linum usitatissimum and secondary usage of the well as a steeping pit is assumed (Chlup et al. in preparation). Linum usitatissimum has also been documented in the wells at Erkelenz-Kückhoven and Brodau (Zerl - Herbig 2012). Other crops, such as pea (Pisum sativum) and lentil (Lens culinaris), are commonly known from LBK settlements in Czechia (Dreslerová - Kočár 2013). However, they were not found in the Uničov well, although they were identified in plant macroremains assemblages from the wells at Velim (Chlup et al. in preparation), Erkelenz-Kückhoven and Brodau (Zerl - Herbig 2012).

Besides being a source of timber and firewood, woodlands could also be used as a source of fruits and plant medications (Dreslerová - Sádlo 2000; Dreslerová 2012). Gathering was not primarily done in woodland stands, but mainly in open-canopy shrublands, forest-steppes and grazed woodlands, clearings and open-canopy woodland stands or woodland edges. A large number of cracked hazelnuts (Corylus avellana) was found in the Uničov well's infill. Isolated finds of strawberry (Fragaria vesca, Fragaria cf. moschata) and raspberry (Rubus idaeus) diaspores suggest knowledge of other fruit plant species. However, no clear proof of gathering has been produced. Apple seeds (Malus sylvestris) were also found. Surprisingly, fruits of the bladder cherry (Physalis alkekengi) was gathered, too. This species could be used as a medicinal plant or delicacy. It grows in deciduous forests and synanthropic habitats. Analogous finds are known from Neolithic wells in Saxony (Herbig et al. 2012/2013). The find of this plant at Uničov may provide a clue as to the possible origin of this species in Czechia.

Nettle leaves (Urtica dioica) or mint leaves (Mentha cf. aquatica) could be gathered in the undergrowth of alder trees. In particular, a number of plant species growing on the floors of sparse woodlands could be a source of herbal remedies (e.g. Hypericum perforatum, Origanum vulgare, Plantago major, Nepeta cataria and cf. Verbascum sp.). The obtained evidence of elderberry seeds (Sambucus nigra) probably came from ruderal or alluvial vegetation, but the species is also a source of edible fruits and medicinal flowers. Acorns could also be gathered. However, only one piece of acorn of common oak (Quercus cf. robur) was identified.

\subsection{Landscape and vegetation in the Early Neolithic period}

The results of our archaeobotanical analysis span a range of natural habitats and vegetation types. Firstly, the presence of aquatic species, such as Potamogeton sp. and Batrachium sp. and both genera of Charophyta green algae, Chara sp. and Nitella sp., proves a water surface habitat directly in the well, which seems surprising considering its size. Nevertheless, temporary drying out is sufficient for the occurrence of these plants. Evidence of their occurrence is also known from other Neolithic wells in Saxony, for example Eythra wells no. 17 and 21/22, Leipzig-Plaußig and Schkeuditz-Altscherbitz (Herbig et al. 2012/2013). Birds were the most probable vectors for the transport of seeds of aquatic plants (Green - Figuerola - Sánchez 2002). This might also be true of other wetland species such as Iris pseudacorus, Mentha aquatica and Ranunculus sceleratus. However, birds cannot be invoked as an explanation for the presence of Charophyta algae, as these algae indicate a high content of minerals in the environment. In addition to aquatic and wetland plants in the Uničov well, there was also a significant proportion of animals associated with humid environments (frogs, Arvicola, Microtus oeconomus and Micromys).

Secondly, wastegrounds, field edges or other steppe habitats were evidenced in the vicinity of the well. The Uničov well was filled up intentionally, which led to the occurrence of plants associated with wet and disturbed habitats, such as Chenopodium album and Atriplex sp. They represent more than two-thirds of all seeds in the assemblage under study. By contrast, the proportion of these species in Eythra well no. 21/22 and the well at Leipzig-Plaußig was less than one-third (Herbig et al. 2012/2013). Ruderal vegetation was represented by species such as Polygonum aviculare and Plantago major, which commonly occur on trampled sites. These species are well-known from archaeobotanical records of the LBK period (e.g. Vostrouská et al. 2019). The soil 
in the surroundings of the Uničov well was rich in nitrogen and illustrated the sequence of gradual infilling and vegetation succession. These plant communities represent a transition between natural open habitats and later ruderal communities strictly tied to human settlement. This is supported by the presence of a beetle community that was significantly represented by beetles living in ruderal habitats with nitrophilous vegetation, such as field edges, dung dumps and trampled areas. Moreover, the open-land microfauna (e.g. Cricetus, Microtus, Crocidura and Mustela) predominates in the well infill. During the Middle Holocene, the steppe environment with all of its inhabitants, including voles and hamsters, was almost gone in eastern Central Europe (Horáček - Ložek 1988). In this case, the abundance of the open-land microfauna was undoubtedly related to the occurrence of secondary steppes such as fields. LBK settlement areas were enclaves within open woodlands, shrub thickets and grassy patches (Kočár Pokorná - Sádlo 2018), as has been demonstrated at Těšetice-Kyjovice (Vostrovská et al. 2019).

The third identified habitat was an open-canopy woodland with shrubs on the edges. Around $48.9 \%$ of hazel (Corylus) was detected in anthracological records from all explored LBK wells in Czechia. By contrast, an about 3\% abundance was evidenced in dry conditions within the first farmers' settlements (Opravil 1972; 1977; 1979a; 1979b; Kočárová - unpublished data). The greater abundance of Corylus can indicate a human impact on the surrounding woodland, where it took the place of the pioneer tree replacing the previously dominant Quercus. Another possible explanation of the great abundance of Corylus is the presence of remnants of wickerwork constructions and woven artifacts, which is common under generally dry conditions. This corresponds to evidence from the Mohelnice well (Opravil $1979 a ; 1979 b)$. Corylus exhibits higher abundance also in the pollen record, but it depends on the individual site and region (Jamrichová et al. 2017; Šolcová et al. 2018). Interesting is the contrast between the abundance of Pinus in the natural pollen record (Chytrý 2012) and the scarce occurrence of Pinus charcoals in the anthracological record from LBK settlements in the Czech lowlands. It could be explained by the particular differentiation of the local bedrock such as loess plains or sandy soils (Kočár - Šumberová - Kočárová 2014). Generally, it probably reflects different taphonomy of both proxy records (Novák et al. 2017). The human impact of the first farmers on the surrounding vegetation is under debate (Willis - Bennett 1994). Some studies suppose changes in woodland composition (Magyari et al. 2012), but a regional overview does not show any changes in the vegetation pattern during the LBK period (Petr et al. 2013; Jamrichová et al. 2017). Human impact during the Late Neolithic is only visible on the local scale (Šolcová et al. 2018).

Analysis of timbers revealed the presence of Quercus trees of various ages, from the youngest specimens to 200-year-old trees, in the open-canopy woodland. Their different age and diameter can reflect the dynamics and spatial composition of the woodland. The mosaic structure of the surrounding woodland can be explained by the existence of old Quercus trees, representing the cores of woodland patches, and young Quercus trees and common Corylus, which lined the edges of woodland patches. Some species of the Pomoideae subfamily were also part of open-canopy woodland edges. This structure of vegetation (Petr et al. 2013; Kuneš et al. 2015; Šolcová et al. 2018) allows for the occurrence of light-demanding species and an absence of typical forest species dependant on a closed canopy. It could have preserved the richness of grassland habitats throughout the Middle Holocene (Jamrichová et al. 2017; Divíšek et al. 2020) until a later period of agricultural prehistory (Pokorný et al. 2015).

The last recorded habitat was the nearby alluvium, which had a different character than today. The alluvium was not covered by overbank deposits. This environment was characterized by open-shore gravel-sand benches, which are proved by finds of ground beetles (Carabidae). Thin, columnar oak trunks with wider tree rings possibly originated from the alluvium, where the local wetness conditions were favourable for faster growth. This is also supported by macroremains of the flowering species Myosoton aquaticum, Stellaria cf. neglecta and the diagnostic species of alder forests Lycopus europaeus, Mentha cf. aquatica, Persicaria lapathifolia agg., Scutellaria galericulata and Sium cf. latifolium. An interesting find is Urtica kioviensis, which is tied to alluvial woodlands. Fossil evidence of Urtica kioviensis has rarely been found at other Neolithic sites in Czechia (e.g. Elbe alluvium; Kočár - unpublished data) or in records from the Mesolithic period in northeast Germany (Wolters - Bittmann - Kummer 2005). It illustrates changes in the alluvium during the Holocene period, when the sedimentation of overbank deposits created an oxbow and gravel-sandy bars in the alluvium. Charcoal evidence reflects the vicinity of a river, as does the presence of Salix and Alnus (Novák et al. 2017).

The climate of the LBK period was reconstructed with the same annual average temperature as today, but with milder winters and lower precipitation rates. This led to higher evaporation and an increasing importance of drought stress (Dabkowski et al. 2019). This corresponds to plant species associated with deciduous woodlands, mainly their herbaceous undergrowth, and several saproxylophages, but species with lower environmental demands prevailed. Neither the assemblage of insects itself, nor the occurrence of larval galleries of wood-boring beetles, for example longhorned (Cerambycidae) and ambrosia (Xyloterus sp.) beetles on the timbers from the Uničov well can provide additional independent evidence pertaining to the climate during this time. However, larval galleries of the thermophilic great capricorn beetle (Cerambyx cerdo L.) were detected in $27 \%$ of the timbers from wells in Germany (Tegel et al. 2012).

\section{Conclusions}

Neolithic wooden wells are a remarkable phenomenon because they played an important part in how humans redesigned domestic and public spaces. The active digging of wells reaching the underground water table reflects an innovative approach to water provisioning in sedentary communities. Last but not least, water wells 
and their sedimentary infills are prehistoric archives of palaeoecological data. A unique discovery of one such well has enabled us to study the broad topic of palaeoecology by taking a multi-proxy approach combining a set of methods.

The construction and subsequent usage of the well provably date back to the $51^{\text {st }}$ century $\mathrm{BC}$, that is, the Middle LBK. The internal construction of the Uničov well was composed of four oak corner posts with longitudinal grooves, in which horizontal oak boards were embedded. The whole wooden lining was daubed from the outside with a thick layer of grey clay as a shield sealing against contaminated external water. The water level was accessed through the mouth of a wide funnelshaped pit. The wooden lining itself most probably originally reached down to its bottom. No evidence of any aboveground construction was detected in the upper part of the well. Neolithic wells were usually tube-like or consisted of a chest-like log construction with split wooden planks. Comparable constructions are otherwise only known from the Bronze Age, the Roman period and the Middle Ages. The construction with planks inserted into grooves of corner posts had been unknown for the European Neolithic until the recent find described herein.

A number of different development facies were recognized inside the well's infill. It was possible to indicate which events have taken place there. At the beginning, the infilling process was quick and related to the usage of the well. After it was destroyed and repaired, the well lasted for a longer period of time. We have managed to prove that water was pulled from the well daily, that the well was cleared out and that the original infill was removed during the repair. In the following phase, the environment in the well changed at least once, as the underground water level dropped and then recovered. Finally, the well was backfilled intentionally with material partly consisting of organic waste.

The well infill contained remains of a great number of cultivated crops, weeds and shrub fruits, as well as a rich spectrum of herbs. We can assume intensive spring cultivation of winter cereals, as well as the processing and storage of both wheat species. The cultivation of other crop plants, namely poppy and flax, is also documented. The gathered fruits represent the remains of hazelnut fruits, strawberries, raspberries, apple tree seeds and bladder cherries. Medicinal drugs such as nettle or mint could be gathered in the undergrowth of alder trees. Elderberry was also a source of edible fruits and medicinal flowers. Hazel and oak served as constructional and craft timber or as firewood. Oak acorns were also possibly gathered.

The results of our archaeobotanical analysis span a broad range of natural habitats and vegetation types. Firstly, the presence of aquatic species proves a water surface habitat directly in the well. Secondly, there is evidence of waste grounds, field edges or other steppe habitats. The well was probably filled in intentionally, which led to occurrence of plants associated with wet and disturbed habitats. The soil in the surroundings of the well is rich in nitrogen and illustrates the sequence of gradual infilling and vegetation succession. The third identified habitat is an open-canopy woodland with shrubs lining its edges. The increased abundance of hazel possibly indicates that humans influenced the surrounding woodland, where it took the place of the pioneer tree replacing oak, which dominated previously. The mosaic structure of the surrounding woodland can be explained by the existence of old oak trees representing the cores of woodland patches and young oak trees and common hazel lining the edges of woodland patches. The last recorded habitat is the nearby alluvium, which was characterized by open-shore gravel-sand benches. Thin columnar oak trunks with wider tree rings possibly originated from the alluvium, where the local wetness conditions were favourable for faster growth. The first farmers' settlement area at Uničov was an enclave among open woodlands, shrub thickets and grassy patches. We can reconstruct the site environment as a farming village in a mosaic-like landscape forested and forest-free areas such as xerothermic pastures and a river in the surroundings. Our palaeoecological reconstruction has only local interpretative utility, but the general ecological relationship between biological proxies or even species can significantly contribute to our knowledge of the environment inhabited by the first farmers in eastern Central Europe.

\section{Acknowledgements}

We would like to thank the anonymous reviewers for their help, insightful comments and suggestions. We also thank Jana Kličová and Frederick Rooks for translations and language revisions of our text.

This work was supported by the Czech Science Foundation under the grant entitled 'The origin of the cultural landscape in Moravia: investigation of the unique Neolithic well from Uničov' (GAČR 17-11711S). Jan Petřík appreciates the use of the infrastructure supported by the Ministry of Education, Youth and Sports of the Czech Republic (projects LM2015078 and Z.02.1.01/0.0/0.0/16_013/0001708).

English by Jana Kličová and Frederick Rooks

\section{Souhrn}

\section{1. Úvod}

Aktivní hloubení trvalých studen dosahujících $\mathrm{k}$ hladině podzemní vody odráží inovativní přístup k získávání vody v komunitách prvních zemědělcủ. Tyto studny jim zajištovaly vlastní zásobování vodou a zemědělci se tak nemuseli spoléhat pouze na místní srážky. Voda ve studni je izolovaná a kontrolovatelná, na rozdíl od vody v řece, která je náchylná ke znečištění lidmi nebo zvířaty. Studna mohla také fungovat jako statutární symbol, tedy odrážet nadřazenost určitých osad nad ostatními (Garfinkel - Vered - Bar-Yosef 2006). Kolem poloviny 6. tisíciletí př. Kr. došlo k přechodu na neolitický způsob života ve středním Podunají (Bánffy - Oross 2010) a za 100-200 let se nový způsob života rozšiřil do východního Rumunska a také přes střední Evropu až do východní Belgie. Tyto první zemědělské komunity jsou označovány jako kultura s lineární keramikou (Linearbandkeramik, LBK), která je pro region střední Evropy datována absolutně do období 5500-4950 př. Kr. (Kuča et al. 2012), zejména do intervalu cca 5400-4800 př. Kr. (Manning et al. 2014, 1077). ${ }^{2}$

\footnotetext{
2 Studovaná oblast zahrnuje střední a severozápadní Evropu. Počáteční a konečná data se odhadují pomocí tří různých metod, doplněných průměrem a standardní odchylkou za použití vylepšeného normálně distribuovaného modelu.
} 
První ze studní se zachovanou dřevěnou konstrukcí přiřazených LBK na našem území byla nalezena v osadě v Mohelnici na Moravě v roce 1970 (Tichý 1972). Studny bez dřevěné konstrukce byly odkryty v Mostě v severozápadních Čechách v roce 1976 (Rulf - Ve límský 1993) a v Brně-Bohunicích v roce 2007 (Přichystal 2008). Za posledních pět let byly objeveny tři další studny a všechny měly dřevěnou konstrukci: v Uničově na Moravě v roce 2015 (obr. 1; Ka lábek 2016), ve Velimi ve středních Čechách v roce 2016 (Chlup 2017) a v Ostrově ve východních Čechách v roce 2018 (Sedláček et al. 2019). V celé Evropě bylo zdokumentováno více než 100 studní z 53 časně neolitických lokalit (obr. 2; Windl 1998; Zimmer mann 2009; Tegel et al. 2012; Füzesi et al. 2015; Király - Tóth 2015; Kretschmer et al. 2016; Weiner 2016; Fülöp et al. 2018; Stäuble 2018 , 78). Několik evropských LBK studní bylo publikováno velmi podrobně (Weiner 1994; Koschik 1998; Herbig et al. 2012; Zerl Herbig 2012; Tinapp - Schneider - Stäuble 2013; Stäuble - Veit 2016; Friederich 2017). Naproti tomu z celkového počtu šesti LBK studní v České republice nebyla žádná $z$ nich zatím podrobně vyhodnocena a publikována. Existují však některé chronologicky mladší studny, které byly analyzovány pomocí přístupu multiproxy (Pleinerová 2005; Sedláček et al. 2008; Hajnalová et al. 2018).

Studny a jejich sedimentární výplně mohou poskytnout informace o využívání vody, tesařské práci a o výživě a hospodářstvi prvních zemědělců, jejichž strava byla založena na plodinách jako je pšenice jednozrnka a dvouzrnka, hrách, čočka, mák (Kreuz et al. 2005; Salavert 2011) a na mase chovaného skotu a prasat (Hachem 2018). Studny jako environmentální archiv však svědčí především o životním prostředí a krajině na počátku neolitu. Moravská nížinná krajina byla pokryta mozaikou lesů s otevřeným zápojem a otevřených stanovišt (Petr et al. 2013; Kuneš et al. 2015; Jamrichová et al. 2017; Dudová et al. 2018). Klíčovým faktorem pro variabilitu stanovišt od nivních lesů (Petr - Novák 2014) po stepní enklávy (Pokorný et al. 2015) jsou místní environmentální gradienty, jako je skalní podloží, vlhkost nebo expozice svahu. Environmentální materiál byl systematicky odebírán, podroben flotaci a publikován pouze $\mathrm{z}$ několika nedávno zkoumaných lokalit LBK ve střední Evropě (např. Novák - Krasnokutská 2009; Lenneis 2010; Hajnalová 2011; Vostrovská et al. 2019). Off-site záznam paleoekologického proxy dokládá smíšený listnatý les. On-site data jsou druhově velmi chudá, rekonstrukce krajiny je téměř vždy identická a naopak svědčí většinou o otevřených stanovištích s keři.

Archeologický záchranný výzkum v lokalitě Uničov - U kravína odhalil LBK osadu s dřevěnou studnou. Naším primárním cílem je rekonstruovat proces stavby studny. Za druhé se pokusíme prozkoumat využívání studny až $\mathrm{k}$ jejímu zániku a hospodaření s vodou v první zemědělské společnosti. Za třetí chceme také zjistit, které rostliny první zemědělci jedli a jaké dřevo použili pro stavbu studny nebo jako palivo. Čtvrtým cílem je prozkoumat, jak vypadalo místní prostředí a jak jej první zemědělci mohli ovlivnit, do jaké míry se prostředí v neolitu změnilo a kdy se pravěká krajina na Moravě změnila v kulturní krajinu. K řešení těchto otázek byla použita kombinace různých metod vycházejících $\mathrm{z}$ archeologie i biologických a geovědních oborů.

\section{Materiál a metody}

\subsection{Popis lokality}

Lokalita se nachází cca 230 m od levého břehu potoka Lukavice. Dalším tokem je potok Oskava ve vzdálenosti přibližně $1100 \mathrm{~m}$, přítok řeky Moravy zahrnující široké lužní území ve výšce 233234 m n. m. (obr. 3). Výzkum odhalil jednu část sídelního areálu LBK s 12 dlouhými domy s pětiřadou sloupovou konstrukcí, stavební jámy, nepravidelné hliníky, zásobní jámy a pece. Výjimečným nálezem byla studna se zachovalým dřevěným obložením (obj. 184). Studna byla umístěna $\mathrm{v}$ bezprostředním sousedství domu S2 a domu S3 (obr. 4).

\subsection{Terénní práce}

Po odstranění nadloží měla studna pưdorys oválné jámy o velikosti 580 x $550 \mathrm{~cm}$, orientované na SV-JZ (obr. 5). Výkop byl proveden příčně v protilehlých částech (obr. 6). Ve výplni studny ve tvaru trychtýř bylo nalezeno celkem 110 keramických fragmentů (obr. 7: 1-15). Asi o $1 \mathrm{~m}$ hlouběji se nálevkovitá jáma náhle změnila na téměř svislou šachtu sahající do hloubky $325 \mathrm{~cm}$. Uprostřed této šachty byl detekován tmavě černý jílovitý nepravidelný kosočtve- rečný půdorys, který naznačoval původní dřevěnou konstrukci studny. V šachtě studny byly nalezeny pouze dvě celé keramické nádoby a 11 fragmentů keramických nádob (obr. 7: 16-23). Dřevěné obložení šachty bylo na vnější straně omazáno asi $6 \mathrm{~cm}$ vrstvou šedého jílu (obr. 8) a bylo v něm nalezeno celkem devět keramických fragmentů (obr. 7: 24-26). Hladina spodní vody byla dosažena v hloubce $170 \mathrm{~cm}$ v místě, kde se začala objevovat zachovaná dřevěná konstrukce studny. Tato konstrukce pokračovala do hloubky $320 \mathrm{~cm}$. Celá výplň šachty byla vybrána po mechanických 10 nebo $20 \mathrm{~cm}$ vrstvách do hloubky $325 \mathrm{~cm}$. V hloubce $260 \mathrm{~cm}$ byly provedeny dva paralelní vrty, aby byla zjištěna přesná stratigrafie zbytku výplně studny.

\subsection{Dendrochronologie a radiokarbonové datování}

Celkem bylo měřeno 16 vzorků pomocí měřicího systému VIAS TimeTable vytvořeného SCIEM (@ SCIEM). Série letokruhů (TRW) byly měřeny s přesností $0,01 \mathrm{~mm}$ a synchronizovány pomocí softwaru PAST4 (@ SCIEM). Průměrné série TRW byly datovány podle dubové chronologie TRW ze Saska (Tegel et al. 2012). Stupeň podobnosti řady TRW byl hodnocen t-testy (Gleichläufigkeit: Eckstein - Bauch 1969; TBP: Baillie - Pilcher 1973; THO: Hollstein 1980). Anatomické stanovení dřevin bylo založeno na následující literatuře: Schweingruber (1990a; 1990b), Grosser (2007) a klíč k identifikaci dřevin podle Schocha (Schoch et al. 2004).

Pro radiokarbonové datování bylo odebráno celkem 20 vzorků z konstrukce a výplně studny. Materiál byl analyzován za použití AMS v laboratořích Isotoptech Zrt. Debrecen, Labor für Ionenstrahlphysik ETH Zürich a Curt-Engelhorn-Zentrum Archäometrie Mannheim. Získaná data byla kalibrována pomocí OxCal verze 4.3 $(95,4 \% \pm 2 \sigma ; \mu \pm 1 \sigma)$.

\subsection{Doklady opracování}

Na všech 47 kusech dřeva $z$ konstrukce a výplně studny se nacházely stopy po opracování. Pro všechny předměty byly vytvořeny měřítkové výkresy pro zkoumání dendrologických parametrů a pro stanovení jejich polohy v kmeni. $Z$ této informace byly získány minimální prưměry dříku a indikace podélných procesů štěpení. Výrobní postupy byly identifikovány na základě techno-morfologických znaků a po konzultaci s archeologickým (např. Böhm - Pleyer 1990; Weiner - Lehmann 1998; Elburg 2008; Tegel et al. 2012) a etnoarcheologickým výzkumem (např. Pétrequin - Pétrequin 1993), jakož i s experimentálními studiemi a zkušenostmi (Meier 1990; Choulot et al. 1997; Arnold 2003; Lobisser 2005; Elburg et al. 2015). Výsledky těchto analýz byly vyhodnoceny v Jahrringlabor der Professur für Waldwachstum und Dendroökologie der Universität Freiburg.

\subsection{Litostratigrafie}

Základní makroskopický popis byl proveden na místě a při odběru vzorků $z$ vrtných jader v laboratoři. Rozpoznané vrstvy byly podrobně analyzovány na výbrusových preparátech ze vzorků sedimentu. Výbrusy byly analyzovány polarizačním mikroskopem podle standardních postupů (Bullock et al. 1985; Stoops - Eswaran 1986; Stoops 2003). Magnetická susceptibilita byla měřena za použití zařízení Agico Kappabridge MFK1-FA. Chemické složení bylo stanoveno pomocí ED-XRF spektrometru.

\subsection{Palynologie}

Všech 28 vzorků bylo zpracováno za použití standardní metody acetolýzy (Moore - Webb - Collingson 1991) pro analýzu pylu. Pro jednotlivé vzorky byl použit přibližně $1 \mathrm{~cm}^{3}$ sedimentu. Pro identifikaci pylových zrn byl použit pylový atlas (Beug 2004). Pro vykreslování pylových diagramů byl použit program POLPAL (Walanus Nalepka 1999).

\subsection{Antrakologie, xylotomie, rostlinné makrozbytky, mechy, zoologie a entomologie}

Celkem 57 vzorků sedimentu bylo získáno při vybírání výplně šachty. Všechny vzorky byly prosety za mokra na sítu s oky o velikosti $2 \mathrm{~mm}$ a hrubá frakce byla roztříděna na uhlíky, fragmenty dřeva a velká semena. Pouze 20 vzorků o objemu 21 bylo také zpracováno na sítu s oky o velikosti 0,25 mm kvůli vysoké koncentraci 
environmentálního materiálu (Pearsall 2001). Celkem bylo zpracováno 5721 sedimentu. Environmentální materiál byl roztříděn a identifikován pod stereomikroskopem.

Fragmenty byly analyzovány pomocí interferenčního mikroskopu s episkopem se zvětšením 50x, 100x a 200x. Celková hmotnost uhlíků v každém vzorku byla zvážena s přesností na $0,001 \mathrm{~g}$ (Talon - Carcaillet - Thinon et al. 1998). Identifikace dřevin, včetně uhlíků, byla provedena podle Schweingrubera (Schweingruber 1990a; 1990b).

Soubor rostlinných makrozbytků pochází z 20 vzorků. Semena, plody a další rostlinné makrozbytky byly vytříděny $z$ vlhkých prosetých vzorků. Stanovení bylo provedeno pomocí referenčního sběru, atlasů a klíčủ k semenům (Anderberg 1994; Berggren 1981; Beijerinck 1947; Cappers - Bekker - Jans 2006; Jacomet 2006).

Nomenklatura mechů vychází z posledního vydání kontrolního seznamu a Červeného seznamu mechorostů České republiky (Kučera - Váña - Hradílek 2012).

Soubor mikrofauny byl analyzován standardními metodami archeozoologie (Reitz - Wing 2008). Stanovení kostí bylo provedeno pomocí osteologického sběru i osteologických atlasů (Schmid 1972 Anděra-Horáček 1982; Červený - Komárek - Štěrba 1999). Vzhledem $\mathrm{k}$ malé hmotnosti fragmentů byl v př́padě souboru získaného plavením detekován pouze počet nálezů a minimální počet jedinců kvantifikační metody v archeozoologii viz Kyselý 2004.

Zbytky hmyzu byly identifikovány podle srovnávacích sbírek a moderních klíčủ jednotlivých skupin. Jednotlivci ve shromáždění byli kvantifikováni metodami počet identifikovaných vzorků (NISP) a minimální počet jednotlivců (MNI; Lyman 2008).

\section{Výsledky a interpretace}

\subsection{Dendrochronologie a radiokarbonové datování}

Dřeva ze zachované dřevěné konstrukce poskytla devět absolutně datovaných sérií dubu (Quercus spp.). Počet letokruhů bělového dřeva detekovaných ve vzorcích spadá do rozmezí definovaného O. Prokopem (Prokop et al. 2017). Stromy použité pro stavbu studny byly pokáceny mezi 5093 a 5085 př. Kr. (Rybníček et al. 2018, 100-101).

Po kalibraci radiokarbonových dat spadá dřevěná konstrukce a výplň studny do širokého intervalu 5464-4615 cal. BC (tab. 1) Výsledek odpovídá dendrochronologickému datování. Údaje zí skané z nažek, semen a obilovin z výplně (5302-4979 cal. BC) a dřeva $z$ konstrukce (5290-5026 cal. BC) jsou srovnatelné (obr. 9).

\subsection{Trasologie}

Všech 47 zkoumaných dřev bylo klasifikováno jako dub (Quercus sp.). Dubová konstrukce byla založena na čtyřech rohových kůlech. Každý z těchto kůlů byl vybaven dvěma podélnými na sebe kolmými drážkami. Do těchto drážek byla zasazena prkna. Konce jednotlivých prken byly zkosené, takže dobře zapadly do drážek rohových kůlů. Konstrukce studny měla celkem čtyři zachované zdi, ve kterých bylo umístěno 7-9 kusů prken. Zachovaná konstrukce studny měla výšku 86-126 cm (obr. 10). Pod stěnami konstrukce byly ve vnitřním prostoru šachty detekovány nepravidelně umístěné kủly. Tři prkna měla pravý konec uvolněný z drážky rohového kůlu.

Většina zkoumaných dřev (tab. 2) představuje radiálně štípané dřevo. Kulaté dřevo bylo použito ve dvanácti případech, zejména u svislých kůlů (obr. 11-13). Ve dvou případech byla prkna štípána tangenciálně (obr. 16-17). Šírka drážek na rohových kůlech se pohybovala mezi 3,5 a $7 \mathrm{~cm}$, hloubka byla 4 až $6 \mathrm{~cm}$. V jednom př́padě (obr. 12) bylo možné změřit výšku střední části dělící dvě drážky $(2,5 \mathrm{~cm})$. Na stejném kusu dřeva byl pozorován opracovaný hrot Tlouštka radiálně štípaných prken se pohybuje mezi 3 a $8 \mathrm{~cm}$, tlouštka tangenciálních prken (obr. 16-17) je přibližně 8 nebo $9 \mathrm{~cm}$. Směrem k oběma koncům mají prkna oboustranně zkosené hrany. které zmenšují tlouštku desek na 1-2,5 cm (obr. 16). Povrch prken byl upraven plochým tangenciálním příčným sekáním (obr. 15), přičemž stopy sekání, pravděpodobně pomocí kopytovitých klínů, zůstaly patrné. Širší stopy byly pozorovány pouze u tangenciálně štípaného dřeva č. 723 (obr. 16). V tomto případě se však jedná spíše o stopu hrubého zpracování než o opracování konce prkna. V jednom případě bylo pozorováno oddělení po celé délce prkna (obr. 14). Na dvou kusech dřeva byly identifikovány stopy po hmyzu (obr. 15-16).

\subsection{Litostratigrafie}

Výplň studny byla makroskopicky rozdělena do pěti litostratigrafických jednotek (popis jednotek viz obr. 19). Na základě mikroskopického studia výbrusů bylo identifikováno devět sedimentárních facií (obr. 20). Charakteristiky jednotlivých facií jsou uvedeny v tab. 3.

Facie $1(343-336 \mathrm{~cm})$ byla identifikována pouze na dně studny a je tvořena písčitým materiálem. Vznikla velmi rychle během stavby studny nebo jejího čištění či opravy. Následně byla překryta dobře vytříděným prachovitým sedimentem (facie 2, 336-299 cm a $296-282 \mathrm{~cm}$ ), který se uložil v relativně klidném vodním prostředí a pravděpodobně byl homogenizován při čerpání vody ze studny. Zdrojem materiálu byly starší nivní sedimenty a pravděpodobně také eolický prach, který padal do otevřené studny. Facie 3 (299$298 \mathrm{~cm}$ ) byla popsána jako písčitý prach obsahující kanálky po kořenech rostlin, které dokládají dočasné vyschnutí studny. V sedimentu byly př́tomny fragmenty uhlíků, jež ukazují na antropogenní aktivity v okolí studny. Následující facie $4(298-297 \mathrm{~cm})$ je tvořena světlým heterogenním prachovým materiálem, který se pravděpodobně dostal do studny $\mathrm{v}$ důsledku napadání půdy $\mathrm{z}$ okolního povrchu. Facie 5 (297-295 cm) se vyznačuje jemnou laminací, která odráží opakující se cyklus sedimentace jemného jílového nánosu a prachu (režim využívání studny nebo vliv silných deštů). Facie $6(282-275 \mathrm{~cm})$ se skládá $z$ hrubého prachu s př́měsí rozloŽené organické hmoty. $Z$ velkého množství organické hmoty lze usuzovat, že voda ve studni byla v této době silně eutrofizovaná. Přítomnost pískových mikrolamin ve facii $7(275-274 \mathrm{~cm})$ vznikla v důsledku opakovaného čerpání vody, i když voda ve studni již nebyla čistá. Facie $8(274-180 \mathrm{~cm})$ je tvořena tmavým hrubým prachem. Heterogenní charakter výplně naznačuje spíše rychlé, dokonce jednorázové uložení materiálu, které vyplnilo větší část šachty studny. Mohlo se jednat o úmyslné zasypání studny. V době vzniku této facie již studna nesloužila původnímu účelu. Svrchní část dokumentované výplně studny vyčleněná jako facie 9 (180$160 \mathrm{~cm}$ ) byla ovlivněna pedogenozí.

Oscilace zrnitosti způsobené disturbancemi sedimentů ve studni, případně změnou zdroje materiálu je možné sledovat na křivce poměru křemíku (Si) a hliníku (Al). Facie $2-5$ vykazují od hloubky cca $320 \mathrm{~cm}$ mírně zvýšené hodnoty frekvenční magnetické susceptibility (Kfreq), a především výrazně zvýšené hodnoty hmotnostní magnetické susceptibility (KMass), které korelují se zvýšeným obsahem vápníku (Ca). Poslední fáze přítomnosti vody ve studni a jejího možného využívání jsou spojovány s faciemi 6 a 7, které vykazují maxima v poměru křemíku (Si) a hliníku (Al) a zvýšený vápník (Ca). Zvýšené hodnoty fosforu (P) a síry (S) jsou patrné na bázi facie 8 a ve facii 9 , které jsou interpretovány jako zásyp studny s doklady pedogeneze ve svrchní části.

\subsection{Palynologie}

Pylová zrna jsou celkem dobře zachována, ale ve velmi nízké koncentraci. Pylový záznam zahrnuje tři výrazné litostratigrafické vrstvy (obr. 21). Spodní šedá písčito-jílovo-prachovitá vrstva v hloubce 330-300 cm (facie 2) obsahuje pyl borovice (Pinus), Cyperacae a Gramineae. Smrk (Picea) je běžný, ale listnáče chybí s výjimkou lísky (Corylus) a olše (Alnus). Pyl obilnin je také vzácný, stejně jako pyl typu Helianthemum, který je v pozdní době ledové velmi běžný, ale ve spektru pylů holocénu je raritní. Neobvyklý je typ Juglans, který lze dokonce považovat za terciární redepozici. Zachycené zelené řasy jsou typické pro studená jezera s nízkou eutrofizací. Jejich hojnost je v umělé studni velmi neobvyklá. Následuje krátká fáze vysušení v hloubce 300-294 cm (facie 3-5).

Další dvě vrstvy jemně písčitá až jílovitá od 294-275 cm (facie 2) a nad ní šedo-černý prachový jíl v hloubce 275-249 cm (facie 8) vykazují odlišné pylové spektrum. Převažujícím taxonem je Corylus, celkem běžné jsou Pinus, bříza (Betula), Picea, jasan (Fraxinus) a Alnus. Zajímavé je nízké množství dubu (Quercus), lípy (Tilia) a jilmu (Ulmus). Toto složení obecně odpovídá pylovému spektru $\mathrm{z}$ př́írodních profilů $\mathrm{v}$ údolí Moravy, které jsou datovány do středního holocénu. Bez (Sambucus nigra) je součástí synantropní vegetace. Vysoká hojnost Corylus mưže naznačovat místní těžené 
lesy. Mercurialis označuje narušenou a čerstvou holou půdu nebo dokonce zahrady. Zajímavá je nízká četnost pylů obilovin dosahujících $5 \%$ z celkového spektra.

Změna v palynologickém záznamu v hloubce $294 \mathrm{~cm}$ perfektně odpovídá přechodu mezi faciemi 2 a 3-5, tedy fázi, která byla interpretována jako vysušení, což dokládá i náhlý úbytek řas. Další litologická změna v hloubce $275 \mathrm{~cm}$ se v palynologickém záznamu neprojevuje.

\subsection{Antrakologie a xylotomie}

Analýzy uhlíků a fragmentů dřeva umožnily identifikovat 15 taxonů (tab. 4). Analýza uhlíků poskytla taxonomicky pestrá data (obr. 22). Vysoký podíl lísky (Corylus) naznačuje keře, které se objevily kolem osady v důsledku hospodářských činností prvních zemědělců (obr. 23). Keřové porosty obvykle následují bezlesá místa v sídelním areálu. Dalšími taxony jsou dub (Quercus) a lípa (Tilia), jasan (Fraxinus), javor (Acer) a olše (Alnus), topol (Populus) a topol/ vrba (Populus/Salix) a jilm (Ulmus).

Soubor dřev obsahoval hlavně fragmenty dubu (obr. 24), pravděpodobně zbytky konstrukčního dřeva. Přítomnost dřeva Alnus a Salix může indikovat růst vlhkomilné vegetace v sousedství studny. Sídelní areál mohl být porostlý dřevinami včetně nitrofilní lípy a na světlo náročné lísky (obr. 25). Dále od osady můžeme předpokládat existenci světlých lesních nebo leso-stepních porostů ovlivněných hlavně pastvou. Ve stromovém patře předpokládáme převážně osamělý Quercus a pod nimi křoví Corylus a podrost s dominancí trav (obr. 26).

\subsection{Rostlinné makrozbytky a mechy}

$Z$ pěstovaných rostlin převládala pšenice jednozrnka (Triticum monococcum) a pšenice dvouzrnka (Triticum dicoccum). Dalšími přítomnými plodinami byla jemnozrnná tetraploidní pšenice (Triticum durum/turgidum) a olejniny, jako je mák (Papaver somniferum/se tigerum; obr. 27: A) a len (Linum usitatissimum; obr. 27: B). Sbírané plody představují zbytky lískových ořechů (Corylus avellana), jahody (Fragaria cf. vesca), semena jabloní (Malus sylvestris) a mochyně židovské třešně (Physalis alkekengi). Celkem 92 \% souboru pocházelo ze synantropních druhů rostlin, zejména z Chenopodium spp. a Urtica dioica (obr. 27: C). Agrostemma githago (obr. 27: D), Hyoscyamus niger (obr. 27: E), Onopordum acanthium (obr. 27: F) byly podobně běžné. Další ekologické skupiny jsou druhy suchých otevřených stanovišt, které jsou jinak v archeobotanickém materiálu LBK v České republice velmi vzácné. Jsou to druhy suchých travních porostů nebo ruderálů a pastvin.

Soubor obsahuje nejstarší doklady několika druhů na území České republiky. Hyoscyamus niger byl znám z osady LBK v Těšeticích-Kyjovicích (Vostrovská et al. 2019). Agrostemma githago je jedním $z$ prvních dokladů specializovaných plevelů zimních obilovin pro neolitické období. Nejstarší doklad byl znám z eneolitu (Kočár - Pokorná - Sádlo 2018; Pokorná et al. 2018). Další je Onopordum acanthium známé $\mathrm{z}$ halštatu, dále Linaria vulgaris, Anthriscus caucalis, Nepeta cataria, které byly doposud známy až od raného středověku (Pokorná et al. 2018). Nakonec je to Physalis alkekengi, která byla zaznamenána ve středověkém (Opravil 1996) a renesančním kontextu (Kočár et al. 2007).

Většina taxonů mechu byla nalezena v hloubce $280-300 \mathrm{~cm}$. V celém profilu studny dominuje mokřadní mech srpnatka zahnutá (Drepanocladus aduncus; obr. 28: A), který je dodnes hojný na nížinných stanovištích se stojatou vodou. Všechny zjištěné druhy pravděpodobně ve studni přirozeně rostly nebo spadly do studny ze stromů nebo domů v okolí. Jedná se o mokřadní, epifytické (např. Anomodon viticulosus; obr. 28: B) a suchozemské mechy. Mech Neckera pennata dnes představuje vzácný epifytický druh, který roste $\mathrm{v}$ našich nejlépe dochovaných lesích. Výpln̆ studny v hloubce 120-140 cm většinou obsahuje zbytky suchozemských mechů; v hloubce 150-250 cm začíná dominovat mokřadní mech Drepanocladus aduncus společně s dalšími hygrofilními druhy a izolovanými zbytky suchozemských mechů; v hloubce 260-325 cm můžeme také identifikovat kromě dosud přítomných vlhkomilných druhů některé sporadické zbytky epifytů.

\subsection{Zoologie}

V souboru byly zaznamenány kosti různých skupin obratlovců: ryby, obojživelníci, plazi, ptáci a savci. Běžné byly zbytky obojživelníků, konkrétně žáby a ropuchy (Bufo viridis, Bufo sp., Rana arvalis, Rana sp., Anura). Z hmyzožravců byly objeveny zbytky rejsků a bělozubek: Crocidura suaveolens, Crocidura sp., Sorex cf. araneus, Sorex cf. minutus a Soricidae. Byl zjištěn pouze jeden druh masožravců, a to lasice kolčava (Mustela nivalis). Ve studni se objevily hojné zbytky hlodavců. Nález Microtus oeconomus v Uničově je jedním $z$ nejmladších $z$ České republiky, protože během neolitu tento druh vlhkých stanovišt tundry mizí (Horáček - Ložek 1988). Co se týče tafonomie souboru, nebyly zaznamenány žádné nálezy se stopami po řezání nebo ohlodání, zatímco v šesti případech se objevilo opálení.

\subsection{Entomologie}

$Z$ hmyzu představovalo největší skupinu 380 jedinců Coleoptera (obr. 29). Další zaznamenané taxony byly Hymenoptera, Heteroptera a Auchenorrhyncha. Analyzované vzorky také obsahovaly šest vzorků roztočů (Acari, hlavně Oribatida). Identifikované druhy hmyzu naznačují přítomnost pestré mozaiky stanovišt: narušené postupně zarůstající stanoviště, pastviny, travní porosty, lesy a různé typy stanovišt říčních břehů. $\mathrm{V}$ materiálu byly přítomny jak rozšířené, tak nenáročné druhy ruderálů a okrajů polí (Bembidion lampros a Chrysolina fastuosa), jakož i stenoidní brouci přirozeně bohatých teplých a suchých stanovišt a stepí (Centricnemus leucogrammum a Pleurophorus sp.). Nízká četnost lesních druhů (např. Molops piceus) a naopak vyšší hojnost koprofágů vázaných na pastviny (Onthophagus spp. a Aphodinae) pak naznačuje přítomnost spíše otevřených travních porostů s dřevinami (Hellqvist 1999; Whitehouse - Smith 2014). V okolí byla pravděpodobně zastoupena také přirozeně bohatá stanoviště říčních břehů (Dyschirius). Na dřevěných prvcích konstrukce studny byly zjištěny požerky tesaříkovitých (Cerambycidae) a dřevokazů (Xyloterus sp.).

\section{Diskuse}

\subsection{Konstrukce a fungování studny}

Stavba i následné využití studny jsou datovány do 51 . století př. Kr. Porovnáme-li výsledky dendrochronologického datování nedávno zkoumaných studní LBK v České republice, uničovská studna $z$ let 5093-5085 př. Kr. je nejmladší. Starší je velimská studna z přelomu 5196/5195 př. Kr. (Rybníček et al. 2018, 100101) a nejstarší je studna $z$ Ostrova $z$ přelomu 5256/5255 př. Kr. (Rybníček et al. 2020). Další evropské LBK studny, ze kterých byla získána dendrodata, spadají do podobného časového intervalu (Tegel et al. 2012; Kretschmer et al. 2016; Friedrich 2017, 421-440).

Stavitelé studny pravděpodobně předpokládali, že hladina podzemní vody v tomto místě bude díky nedalekému toku snadno dostupná, což dokládá i zjištěná vegetace. Uničovská studna se nacházela v bezprostředním sousedství dvou domů na východním okraji osady. Ukotvení studny v kontextu sídliště je však obtížné. Podle radiokarbonového datování je výplň studny pravděpodobně starší než zkoumaná část sídliště (nepublikovaná data I. Vostrovské). Chronologický horizont prozkoumaného sídliště tedy není současný se studnou. Zdá se, že studna byla současná s nezjištěnou částí sídliště, nebo že lidská činnost z doby stavby a fungování studny není archeologicky detekovatelná.

Neolitické studny ve střední Evropě byly většinou stavěny $z$ dubového dřeva (Tegel et al. 2012) a stejně tak i studna z Uničova. Vybrané duby byly pokáceny kopytovitými klíny a kmeny stromů pak musely být rozřezány na kusy a odkorněny. Prưřezy stavebních dřev a průběh letokruhů dokazují, že kmeny byly většinou děleny radiálně. Stopy po opracování lze pozorovat na každém kůlu a zkosených koncích vodorovných desek z Uničova (Rybníček et al. 2018 , 101). Vnitřní konstrukce uničovské studny se skládá ze čtyř rohových kůlů s podélnými drážkami, do kterých byly zapuštěny vodorovné desky. Ve spodní části šachty byl nalezen jeden kůl, o který se opíraly tři desky, jejichž pravý konec vypadl z drážky rohového kůlu. Jedná se o přímý doklad opravy konstrukce. Dřevěné konstrukce neolitických studní byly obvykle srubové nebo byly tvořeny dutým kmenem stromu (např. Tegel et al. 2012). Drážková 
konstrukce byla, kromě LBK studny z Ostrova (Rybníček et al 2020), známa pouze $z$ doby bronzové, doby římské a ze středověku (Gollnisch-Moos 1999; Rageth 1986; Tegel et al. 2012).

Dno studny v Uničově nebylo upraveno ani zpevněno. Dřevěná konstrukce studny byla $z$ vnější strany omazána asi $6 \mathrm{~cm}$ silnou vrstvou šedého jílu jako ochrana před kontaminovanou povrchovou vodou. Obdobně byla omazána i konstrukce velimské studny (Chlup et al. in preparation). $\mathrm{V}$ jiných případech byly spáry mezi konstrukčními prvky často ucpány mechem (Weiner 1992b, 32; Einicke 1998, 77; Stäuble - Campen 1998, 8; Elburg-Herold 2010, 24-27; Rösch 2017, 404-405). Při odkryvu uničovské studny nebyly v její horní části detekovány žádné kůlové jamky ani jiné doklady nadzemní stavby. Kosočtvercový půdorys šachty v Uničově byl zjištěn v hloubce $120 \mathrm{~cm}$ pod skrytým povrchem. Tuto situaci interpretujeme tak, že hladina vody byla postupně přístupná ústím široké nálevkovité jámy. Samotná konstrukce pravděpodobně původně začínala ve výše zmíněné hloubce $120 \mathrm{~cm}$. Studna byla zřejmě otevřená. Můžeme s jistotou říci, že ústí studny nebylo zcela zakryto víkem, což potvrzuje analýza mechů a rostlinných makrozbytků.

\subsection{Využití, zaplnění a zánik studny}

Dno studny tvoří písčitá výplň související s její stavbou nebo opravou a čištěním. Následuje vrstva s dobře vytříděným prachovitým sedimentem souvisejícím s ukládáním prachu ze starších nivních sedimentů a pravděpodobně také nafoukaného prachu $\mathrm{z}$ okolí studny. Tento sediment byl homogenizován každodenním vytahováním vody ze studny. Výplň ze dna do hloubky $300 \mathrm{~cm}$ neobsahuje mnoho uhlíků, rostlinných makrozbytků nebo hmyzu, což svědčí o čistotě vody během používání studny po opravě. V následující fázi se prostředí ve studni alespoň jednou změnilo na bahnité, prorostlé kořeny, což naznačuje, že hladina podzemní vody klesla. Zvýšení hladiny vody bylo následováno několika fázemi mikrolaminace, které mohou odkazovat na rưzné využití studny v jednotlivých fázích nebo na možný vliv meteorologických jevů, jako je silný déšt. Př́itomnost mokřadních rostlin a mechů rovněž podporuje úvahu o kolísání hladiny vody. Následně v profilu můžeme pozorovat depozici podobného sedimentu jako před vysycháním, ale studna byla pravděpodobně postupně znečištěna organickým materiálem. V této fázi zaplňování studny můžeme také identifikovat zbytky epifytických mechů (hloubka 270-300 cm), které mohly spadnout do otevřené studny z okolních stromů. Podobná situace byla zjištěna u mokřadního sedimentu v Santovce (Šolcová et al. 2018)

Po tomto variabilním stadiu následovalo rychlé, případně jednofázové zaplnění horním horizontem půdy smíchaným se sídlištním odpadem (130-225 cm). To znamená, že studna byla spíše zasypána úmyslně a nezanikla postupným zanášením nebo spontánním zhroucením konstrukce. Tuto myšlenku podporují také výsledky radiokarbonového datování, které nenaznačují postupné zaplnění, ale spíše ukládání smíšeného materiálu rưzného stáří. Materiál $z$ horní tmavé vrstvy výplně studny obsahuje pilouse černého (Sitophilus granarius), který je vázán na rozklad rostlin, takže lze říci, že výplň částečně sestávala $z$ organického odpadu. Svědčí o tom také množství rostlinných makrozbytků a uhlíků v hloubce $180-280 \mathrm{~cm}$. Byly rovněž nalezeny kosti myši domácí (Mus musculus). Tato směs sídlištního odpadu je podobná výplním studní z Erkelenz-Kückhoven a Brodau (Zerl - Herbig 2012). Nejvyšší část zdokumentované výplně studny byla ovlivněna pedogenezí.

\subsection{Strategie obživy prvních zemědělců}

Vlivem mokrého prostředí se zachovaly i nezuhelnatělé rostlinné markozbytky. Kultivované rostliny představují pouze $3 \%$ rostlinných makrozbytků, $z$ nichž jasně dominuje pšenice jednozrnka (Triticum monococcum) a pšenice dvouzrnka (Triticum dicoccum). Identifikován byl i třetí typ, a to jemnozrnná tetraploidní pšenice (Triticum durum/turgidum), která nebyla až do pozdní doby železné příliš významná (Dreslerová - Kočár 2013).

Na základě těchto výsledků můžeme předpokládat dlouhodobou kultivaci, zpracování a skladování obou druhů pšenice, které jsou na neolitických lokalitách střední Evropy tak časté (Zerl - Herbig
2012; Herbig et al. 2012/2013), že se někdy uvažuje o jejich smíšené kultivaci (Bogaard 2004, 64; Hajnalová 2012, 100). Skladování obilovin je potvrzeno nálezem pilouse černého (Sitophilus granarius), který je synantropním hmyzem a vyvíjí se v zrnech skladovaných obilovin (Plarre 2010). Byl nalezen i v jiných neolitických studnách (Schmidt 1998; 2017; Schell - Herbig 2018).

Z typických obilných plevelů jsme identifikovali pouze několik druhů (např. Agrostemma githago). Jedná se o nejstarší nález semene tohoto plevele $\mathrm{v}$ České republice a odkazuje na pưvod jeho šíření. Nízký podíl tohoto druhu může znamenat intenzivní jarní pěstování zimních obilovin. Polní management LBK je rekonstruován jako jednoduchý zemědělský systém s důrazem na pěstování letních plodin. Nicméně Triticum monococcum lze pěstovat jako letní nebo zimní plodinu. Existují také letní a zimní formy Triticum dicoccum (Kreuz - Schäfer 2011). Relativně jednotný management pěstování obilovin byl doložen ve studnách v západním a středním Německu (Zerl - Herbig 2012).

Tafonomické podmínky v uničovské studni umožnily zachování dalších kulturních plodin, konkrétně máku (Papaver somniferum/ setigerum) a lnu (Linum usitatissimum). Semena Papaver somniferum/setigerum představují jeden $z$ nejstarších nálezů této plodiny ve střední Evropě. V České republice byla dosud prokázána pouze ve velimské studni (Chlup et al. in preparation) a na LBK sídlišti v Těšeticích-Kyjovicích (Vostrovská et al. 2019). Bohaté nálezy jsou dokumentovány z neolitických studen v Německu (Knörzer 1998; Herbig et al. 2012/2013). V Uničově byla nalezena pouze dvě semena Linum usitatissimum. Oproti tomu velimská studna poskytla více než 30 semen Linum usitatissimum a předpokládá se zde sekundární použití studny jako močidla (Chlup et al. in preparation). Linum usitatissimum bylo také dokumentováno v německých studnách (Zerl - Herbig 2012).

Sběr ovoce a léčivých rostlin byl prováděn $\mathrm{v}$ keřových porostech, na lesní stepi a lesní pastvině, v lesních porostech a lesních světlých porostech nebo na okrajích lesů. $Z$ výplně uničovské studny pochází velké množství prasklých lískových ořechů (Corylus avellana). Izolované nálezy diaspor jahod (Fragaria vesca, Fragaria cf. moschata) a malin (Rubus idaeus) naznačují znalost dalších druhů plodů. Nalezena byla také semena jablek (Malus sylvestris). Překvapivě byly také sbírány plody mochyně židovské třešně (Physalis alkekengi). Analogický nález je znám z neolitických studní v Německu (Herbig et al. 2012/2013). Nález této rostliny v Uničově může být argumentem pro možný původ tohoto druhu v České republice.

Listy kopřivy (Urtica dioica) nebo listy máty (Mentha cf. aquatica) mohly být sbírány v olšovém podrostu. Nález semen bezu (Sambucus nigra) pravděpodobně pochází z ruderální nebo aluviální vegetace. Sbírány mohly být také dubové žaludy. Byl však identifikován pouze jeden kus žaludu dubu obecného (Quercus cf. robur).

\subsection{Krajina a vegetace ve starém neolitu}

Druhová spektra zjištěná archeobotanickou analýzou pokrývají řadu přírodních stanovišt a typů vegetace. Přítomnost vodních druhů jako je Potamogeton sp., Batrachium sp. a zelené řasy Chara sp. a Nitella sp. dokazuje vodní stanoviště přímo ve studni, což se zdá být překvapivé vzhledem $\mathrm{k}$ její velikosti. Pro výskyt těchto rostlin však postačuje dočasné vysušení. Důkazy o jejich výskytu jsou známy také $\mathrm{z}$ jiných neolitických studní v Německu (Herbig et al. 2012/2013).

V okolí studny byly prokázány pastviny, okraje polí nebo jiná stepní stanoviště. Uničovská studna byla záměrně zaplněna, což vedlo $\mathrm{k}$ výskytu rostlin spojených s mokrými a narušenými stanovišti, jako je Chenopodium album a Atriplex sp. Ruderální vegetace byla zastoupena druhy jako Polygonum aviculare a Plantago major, které se běžně vyskytují na pošlapávaných stanovištích. Tyto rostliny představují přechod mezi přirozenými otevřenými stanovišti a později ruderálními komunitami striktně vázanými na lidské osídlení. S tím souvisí také přítomností brouků žijících na ruderálních stanovištích s nitrofilní vegetací. Kromě toho ve výplni studny převládá mikrofauna otevřených stanovišt (např. Cricetus, Microtus, Crocidura a Mustela), která je bezpochyby spojena s výskytem sekundárních stepí, jako jsou pole. Osídlené oblasti LBK byly enklávami v otevřených lesích, křovinných porostech a travnatých 
plochách (Kočár - Pokorná - Sádlo 2018), jak bylo prokázáno např. v Těšeticích-Kyjovicích (Vostrovská et al. 2019).

Třetím identifikovaným stanovištěm byl les s otevřeným zápojem a s keři na okrajích. Asi 48,9 \% lísky (Corylus) bylo detekováno v antrakologických záznamech ze všech prozkoumaných LBK studní v Česku. Vyšší hojnost Corylus může naznačovat lidský vliv na okolní lesy, kde líska jako pionýrská dřevina nahradila dříve dominantní Quercus. Corylus vykazuje vyšší hojnost také v pylovém záznamu ve studni. O vlivu prvních zemědělců na okolní vegetaci se diskutuje (Willis - Bennett 1994). Některé analýzy předpokládají změny ve složení lesů (Magyari et al. 2012), ale regionální studie neukazují žádné změny ve složení vegetace v období LBK (Petr et al. 2013; Jamrichová et al. 2017). Vliv člověka na vegetaci je patrný v pozdním neolitu, a to pouze v lokálním měřítku (Šolcová et al. 2018).

Analýza dřeva $z$ konstrukce studny odhalila přítomnost dubů různého věku. Jejich rozdílný věk a průměr může odrážet dynamiku a prostorové členění lesa. Mozaiková struktura okolního lesa může být tvořena existencí starých dubů, představujících jádra zalesněných oblastí, a mladých dubů a lísek, které lemovaly okraje lesních oblastí. Některé druhy podčeledi Pomoideae byly také součástí okrajů lesních porostů s otevřeným zápojem. Tato struktura vegetace (Petr et al. 2013; Kuneš et al. 2015; Šolcová et al. 2018) umožňuje výskyt lehce náročných druhů a nepřítomnost typických lesních druhů závislých na uzavřeném zápoji.

Posledním zaznamenaným stanovištěm byla blízká niva, která měla jiný charakter než dnes. Toto prostředí bylo charakterizováno otevřeným břehem se štěrkopískovými lavicemi, o čemž svědčí nálezy brouků (Carabidae). Tenké dubové kmeny se širšími letokruhy pravděpodobně pocházely $z$ nivy, jejíž vlhké klima bylo příznivé pro rychlejší růst. Niva je také doložena makrozbytky kvetoucích druhů Myosoton aquaticum, Stellaria cf. neglecta a typických druhů olšových lesů Lycopus europaeus, Mentha cf. aquatica, Persicaria lapathifolia agg., Scutellaria galericulata a Sium cf. latifolium. Zajímavým nálezem je Urtica kioviensis, která je vázána na lužní lesy. Ilustruje změny v nivě během holocénního období, kdy sedimentace vytvořila $v$ nivě náplavy a štěrkopískové lavice.

Klima období LBK bylo rekonstruováno se stejnou roční průměrnou teplotou jako dnes, ale s mírnějšími zimami a nižšími srážkami. To vedlo $\mathrm{k}$ vyššímu odpařování a rostoucímu stresu ze sucha (Dabkowski et al. 2019). Takové klima odpovídá druhům rostlin spojeným s listnatými lesy, zejména jejich bylinným podrostem. Samotný hmyz ani výskyt požerků, např. tesaříků (Cerambycidae) a dřevokazů (Xyloterus sp.), na dřevech z konstrukce uničovské studny nemohou poskytnout další nezávislé důkazy týkající se klimatu. Naopak u $27 \%$ dřev z německých studen byly zjištěny požerky teplomilného tesaříka obrovského (Cerambyx cerdo L.; Tegel et al. 2012).

\section{Závěr}

Stavba neolitické studny z Uničova a její následné používání prokazatelně sahá do mladšího stupně LBK. Vnitřní konstrukce uničovské studny se skládala ze čtyř dubových rohových kůlů s podélnými drážkami, do kterých byly vodorovně zasunuty dubové desky. Srovnatelné typy konstrukcí byly zatím známy pouze $z$ doby bronzové, římské a ze středověku. Výplň studny byla na začátku tvořena rychlý procesem, který souvisel s jejím používáním. Poté, co byla porušena a opravena, byla studna používána déle. V následující fázi se prostředí studny alespoň jednou změnilo, když hladina podzemní vody klesla a následně se zase zvedla. Nakonec byla studna úmyslně zaplněna materiálem částečně sestávajícím $z$ organického odpadu.

Výplň studny poskytla velké množství kultivovaných plodin, plevelů a keřů, jakož i bohaté spektrum bylin. Výsledky archeobotanické analýzy doložily širokou škálu přírodních stanovišt a typů vegetace: vodní hladinu prímo ve studni, odpadové plochy, okraje polí nebo jiných stepních stanovišt, les s otevřeným zápojem, jehož okraje lemují keře, a nedalekou nivu. Sídelní areál prvních zemědělců v Uničově byl enklávou mezi otevřenými lesy, křovinami a travnatými plochami. Prostředí lokality můžeme rekonstruovat jako zemědělskou osadu v mozaikovité krajině zalesněných a bezlesých oblastí, jako jsou xerotermní pastviny a řeka v okolí. Naše paleoekologická rekonstrukce má pouze lokální význam, ale obecný ekologický vztah mezi environmentálními daty může významně přispět k poznání prostředí, v němž žili první zemědělci ve střední Evropě.

\section{Bibliography}

Anderberg, A.-L. 1994:

Atlas of seeds and small fruits of Northwest-European plant species (Sweden, Norway, Denmark, East Fennoscandia and Iceland) with morphological descriptions. Part 4: ResedaceaeUmbelliferae. Stockholm: Swedish Museum of Natural History.

Anděra, M. - Horáček, I. 1982:

Poznáváme naše savce. Praha: Mladá fronta.

Arnold, B. 2003:

Haches en pierre, en bronze et en fer: abattage expérimental de gros chênes destinés, en particulier, à la construction des pirogues. Archäologie der Schweiz 26/4, 43-45.

Baillie, M. G. L. - Pilcher, J. R. 1973:

A simple crossdating program for tree-ring research. Tree-Ring Bulletin 33, 7-14.

Bánffy, E. - Oross, K. 2010:

The earliest and earlier phase of the LBK in Transdanubia. In: Gronenborn, D. - Petrasch, J. /eds./: Die Neolithisierung Mitteleuropas. The spread of the Neolithic to Central Europe. Mainz: Verlag des Römisch-Germanischen Zentralmuseums, 255-272.

Barker, G. 2011:

The cost of cultivation. Nature 473, 163-164.

Beijerinck, W. 1947:

Zadenatlas der Nederlandsche flora: ten behoeve van de botanie, palaeontologie, bodemcultuur en warenkennis. Wageningen: Veenman \& Zonen.

Berggren, G. 1981:

Atlas of seeds and small fruits of Northwest-European plant species (Sweden, Norway, Denmark, East Fennoscandia and Iceland) with morphological descriptions. Part 3: SalicaceaeCruciferae. Stockholm: Swedish Museum of Natural History.

Beug, H.-J. 2004:

Leitfaden der Pollenbestimmung für Mitteleuropa und angrenzende Gebiete. München: Verlag Dr. Friedrich Pfeil.

Bogaard, A. 2004:

Neolithic Farming in Central Europe. An archaeobotanical study of crop husbandry practices. London - New York: Routledge.

Bogaard, A. 2005:

'Garden Agriculture' and the Nature of Early Farming in Europe and the Near East. World Archaeology 37/2, 177-196. DOI: $10.2307 / 40024228$.

Böhm, K. - Pleyer, R. 1990:

Geschliffene Geräte aus Felsgestein des älteren und mittleren Neolithikums aus Altbayern: Herstellung, Schäftung, praktische Anwendung. In: Fansa, M. /ed./: Experimentelle Archäologie in Deutschland. Archäologische Mitteilungen aus Nordwestdeutschland 4. Oldenburg: Isensee, 257-262.

Bronk Ramsey, C. 2017:

OxCal 4.3 Manual. Online document available at

http://c14.arch.ox.ac.uk/oxcalhelp/hlp_contents.html. Retrieved August 29/2017.

Bullock et al. 1985:

Bullock, P. - Fedoroff, N. - Jongerius, A. - Stoops, G. - Tursina, T. - Babel, T:

Handbook for soil thin section description. Wolverhampton: Waine Research Publications. 
Cappers, R. T. J. - Bekker, R. M. - Jans, J. E. A. 2006:

Digitale Zadenatlas van Nederland / Digital Seed Atlas of the Netherlands. Groningen: Barkhuis Publishing.

Chlup, T. 2017:

Záchranný archeologický výzkum neolitického sídliště ve Velimi (okr. Kolín) v roce 2016. Předběžná zpráva — The rescue excavation at the Neolithic site of Velim, Kolín District, in 2016. A preliminary report. Archeologie ve Středních Čechách 21 , 63-72.

Chlup et al. in preparation:

Chlup, T. - Kolář, T. - Rybníček, M. - Petr, L. - Horsák, M. Kočár, P. - Kyncl, T. - Limburský, P. - Muigg, B. - Tegel, W. Sůvová, Z. - Škrdlantová, M. - Drábková, K. - Bureš Víchová, J.: Studna kultury s lineární keramikou z Velimi.

Choulot et al. 1997:

Choulot, S. - Ernst, T. - Joly, F. - Maréchal, D. - Monnier, J.-L. Weller, O. - Pétrequin, P.:

L'abattage et le façonnage des bois d'œvre. In: Pétrequin, P. /ed./: Les sites littoraux néolithiques de Clairvaux-les-Lacs et de Chalain (Jura) III, Chalain Station 3, 3200-2900 av. J.-C. Paris: Editions de la Maison des Sciences de l'Homme, 187-210.

Chytrý, M. 2012:

Vegetation of the Czech Republic: diversity, ecology, history and dynamics. Preslia 84, 427-504.

Culek et al. 2005:

Culek, M. /ed./ - Buček, A. - Grulich, V. - Hartl, P. - Hrabica, A. - Kocián, J. - Kyjouský, Š.:

Biogeografické členění České republiky, II. díl. Praha: Agentura ochrany přírody a krajiny České republiky.

Červený, Č. - Komárek, V. - Štěrba, O. 1999:

Koldův atlas veterinární anatomie. Praha: Grada.

Dabkowski et al. 2019:

Dabkowski, J. - Frodlová, J. - Hájek, M. - Hájková, P. - Petr, L. - Fiorillo, D. - Dudová, L. - Horsák, M.

A complete Holocene climate and environment record for the Western Carpathians (Slovakia) derived from a tufa deposit. The Holocene 29/3, 493-504.

DOI: $10.1177 / 0959683618816443$.

Divíšek et al. 2020:

Divíšek, J. - Hájek, M. - Jamrichová, E. - Petr, L. - Večeřa, M. Tichý, L. - Willner, W. -Horsák, M.:

Holocene matters: Landscape history accounts for current species richness of vascular plants in forests and grasslands of eastern Central Europe. Journal of Biogeography 47/3, 721-735. DOI: $10.1111 /$ jbi.13787.

Dobrovolný et al. 2016:

Dobrovolný, P. - Rybníček, M. - Büntgen, U. - Trnka, M. Brázdil, R. - Stachoň, Z. - Prokop, O. - Kolár̆, T.:

Recent growth coherence in long-term oak (Quercus spp.) ring width chronologies in the Czech Republic. Climate Research 70, 133-141. DOI: 10.3354/cr01402.

Dreslerová, D. 2012:

Les v pravěké krajině II - Forest in the prehistoric landscape II. Archeologické rozhledy 64, 199-236.

Dreslerová, D. - Kočár, P. 2013

Trends in cereal cultivation in the Czech Republic from the Neolithic to the Migration period (5500 B.C.-A.D. 580). Vegetation History and Archaeobotany 22/3, 257-268.

DOI: $10.1007 / \mathrm{s} 00334-012-0377-8$.

Dreslerová, D. - Sádlo, J. 2000:

Les jako součást pravěké kulturní krajiny — The Forest as a Component of the Prehistoric Cultural Landscape. Archeologické rozhledy 52, 330-346.
Dudová et al. 2018:

Dudová, L. - Hájek, M. - Petr, L. - Jankovská, V.:

Holocene vegetation history of the Jeseníky Mts: Deepening elevational contrast in pollen assemblages since late prehistory. Journal of Vegetation Science 29, 371-381.

DOI: $10.1111 /$ jvs. 12612 .

Eckstein, D. - Bauch, J. 1969:

Beitrag zur Rationalisierung eines dendrochronologischen Verfahrens und zur Analyse seiner Aussagesicherheit. Forstwissenschaftliches Centralblatt 88, 230-250.

DOI: $10.1007 / \mathrm{BF} 02741777$.

Einicke, R. 1998:

Zwei Altfunde bandkeramischer Brunnen aus Mitteldeutschland. In: Koschik, H. /ed./: Brunnen der Jungsteinzeit. Internationales Symposium in Erkelenz, 27. bis 29. Oktober 1997. Materialen zur Bodendenkmalpflege im Rheinland 11. Köln: Rheinland-Verlag GmbH, 73-84.

Elburg, R. 2008:

Eine Dechselklinge mit Schäftungsresten aus dem bandkeramischen Brunnen von Altscherbitz. Arbeits- und Forschungsberichte zur sächsischen Bodendenkmalpflege 50, 9-15.

Elburg et al. 2015:

Elburg, R. - Hein, W. - Probst, A. - Walter, P. 2015:

Field Trials in Neolithic Woodworking - (Re)Learning to Use Early Neolithic Stone Adzes. Experimental Archaeology Journal 2015/2. Online document available at https://exarc.net/ark:/88735/10196.

Elburg, R. - Herold, P. 2010:

Tiefe Einblicke in die Vergangenheit. Der jungsteinzeitliche Brunnen aus Altscherbitz gibt Aufschluss über das Leben vor 7100 Jahren. Archaeo 7, 23-27.

Friederich, S. 2017:

Der linien-bandkeramische Brunnen von Leipzig-Plaußig. Mit Beiträgen von Henriette Baron, Michael Friedrich, Dietrich Hakelberg, Ursula Maier, Manfred Rösch, Edith Schmidt, Harald Stäuble und Christian Tinapp. Veröffentlichungen des Landesamtes für Archäologie Sachsen 62. Dresden: Landesamt für Archäologie Sachsen.

Friedrich, M. 2017:

Dendrochronologische Untersuchungen der Hölzer aus drei linienbandkeramischen Brunnen bei Leipzig. In: Friederich, S. /ed./: Der linienbandkeramische Brunnen von Leipzig-Plaußig. Veröffentlichungen des Landesamtes für Archäologie Sachsen 62. Dresden: Landesamt für Archäologie Sachsen, 421-440.

Fülöp et al. 2018:

Fülöp, K. - Lönhardt, D. M. - Szabó, N. - Váczi, G.:

Preliminary report on the excavation of the site TiszakürtZsilke-tanya. Dissertationes Archaeologicae ex Instituto Archaeologico Universitatis de Rolando Eötvös nominatae 3/6, 499-514.

Füzesi et al. 2015:

Füzesi, A. - Bartus, D. - Fülöp, K. - Juhász, L. - Rupnik, L. Siklósi, Z. - Szabó, G. V. - Szilágyi, M. - Váczi, G.:

Preliminary report on the field surveys and excavations in the vicinity of Berettyóújfalu. Dissertationes Archaeologicae ex Instituto Archaeologico Universitatis de Rolando Eötvös nominatae 3/3, 223-239.

Garfinkel, Y. - Vered, A. - Bar-Yosef, O. 2006:

The domestication of water: the Neolithic well at Sha'ar Hagolan, Jordan Valley, Israel. Antiquity 80, 686-696.

DOI: 10.1017/S0003598X00094138.

Gebel, H. G. K. 2004:

The Domestication of Water. Evidence from Early Neolithic Ba’ja? In: Bienert, H.-D. - Häser, J. /eds./: Men of Dikes and 
Canals. The Archaeology of Water in the Middle East. International Symposium held at Petra, Wadi Musa (H. K. of Jordan) 15-20 June, 1999. Orient-Archäologie 13. Rahden/Westfalen: Verlag Marie Leidorf GmbH, 25-35.

Gollnisch-Moos, H. 1999:

Ürschhausen-Horn: Haus- und Siedlungsstrukturen der spätestbronzezeitlichen Siedlung (Archäologie im Thurgau). Thurgau: Departement für Erziehung und Kultur.

Green, A. J. - Figuerola, J. - Sánchez, M. I. 2002:

Implications of waterbird ecology for the dispersal of aquatic organisms. Acta Oecologia 23, 177-189.

Grosser, D. 2007:

Die Hölzer Mitteleuropas. Ein mikrophotographischer Lehratlas. Reprint der 1. Auflage von 1977. Remagen: Verlag Kessel.

Hachem, L. 2018:

Animals in LBK society: Identity and gender markers. Journal of Archaeological Science: Reports 20, 910-921.

DOI: 10.1016/j.jasrep.2017.09.020.

Hadač, E. - Hašek, M. 1949:

Remmants of Wood from the Prehistoric Fire Places in Bohemia. Studia Botanica Čechoslovaca, 135-148.

Hajnalová, M. 2011:

Rastlinné makrozvyšky. In: Březinová, G. - Pažinová, N. /eds./: Neolitická osada Hurbanovo - Bohatá. Archaeologica Slovaca Monographiae. Catalogi 13. Nitra: Archeologický ústav SAV Nitra, 142-187.

Hajnalová, M. 2012:

Archeobotanika doby bronzovej na Slovensku. Štúdie ku klíme, prírodnému prostrediu, polnohospodárstvu a paleoekonómii - The Archaeobotany of Bronze Age in Slovakia. Studies on climate, the natural environment, agriculture and paleoeconomics. Nitra: Filozofická fakulta Univerzity Konštantína Filozofa v Nitre.

\section{Hajnalová et al. 2018:}

Hajnalová, M. - Bielichová, Z. - Rajtár, J. - Krčová, D. - Čejka, T. - Šustek, Z. - Mihályiová, J.:

A Roman Structure from Hurbanovo, SW Slovakia: Multiproxy Investigation of Unique Waterlogged Deposit. Interdisciplinaria Archaeologica - Natural Sciences in Archaeology 9/1, 43-69. DOI: 10.24916/iansa.2018.1.4.

Heiri, O. - Lotter, A. F. - Lemcke, G. 2001:

Loss on ignition as a method for estimating organic and carbonate content in sediments: reproducibility and comparability of results. Journal of Paleolimnology 25, 101-110.

\section{Hellqvist, M. 1999:}

Insect assemblages from iron age wells in central Sweden. Norwegian Archaeological Review 32, 1-17.

DOI: $10.1080 / 002936599420876$.

Herbig et al. 2012/2013:

Herbig, C. - Maier, U. - Stäuble, H. - Elburg, R.:

"Neolithische Füllhörner". Archäobotanische Untersuchungen an fünf linienbandkeramischen Brunnen in Westsachsen. Offa 69/70, 265-293.

Hillman, G. C. 1981:

Reconstructing crop husbandry practices from charred remains of crops. In: Mercer, R. J. /ed./: Farming Practice in British Prehistory. Edinburgh: Edinburgh University Press, 123-162.

Hollstein, E. 1980:

Mitteleuropäische Eichenchronologie. Triererdendrochronologische Forschungen zur Archäologie und Kunstgeschichte. Mainz am Rhein: Trierer Grabungen und Forschungen.
Horáček, I. - Ložek, V. 1988:

Paleozoology and the Mid-European Quaternary past: scope of the approach and selected results. Rozpravy Československé akademie věd, řada matematických a přírodních věd 98/4.

Husmann, H. - Cziesla, E. 2014:

Bandkeramische Häuser, Brunnnen und ein Erdwerk. In: Cziesla, E. - Ibeling, T. /eds./: Autobahn 4. Fundplatz der Extraklasse. Archäologie unter der neuen Bundesautobahn bei Arnoldsweiler. Langenweissbach: Beier \& Beran, 71-118.

Jacomet, S. 2006:

Identification of Cereal Remains from Archaeological Sites. $2^{\text {nd }}$ edition. Basel: Institute for Prehistory and Archaeological Science.

Jamrichová et al. 2017:

Jamrichová, E. - Petr, L. - Jiménez-Alfaro, B. - Jankouská, V. - Dudová, L. - Pokorný, P. - Kotaczek, P. - Zernitskaya, V. Čierniková, M. - Břizová, E. - Syrovátka, V. - Hájková, P. Hájek, M.:

Pollen-inferred millennial changes in landscape patterns at a major biogeographical interface within Europe. Journal of Biogeography 44/10, 2386-2397. DOI: 10.1111/jbi.13038.

Jones, G. 1984:

Interpretation of archaeological plant remains: ethnographic models from Greece. In: van Zeist, W. - Casparie, W. A. /eds./: Plants and ancient man. Studies in palaeoethnobotany: proceedings of the Sixth Symposium of the International Work Group for Palaeoethnobotany, Groningen, 30 May - 3 June 1983. Rotterdam: A. A. Balkema, 43-61.

\section{Kalábek, M. 2016:}

Uničov (okr. Olomouc). „U kravína“. Kultura s lineární keramikou. Sídliště. Záchranný archeologický výzkum. Přehled výzkumů 57/1, 178-180.

Király, Á. - Tóth, K. 2015:

Preliminary Report on the Middle Neolithic Well from Sajószentpéter (North-Eastern Hungary). Dissertationes Archaeologicae ex Instituto Archaeologico Universitatis de Rolando Eötvös nominatae 3/3, 213-221.

\section{Knörzer, K.-H. 1998:}

Botanische Untersuchungen am bandkeramischen Brunnen von Erkelenz-Kückhoven. In: Koschik, H. /ed./: Brunnen der Jungsteinzeit. Internationales Symposium in Erkelenz, 27. bis 29. Oktober 1997. Materialen zur Bodendenkmalpflege im Rheinland 11. Köln: Rheinland-Verlag GmbH, 229-246.

Kočár et al. 2007:

Kočár, P. - Sưvová, Z. - Kočárová, R. - Kyncl, T:

Environmental analysis of the content of Renaissance cesspit from Malá Strana in Prague. Studies in Post-Mediaeval Archaeology 2, 383-400.

Kočár, P. - Pokorná, A. - Sádlo, J. 2018:

Změny synantropní vegetace na území České republiky v zemědělském pravěku a raném středověku - Changes in synanthropic vegetation of the Czech Republic in Prehistoric times and Early Middle Ages (5600 BC - AD 1200). Zprávy České botanické společnosti 53/2, 217-238.

Kočár, P. - Šumberová, R. - Kočárová, R. 2014:

Antrakotomický soubor $z$ neolitického sídliště u Kolína. Příspěvek (nejen) k rekonstrukci lesní vegetace v neolitu České Republiky - An anthracological assemblage from the Neolithic settlement near Kolín. On the reconstruction of forest vegetation in the Neolithic period in the territory of the Czech Republic, and related issues. Archeologické rozhledy 66, 391-414. Koschik, H. /ed./ 1998:

Brunnen der Jungsteinzeit. Internationales Symposium in Erkelenz, 27. bis 29. Oktober 1997. Materialen zur Bodendenkmalpflege im Rheinland 11. Köln: Rheinland-Verlag GmbH. 
Kretschmer et al. 2016

Kretschmer, S. - Viol, P. - Stäuble, H. - Herbig, C. - Muigg, B. Tegel, W. - Tinapp, C.:

Der Fundplatz Droßdorf im Tegebaufeld Peres (Lkr. Leipzig). Ein früh-, mittel- und spätneolithisches Siedlungsareal mit zahlreichen Brunnen. Ausgrabungen in Sachsen 5, 30-57.

Kreuz et al. 2005:

Kreuz, A. - Marinova, E. - Schäfer, E. - Wiethold, J.:

A comparison of early Neolithic Crop and weed assemblages from the Linearbandkeramik and Bulgarian Neolithic cultures: differences and similarities. Vegetation History and Archaeobotany 14, 237-258. DOI: 10.1007/s00334-005-0080-0.

Kreuz, A. - Schäfer, E. 2011 :

Weed finds as indicators for the cultivation regime of the early Neolithic Bandkeramik culture? Vegetation History and Archaeobotany 20, 333-348. DOI: 10.1007/s00334-011-0294-2.

Kuča et al. 2012:

Kuča, M. - Kovár̆, J. J. - Nývltová Fišáková, M. - Škrdla, P. Prokeš, L. - Vaškových, M. - Schenk, Z.:

Chronologie neolitu na Moravě: předběžné výsledky - Chronology of the Moravian Neolithic: preliminary results. Přehled výzkumů 53/1, 51-64.

Kučera, J. - Ván̆a, J. - Hradílek, Z. 2012:

Bryophyte Flora of the Czech Republic: updated checklist and Red List and a brief analysis. Preslia 84, 813-850.

Kuneš et al. 2015:

Kuneš, P. - Svobodová-Svitavská, H. - Kolár̆, J. - Hajnalová, M. - Abraham, V. - Macek, M. - Tkáč, P. - Szabó, P.:

The origin of grasslands in the temperate forest zone of eastcentral Europe: long-term legacy of climate and human impact. Quaternary Science Reviews 116, 15-27.

DOI: $10.1016 /$ j.quascirev.2015.03.014.

Kyselý, R. 2004:

Kvantifikační metody v archeozoologii - Quantification methods in archaeozoology. Archeologické rozhledy 56, 279-296.

Lenneis, E. /ed./ 2010:

Die bandkeramische Siedlung von Mold bei Horn in Niederösterreich. Teil I: Naturwissenschaftliche Beiträge und Einzelanalysen. Internationale Archäologie 115. Rahden/Westfalen: Verlag Marie Leidorf GmbH.

Lobisser, W. F. A. 2005:

Zum Nachbau eines linearbandkeramischen Brunnenkastens mit Werkzeugen aus Holz, Stein und Knochen. In: Both, F. Vorlauf, D. /eds./: Von der Altsteinzeit über „Ötzi“ bis zum Mittelalter. Ausgewählte Beiträge zur Experimentellen Archäologie in Europa von 1990-2003. Experimentelle Archäologie in Europa, Sonderband 1. Oldenburg: Isensee, 241-254.

Lyman, R. L. 2008:

Quantitative Paleozoology. Cambridge - New York: Cambridge University Press.

Magyari et al. 2012:

Magyari, E. K. - Chapman J. - Fairbairn, A. S. - Francis, M. de Guzman, M.:

Neolithic human impact on the landscapes of North-East Hungary inferred from pollen and settlement records. Vegetation History and Archaeobotany 21/4-5, 279-302.

DOI: $10.1007 / \mathrm{s} 00334-012-0350-6$.

Manning et al. 2014:

Manning, K. - Timpson, A. - Colledge, S. - Crema, E. - Edinborough, K. - Kerig, T. - Shennan, S.:

The chronology of culture: a comparative assessment of European Neolithic dating approaches. Antiquity 88/342, 10651080. DOI: 10.1017/S0003598X00115327.
Meier, M. 1990

Das Arbeiten mit neolithischen Felsgesteinbeilen. In: Fansa, M. /ed./: Experimentelle Archäologie in Deutschland. Archäologische Mitteilungen aus Nordwestdeutschland 4. Oldenburg: Isensee, 273-278.

Miller, R. 1980:

Water use in Syria and Palestine from the Neolithic to the Bronze Age. World Archaeology 11/3, 331-341.

DOI: $10.1080 / 00438243.1980 .9979771$.

Mithen, S. 2010:

The domestication of water: water management in the ancient world and its prehistoric origins in the Jordan Valley. Philosophical Transactions of the Royal Society A: Mathematical, Physical and Engineering Sciences 368/1931, 5249-5274. DOI: $10.1098 /$ rsta.2010.0191.

Moore, P. D. - Webb, J. A. - Collingson, M. E. 1991:

Pollen Analysis. Oxford: Blackwell Scientific Publications.

Neustupny, E. F. - Vesely, K. 1977:

Most Radiocarbon Dates I. Radiocarbon 19/2, 183-187.

DOI: $10.1017 /$ S0033822200003520.

Novák et al. 2017:

Novák, J. - Abraham, V. - Kočár, P. - Petr, L. - Kočárová, R. Nováková, K. - Houfková, P. - Jankovská, V. - Vaněček, Z.:

Middle- and upper-Holocene woodland history in central Moravia (Czech Republic) reveals biases of pollen and anthracological analysis. The Holocene 27/3, 349-360.

DOI: $10.1177 / 0959683616660166$.

Novák, J. - Krasnokutská, T. 2009:

Analýza uhlíků ze sídliště kultury s lineární keramikou v Bravanticích, okres Nový Jičín. In: Bém, M. - Peška, J. /eds./: Ročenka 2008. Olomouc: Archeologické centrum Olomouc, 53-58.

Opravil, E. 1965 :

Zajímavý nález uhlíků z mladší doby kamenné na Opavsku. Zprávy (Arboretum Nový Dvưr u Opavy) 1, 17-18.

Opravil, E. 1972:

Vorläufiger Bericht über die Bestimmung der Holzfunde aus Mohelnice (Neolithikum, Äneolithikum), Bez. Šumperk. Přehled výzkumů 1971, 21-23.

Opravil, E. 1977:

Nález rostlinných zbytků na neolitickém sídlišti v Mohelnici. Severní Morava 23, 34-37.

Opravil, E. 1979a:

Rostlinné zbytky z Mohelnice 1 - Pflanzenreste aus Mohelnice 1. Časopis Slezského musea, série A, vědy přírodní 28/1, $1-13$.

Opravil, E. 1979b:

Rostlinné zbytky z Mohelnice 2 - Pflanzenreste aus Mohelnice (Neolithikum, Bronzezeit). Časopis Slezského musea, série A, vědy přírodní 28/2, 97-109.

Opravil, E. 1996:

Archeobotanické nálezy $z$ historického jádra Opavy z výzkumné sezony 1993-1994. Časopis Slezského musea, série A, vědy přírodní $45,1-15$.

Pavlů, I. /ed./ - Zápotocká, M. 2013:

The prehistory of Bohemia 2. The Neolithic. Praha: Archeologický ústav AV ČR, Praha, v. v. i.

Pearsall, D. M. 2001:

Paleoethnobotany. A Handbook of Procedures. San Diego London: Academic Press.

Petr, L. - Novák, J. 2014:

High vegetation and environmental diversity during the Late 
Glacial and Early Holocene on the example of lowlands in the Czech Republic. Biologia 69/7, 847-862.

DOI: $10.2478 / \mathrm{s} 11756-014-0381-9$.

Petr et al. 2013:

Petr, L. - Žáčková, P. - Grygar, T. M. - Píšková, A. - Kř̌̌žek, M. Treml, $V$ :

Š́r, a former late-glacial and Holocene lake at the westernmost margin of the Carpathians. Preslia 85, 239-263.

Pétrequin, P. - Pétrequin, A.-M. 1993:

Écologie d'un outil : la hache de pierre en Irian Jaya (Indonésie). Monographie du Centre de Recherches Archéologiques 12. Paris: CNRS Éditions.

Plarre, R. 2010:

An attempt to reconstruct the natural and cultural history of the granary weevil, Sitophilus granarius (Coleoptera: Curculionidae). European Journal of Entomology 107, 1-11. DOI: $10.14411 /$ eje.2010.001.

Pleinerová, I. 2005:

Studny z doby stěhování národů v Hostivici-Paloukách (okr. Praha-západ) - Völkerwanderungszeitliche Brunnen in Hostivice-Palouky (Bez. Prag-West). Památky archeologické 96, 105-126.

Pokorná et al. 2018:

Pokorná, A. - Kočár, P. - Novák, J. - Šálková, T. - Žáčková, P. Komárková, V. - Vaněček, Z. - Sádlo, J.:

Ancient and Early Medieval man-made habitats in the Czech Republic: colonization history and vegetation changes. Preslia 90, 171-193.

Pokorný et al. 2015:

Pokorný, P. - Chytrý, M. - Juřičková, L. - Sádlo, J. - Novák, J. Ložek, $V$ :

Mid-Holocene bottleneck for central European dry grasslands: Did steppe survive the forest optimum in northern Bohemia,

Czech Republic? The Holocene 25/4, 716-726.

DOI: $10.1177 / 0959683614566218$.

Price, D. T. 2000:

Europe's first farmers: an introduction. In: Price, D. T. /ed./: Europe's first farmers. Cambridge: Cambridge University Press, 1-18. DOI: 10.1017/CBO9780511607851.

Prokop et al. 2017:

Prokop, O. - Kolář, T. - Kyncl, T. - Rybníček, M.:

Updating the Czech millennia-long oak tree-ring width chronology. Tree-ring research 73/1, 47-52.

DOI: $10.3959 / 1536-1098-73.1 .47$.

Přichystal, M. 2008:

Brno (k. ú. Bohunice, Nový a Starý Lískovec, okr. Brno-město). Přehled výzkumů 49/1, 271-272.

Pyšek et al. 2012:

Pyšek, P. - Danihelka, J. - Sádlo, J. - Chrtek Jr., J. - Chytrý, M. Jarošík, V. - Kaplan, Z. - Krahulec, F. - Moravcová, L. - Pergl, J. - Štajerová, K. - Tichý, L.:

Catalogue of alien plants of the Czech Republic ( $2^{\text {nd }}$ edition): checklist update, taxonomic diversity and invasion patterns Nepůvodní flóra České republiky: aktualizace seznamu druhů, taxonomická diverzita a průběh invazí. Preslia 84, 155-255.

Rageth, J. 1986:

Die wichtigsten Resultate der Ausgrabungen in der bronzezeitlichen Siedlung auf dem Padnal bei Savognin (Oberhalbstein GR). Jahrbuch der Schweizerischen Gesellschaft für Ur- und Frühgeschichte 69, 62-103.

Reimer a kol. 2013:

Reimer, P. J. - Bard, E. - Bayliss, A. - Beck, J. W. - Blackwell, P. G. - Brok Ramsey, Ch. - Buck, C. E. - Cheng, H. - Edwards, R. L. - Friedrich, M. - Grootes, P. M. - Guilderson, T. P. -
Haflidason, H. - Hajdas, I. - Hatté, Ch. - Heaton, T. J. Hoffmann, D. L. - Hogg, A. G. - Hughen, K. A. - Kaiser, K. F. Kromer, B. - Manning, S. W. - Niu, M. - Reimer, R. W. - Richards, D. A. - Scott, E. M. - Southon, J. R. - Staff, R. A. - Turney, Ch. S. M. - van der Plicht, J.:

IntCal13 and Marine13 Radiocarbon Age Calibration Curves 0-50,000 Years cal BP. Radiocarbon 55/4, 1869-1887.

DOI: $10.2458 /$ azu_js_rc.55.16947.

Reitz, E. J. - Wing, E. S. 2008:

Zooarchaeology. Cambridge: Cambridge University Press. $2^{\text {nd }}$ edition.

Rösch, M. 2017:

Moosfunde aus drei linienbandkeramischen Brunnen in Sachsen (Leipzig-Plaußig, Eythra Brunnen 1 und 2). In: Friederich, S. /ed./: Der linienbandkeramische Brunnen von LeipzigPlaußig. Veröffentlichungen des Landesamtes für Archäologie Sachsen 62. Dresden: Landesamt für Archäologie Sachsen, 401-419.

Rulf, J. - Velímský, T. 1993:

A Neolithic well from Most. Archeologické rozhledy 45, 545-560.

Rybníček et al. 2018:

Rybníček, M. - Chlup, T. - Kalábek, M. - Kalábková, P. - Kočár, P. - Kyncl, T. - Muigg, B. - Tegel, W. - Vostrouská, I. - Kolár̆, T.: New dendroarchaeological evidence of water well constructions reveals advanced Early Neolithic craftman skills. Dendrochronologia 50, 98-104.

DOI: $10.1016 /$ j.dendro.2018.06.003.

Rybníček et al. 2020:

Rybníček, M. - Kočár, P. - Muigg, B. - Peška, J. - Sedláček, R. Tegel, W. - Kolár̆, T:

World's oldest dendrochronologically dated archaeological wood construction. Journal of Archaeological Science 115, 105082. DOI: $10.1016 /$ j.jas.2020.105082.

Salavert, A. 2011 :

Plant economy of the first farmers of central Belgium (Linearbandkeramik, 5200-5000 B.C.). Vegetation History and Archaeobotany 20, 321-332. DOI: 10.1007/s00334-011-0297-z.

Schell, F. - Herbig, Ch. 2018:

Ein linienbandkeramischer Brunnen im Labor. Die Ausgrabungen einer Blockbergung (Bef. 3682) aus Droßdorf (LKr. Leipzig). Ausgrabungen in Sachsen 6, 16-36.

Schmid, E. 1972:

Atlas of Animal Bones: For Prehistorians, Archaeologists and Quaternary Geologists. Amsterdam: Elsevier.

Schmidt, E. 1998:

Der Kornkäfer Sitophilus granarius Schoen. Curculionidae aus der Schuttschicht des bandkeramischen Brunnens von Erkelenz-Kückhoven. In: Koschik, H. /ed./: Brunnen der Jungsteinzeit. Internationales Symposium in Erkelenz 27. bis 29. Oktober 1997. Materialen zur Bodendenkmalpflege im Rheinland 11. Köln: Rheinland-Verlag GmbH, 261-269.

Schmidt, E. 2017:

Die Insektenreste aus der linienbadkeramischen Brunnenanlage Leipzig-Plaußig. In: Friederich, S. /ed./: Der linienbandkeramische Brunnen von Leipzig-Plaußig. Veröffentlichungen des Landesamtes für Archäologie Sachsen 62. Dresden: Landesamt für Archäologie Sachsen, 285-345.

Schmidt, B. - Gruhle, W. 2003:

Wuchshomogenität als ein neues Analyseverfahren zur Verbesserung der dendrochronologischen Datierungsmethode. Die Hölzer der neolithischen Brunnen von Erkelenz-Kückhoven, Zwenkau und Mohelnice sowie vom Fundplatz Kaster. In: Eckert, J. - Eisenhauer, U. - Zimmermann, A. /eds. /: Archäologische Perspektiven. Analyse und Interpretationen im Wan- 
del. Festschrift für Jens Lüning zum 65. Geburtstag. Rahden/ Westfalen: Verlag Marie Leidorf GmbH, 49-59.

Schoch et al. 2004:

Schoch, W. - Heller, I. - Schweingruber, F. H. - Kienast, F. 2004: Wood anatomy of central European Species. Online version: http:www.woodanatomy.ch. Last access: October 20, 2019.

Schweingruber, F. H. 1990a:

Anatomie europäischer Hölzer. Ein Atlas zur Bestimmung europäischer Baum-, Strauch- und Zwergstrauchhölzer. Bern Stuttgart: Verlag Paul Haupt.

Schweingruber, F. H. 1990b:

Mikroskopische Holzanatomie. Formenspektren mitteleuropäischer Stamm- und Zweighölzer zur Bestimmung von rezentem und subfossilem Material (3. Auflage). Birmensdorf: Eidgenössische Forschungsanstalt für Wald, Schnee und Landschaft.

Sedláček et al. 2008:

Sedláček, R. - Beneš, J. - Čejková, A. - Kolářr, T. - Komárková, V. - Kyncl, T. - Novák, J. - Nováková, K. - Světlík, I.:

Studna $\mathrm{z}$ doby římské $\mathrm{z}$ Dražkovic u Pardubic: komplexní archeologická a archeobotanická analýza / The well from Dražkovice by Pardubice: a complex archaeological and archaeobotanical analysis. In: Beneš, J. - Pokorný, P. /eds./: Bioarcheologie v České republice / Bioarchaeology in the Czech Republic. Praha: Jihočeská univerzita v Českých Budějovicích, Přírodovědecká fakulta - Archeologický ústav AV ČR, Praha, v. v. i., 285-330.

Sedláček et al. 2019:

Sedláček, R. - Kočár, P. - Rybníček, M. - Kočárová, R. - Petr, L. - Horsák, M. - Vychronová, M. - Sůvová, Z. - Peška, J.:

Nejstarší dendrochronologicky datovaná dřevěná konstrukce v Evropě: neolitická studna na katastru Ostrova - první výsledky výzkumu. In: Nerudová, Z. /ed./: Sborník abstraktů 15. Konference environmentální archeologie: „Historie nezná kdyby“. Brno: Moravské zemské muzeum, 37-38.

Stäuble, H. 2018:

Brunnen gehören zur Kultur der Linienbandkeramik. In: Wemhoff, M. - Rind, M. M. /eds./: Bewegte Zeiten: Archäologie in Deutschland. Katalog aus der Ausstellung (vom 21. September 2018 bis 6. Januar 2019 im Martin-Gropius-Bau Berlin). Berlin: Michael Imhof Verlag, 78-81.

Stäuble, H. - Campen, I. 1998:

7000 Jahre Brunnenbau im Südraum von Leipzig-Brunnen der Jungsteinzeit. In: Koschik, H. /ed./: Brunnen der Jungsteinzeit. Internationales Symposium in Erkelenz, 27. bis 29. Oktober 1997. Materialen zur Bodendenkmalpflege im Rheinland 11. Köln: Rheinland-Verlag GmbH, 51-71.

Stäuble, H. - Veit, U. /eds./ 2016:

Der bandkeramische Siedlungsplatz Eythra in Sachsen. Studien zur Chronologie und Siedlungsentwicklung. Leipziger Forschungen zur Ur- und Frühgeschichtlichen Archäologie 9. Leipzig: Professur für Ur- und Frühgeschichte der Universität Leipzig.

Stoops, G. 2003:

Guidelines for Analysis and Description of Soil and Regolith Thin Sections. Madison - Wisconsin: Soil Science Society of America.

Stoops, G. - Eswaran, H. 1986:

Soil micromorphology. New York: Van Nostrand Reinhold Company Inc.

Šolcová et al. 2018:

Šolcová, A. - Petr, L. - Hájková, P. - Petř́ík, J. - Tóth, P. - Rohovec, J. - Bátora, J. - Horsák, M.:

Early and middle Holocene ecosystem changes at the Western Carpathian/Pannonian border driven by climate and Neolithic impact. Boreas 47/3, 897-909. DOI: 10.1111/bor.12309.
Talon, B. - Carcaillet, C. - Thinon, M. 1998:

Études pédoanthracologiques des variations de la limite supérieure des arbres au cours de l'Holocène dans les Alpes françaises. Géographie physique et Quaternaire 52, 195-208. DOI: 10.7202/004875ar.

Tegel et al. 2012:

Tegel, W. - Elburg, R. - Hakelberg, D. - Stäuble, H. - Büntgen, U.: Early Neolithic Water Wells Reveal the World's Oldest Wood Architecture. PloS ONE 7/12, e51374

DOI: $10.1371 /$ journal.pone.0051374.

Tichý, R. 1972:

XIII. Grabungssaison in Mohelnice (Bez. Šumperk). Přehled výzkumů 16 (1971), 17-21, 153-163.

Tinapp, C. - Schneider, B. - Stäuble, H. 2013:

Geochemical analysis of the sediments in and around an Early Neolithic well near Brodau, Germany. Archaeometry 55/3, 533-544. DOI: 10.1111/j.1475-4754.2012.00700.x.

Tolksdorf et al. 2017:

Tolksdorf, J. F. - Schmalfuß, G. - Herbig, C. - Köster, H. Turner, F. - Stäuble, H.:

End Neolithic Water Management in Central Germany Based on Geoarchaeological and Palaeobotanical Analyses of Wells at the Roitzschjora site, Northern Saxony. Journal of Neolithic Archaeology 19, 127-140. DOI: 10.12766/jna.2017.5.

Vostrouská et al. 2019:

Vostrovská, I. - Bíšková, J. - Lukšíková, H. - Kočár, P. - Kočárová, $R$ :

The Environment and Subsistence of the Early Neolithic Settlement Area at Těšetice-Kyjovice, Czech Republic. Environmental Archaeology: The Journal of Human Palaeoecology 24/3, 248-262. DOI: 10.1080/14614103.2018.1424981.

Walanus, A. - Nalepka, D. 1999:

POLPAL. Program for Counting Pollen Grains, Diagrams Plotting and Numerical Analysis. Acta Palaeobotanica - Supplementa 2, 659-661.

Weiner, J. 1992a:

Feuchtbodenfunde ohne Moor und Seeufer - Zwei Spaten aus dem bandkeramischen Brunnen von Erkelenz-Kückhoven. Archäologische Mitteilungen Aus Nordwestdeutschland 15, 161-166.

Weiner, J. 1992b:

Der früheste Nachweis der Blockbauweise. Zum Stand der Ausgrabung des bandkeramischen Holzbrunnens. Archäologie im Rheinland 1991, 30-33.

Weiner, J. 1994:

Well on my back - An update on the Bandkeramik wooden well of Erkelenz-Kückhoven. NewsWARP 16, 5-17.

Weiner, J. 1995:

Zum Abschluß der Ausgrabung des bandkeramischen Brunnens in Kückhoven. Archäologie im Rheinland 1994, 21-25.

Weiner, J. 1997:

A Bandkeramik Settlement with Wooden Well from ErkelenzKückhoven, Northrine-Westphalia (FRG). In: Jeunesse, C. /ed./: Le Néolithique danubien et ses marges entre Rhin et Seine. Actes du XXII ${ }^{\mathrm{e}}$ colloque interrégional sur le Néolithique, Strasbourg, 27-29 octobre 1995. Cahiers de l'Association pour la promotion de la Recherche Archéologique en Alsace, supplément 3. Strasbourg: A.P.R.A.A., 401-405.

Weiner, J. 1998:

Neolithische Brunnen - Bemerkungen zur Terminologie, Typologie und Technologie mit einem Modell zur bandkeramischen Wasserversorgung. In: Koschik, H. /ed./: Brunnen der Jungsteinzeit. Internationales Symposium in Erkelenz, 27. bis 29. Oktober 1997. Materialen zur Bodendenkmalpflege im Rheinland 11. Köln: Rheinland-Verlag GmbH, 193-213. 
Weiner, J. 2016:

Kühl, klar und köstlich. Wasserversorgung und Brunnen im Neolithikum. In: Otten, T. - Kunow, J. - Rind, M. M. - Trier, M. /eds./: Revolution Jungsteinzeit. Archäologische Landesausstellung Nordrhein-Westfalen. Schriften zur Bodendenkmalpflege in Nordrhein-Westfalen 11/1. Darmstadt: Theiss, 156-169.

Weiner, J. - Lehmann, J. 1998:

Remarks Concerning Early Neolithic Woodworking: The Example of the Bandkeramic Well of Erkelenz-Kückhoven, NorthrhineWestfalia, Germany. In: Pessina, A. - Castelletti, L. /eds./: Introduzione all'archeologia degli spazi domestici. Archeologia dell'Italia Settentrionale 7. Como: Museo civico archeologico Giovio, 35-55.

Whitehouse, N. J. - Smith, D. 2010:

How fragmented was the British Holocene wildwood? Perspectives on the "Vera" grazing debate from the fossil beetle record. Quarternary Science Reviews 29, 539-553.

DOI: 0.1016/j.quascirev.2009.10.010.

Windl, H. J. 1998:

Der Brunnen der Linearbandkeramik von Schletz/Asparn a. d. Zaya, p. B. Mistelbach, im Nordosten Österreichs. In: Koschik, H. /ed./: Brunnen der Jungsteinzeit. Internationales Symposium in Erkelenz, 27. bis 29. Oktober 1997. Materialen zur Bodendenkmalpflege im Rheinland 11. Köln: Rheinland-Verlag GmbH, 85-93.

Willis, K. J. - Bennett, K. D. 1994:

The Neolithic transition - fact or fiction? Palaeoecological evidence from the Balkans. The Holocene 4/3, 326-330.

DOI: $10.1177 / 095968369400400313$.
Wollenweber, R. 2016:

One house like another? - Access to water wells as an indicator of social inequality in the Linear and Stroke-Ornamented Pottery Cultures. In: Meller, H. - Hahn, P. - Jung, R. - Risch, R. /eds./: Arm und Reich - Zur Ressourcenverteilung in prähistorischen Gesellschaften / Rich and Poor - Competing for resources in prehistoric societies. Tagungen des Landesmuseums für Vorgeschichte Halle 14/I. Halle: Landesamt für Denkmalpflege und Archäologie Sachsen-Anhalt - Landesmuseum für Vorgeschichte Halle, 165-180.

Wolters, S. - Bittmann, F. - Kummer, V. 2005:

The first subfossil records of Urtica kioviensis Rogow. and their consequences for palaeoecological interpretations. Vegetation History and Archaeobotany 14, 518-527.

DOI: $10.1007 / \mathrm{s} 00334-005-0084-9$.

Zerl, T. - Herbig, C. 2012:

„... bei dem kühlen Brunnenwasser ...“ Ein erster Vergleich archäobotanischer Makrorestspektren aus den linienbandkeramischen Brunnen von Erkelenz-Kückhoven (NordrheinWestfalen) und Brodau (Sachsen). In: Stobbe, A. - Tegtmeier, U. /eds./: Verzweigungen. Eine Würdigung für A. J. Kalis und J. Meurers-Balke. Bonn: Dr. Rudolf Habelt GmbH, 351-369.

Zimmermann, U. 2009:

Ein linearbandkeramischer Sickerbrunnen und andere bemerkenswerte Befunde in Würnitz. Fundberichte aus Österreich 48, 349-356. 
Mgr. Ivana Vostrovská, Ph.D., Department of History, Faculty of Arts, Palacký University Olomouc (Katedra historie, Filozofická fakulta Univerzity Palackého v Olomouci), Na Hradě 5, 77900 Olomouc, Czech Republic; e-mail: ivana.vostrovska@upol.cz

Mgr. Jan Petřík, Ph.D., Department of Geological Sciences, Faculty of Science, Masaryk University (Ústav geologických věd, Prírodovědecká fakulta Masarykovy university), Kotlářská 2, 61137 Brno, Czech Republic; e-mail: petrik.j@sci.muni.cz

Mgr. Libor Petr, Ph.D., Department of Botany and Zoology, Faculty of Science, Masaryk University (Ústav botaniky a zoologie, Prírodovědecká fakulta Masarykovy university), Kotlářská 2, 61137 Brno, Czech Republic; e-mail: petr.libor@gmail.com

Mgr. Petr Kočár, Institute of Archaeology of the Czech Academy of Sciences, Prague (Archeologický ústav AV ČR, Praha, v. v. i.), Letenská 4, 11801 Praha, Czech Republic; e-mail: kocar@arup.cas.cz

Mgr. Romana Kočárová, Department of Botany, Faculty of Science, Charles University (Katedra botaniky, Prírodovědecká fakulta Univerzity Karlovy), Benátská 433/2, 12801 Praha 2, Czech Republic; e-mail: rkocarova@seznam.cz

RNDr. Zbyněk Hradílek, Ph.D., Department of Botany, Faculty of Science, Palacký University Olomouc (Katedra botaniky, Prírodovědecká fakulta Univerzity Palackého v Olomouci), Šlechtitelů 27, 78371 Olomouc, Czech Republic: e-mail: zbynek.hradilek@upol.cz

Mgr. Josef Kašák, Ph.D., Department of Forest Protection and Wildlife Management, Faculty of Forestry and Wood Technology, Mendel University in Brno (Ústav ochrany lesů a myslivosti, Lesnická a dřevařská fakulta Mendelovy univerzity v Brně), Zemědělská 3, 61300 Brno, Czech Republic; e-mail: abovic@seznam.cz

Mgr. Zdeňka Sůvová, Czech Institute of Egyptology, Faculty of Arts, Charles University (Český egyptologický ústav, Filozofická fakulta Univerzity Karlovy), Celetná 20, 10000 Praha, Czech Republic; e-mail: suvovaz@ff.cuni.cz

Mgr. Katarína Adameková, Department of Geological Sciences, Faculty of Science, Masaryk University (Ústav geologických věd, Prírodovědecká fakulta Masarykovy university), Kotlářská 2, 61137 Brno, Czech Republic; e-mail: katu.adamekova@gmail.com

Mgr. Zdeněk Vaněček, Department of History, Faculty of Arts, Palacký University Olomouc (Katedra historie, Filozofická fakulta Univerzity Pa lackého v Olomouci), Na Hradě 5, 77900 Olomouc, Czech Republic; e-mail: zdenek.vanecek@gmail.com

Doc. PhDr. Jaroslav Peška, Ph.D., Archaeological Centre Olomouc (Archeologické centrum Olomouc), U Hradiska 6, 77900 Olomouc, Czech Republic; e-mail: peska@ac-olomouc.cz

Dr. Bernhard Muigg, Institute of Forest Sciences, University of Freiburg, Tennenbacher Str. 4, 79106 Freiburg, Germany; e-mail: bernhard.muigg@wfg.uni-freiburg.de

Doc. Ing. Michal Rybníček, Ph.D., Department of Wood Science and Technology, Faculty of Forestry and Wood Technology, Mendel University in Brno (Ústav nauky o dřevě a dřevařských technologií, Lesnická a dřevařská fakulta Mendelovy univerzity v Brně), Zemědělská 3, 613 00 Brno, Czech Republic; e-mail: michalryb@post.cz

Ing. Tomáš Koláŕ, Ph.D., Department of Wood Science and Technology, Faculty of Forestry and Wood Technology, Mendel University in Brno (Ústav nauky o dřevě a dřevařských technologií, Lesnická a dřevařská fakulta Mendelovy univerzity v Brně), Zemědělská 3, 61300 Brno, Czech Republic; e-mail: koldatom@gmail.com

Dr. rer. nat. Willy Tegel, Institute of Forest Sciences, University of Freiburg, Tennenbacher Str. 4, 79106 Freiburg, Germany; e-mail: tegel@dendro.de

Mgr. Marek Kalábek, Archaeological Centre Olomouc (Archeologické centrum Olomouc), U Hradiska 6, 779 00 Olomouc, Czech Republic; e-mail: kalabek@ac-olomouc.cz

Mgr. Pavlína Kalábková, Ph.D., Department of History, Faculty of Arts, Palacký University Olomouc (Katedra historie, Filozofická fakulta Univerzity Palackého v Olomouci), Na Hradě 5, 77900 Olomouc, Czech Republic; e-mail: pavlina.kalabkova@upol.cz 
